University of Louisville ThinkIR: The University of Louisville's Institutional Repository

Electronic Theses and Dissertations

$8-2016$

\title{
Air pollution, pulmonary oxidative stress, and the endothelin system in the development of cardiovascular injury.
}

Jordan B. Finch

University of Louisville

Follow this and additional works at: https://ir.library.louisville.edu/etd

Part of the Cardiovascular Diseases Commons, Environmental Health Commons, Environmental Public Health Commons, and the Toxicology Commons

\section{Recommended Citation}

Finch, Jordan B., "Air pollution, pulmonary oxidative stress, and the endothelin system in the development of cardiovascular injury." (2016). Electronic Theses and Dissertations. Paper 2520.

https://doi.org/10.18297/etd/2520

This Master's Thesis is brought to you for free and open access by ThinkIR: The University of Louisville's Institutional Repository. It has been accepted for inclusion in Electronic Theses and Dissertations by an authorized administrator of ThinkIR: The University of Louisville's Institutional Repository. This title appears here courtesy of the author, who has retained all other copyrights. For more information, please contact thinkir@louisville.edu. 


\title{
AIR POLLUTION, PULMONARY OXIDATIVE STRESS, AND THE ENDOTHELIN SYSTEM IN THE DEVELOPMENT OF CARDIOVASCULAR INJURY
}

\author{
By \\ Jordan B. Finch \\ B.S., McKendree University, 2011 \\ M.S., Southern Illinois University Edwardsville, 2013
}

\author{
A Thesis \\ Submitted to the Faculty of the \\ School of Medicine of the University of Louisville \\ In Partial Fulfillment of the Requirements \\ for the Degree of \\ Master of Science \\ in Pharmacology and Toxicology \\ Department of Pharmacology and Toxicology \\ University of Louisville \\ Louisville, KY
}

August 2016 
Copyright 2016 by Jordan Bailey Finch

All rights reserved 



\title{
AIR POLLUTION, PULMONARY OXIDATIVE STRESS, AND THE ENDOTHELIN SYSTEM IN THE DEVELOPMENT OF CARDIOVASCULAR INJURY
}

\author{
By \\ Jordan B. Finch \\ B.S., McKendree University, 2011 \\ M.S., Southern Illinois University Edwardsville, 2013 \\ Thesis Approved on
}

July 28, 2016

by the Following Thesis Committee:

Daniel J. Conklin, Ph.D.

Aruni Bhatnagar, Ph.D., F.A.H.A.

Gary W. Hoyle, Ph.D.

Steven R. Myers, Ph.D.

John P. Wise, Sr., Ph.D. 


\section{ACKNOWLEDGEMENTS}

I would like to thank my mentor, Daniel J. Conklin, Ph.D., for all his advice and direction over the past few years. I would also like to thank my committee members, Drs. Aruni Bhatnagar, Gary Hoyle, Steven Myers, and John Wise, Sr., for their insight and assistance. Additional thanks to Dr. C. Arden Pope III and Dr. Timothy O'Toole for allowing me to use their study samples and for their general assistance with the human portion of this project.

Many thanks also to my fellow lab mates for their help in learning my way around the lab and in learning how to perform a variety of techniques. In particular, I would like to thank Dr. Natasha DeJarnett and Dr. Ray Yeager for their encouragement and friendship throughout this entire process.

Finally, I would like to thank my parents, Kevin and Lisa Finch, and the rest of my family for their support and encouragement. I would never have made it this far without their willingness to walk beside me and push me to be my best, even if that meant having to listen to crazy work stories. 


\begin{abstract}
AIR POLLUTION, PULMONARY OXIDATIVE STRESS, AND THE ENDOTHELIN SYSTEM IN THE DEVELOPMENT OF CARDIOVASCULAR INJURY
\end{abstract}

Jordan B. Finch

July 28, 2016

The goal of this project was to examine the role of endothelin-1 (ET-1) as a mediator in the pathway between air pollution exposure and the development of vascular injury. A human cohort and male mice (C57BL/6 and ecSOD-Tg) were used to evaluate changes in the ET-1 system in response to exposures of fine particulate matter $\left(\mathrm{PM}_{2.5}\right)$. Human ET-1 levels were significantly associated with environmental factors and markers of vascular change, but were decreased with increased $\mathrm{PM}_{2.5}$. No association was seen between ET-1 and endothelial progenitor cells (EPCs) except for EPC-4, possibly indicating a regulatory relationship with this specific population. In mice, the expression of the ET-1 system in the cardiopulmonary tissues changed significantly with exposure, with changes varying between exposure conditions. A potentially protective effect was seen in the lungs of ecSOD-Tg animals. These data suggest that ET-1 plays an important role in the vascular response to $\mathrm{PM}_{2.5}$ exposure. 


\section{TABLE OF CONTENTS}

\section{PAGE}

ACKNOWLEDGEMENTS ........................................................

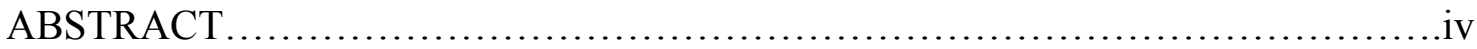

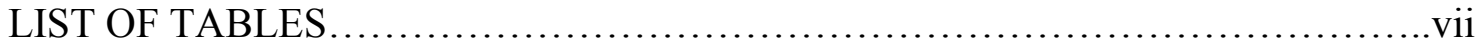

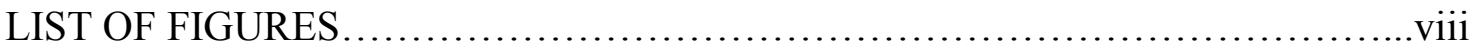

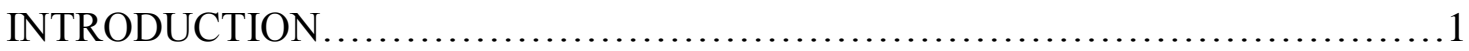

Air Pollution and Cardiovascular Disease................................2

The Endothelin System..............................................4

Endothelin-1 (ET-1).........................................4

ET-1 Receptors.............................................5

Physiology and Pathology of the Endothelin System..................

Air Pollution and Endothelin-1 ......................................... 9

Human Studies..............................................9

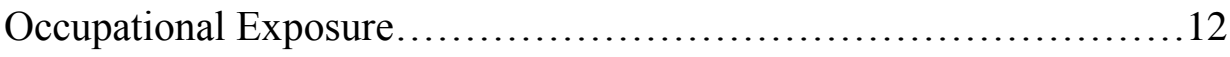

Animal Studies...............................................14

Endothelial Progenitor Cells (EPCs) and ET-1.......................... 15

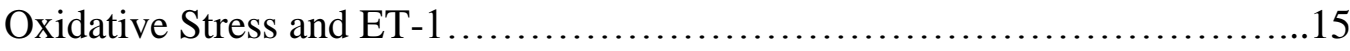

OBJECTIVES AND HYPOTHESIS..........................................17

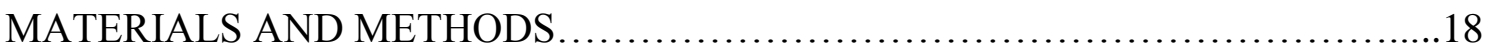

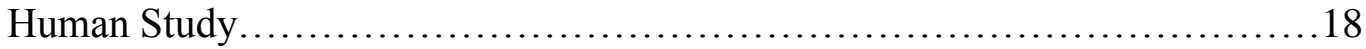


Animal Studies.....................................................21

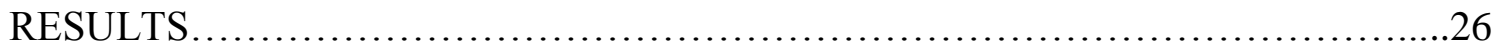

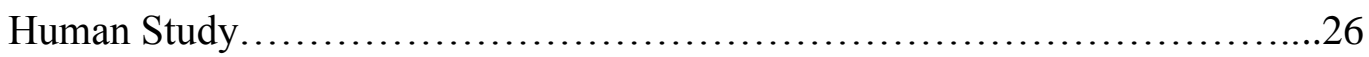

Animal Studies......................................................... 30

DISCUSSION AND CONCLUSIONS ....................................48

Human Study ...................................................48

Animal Studies....................................................55

Conclusions......................................................60

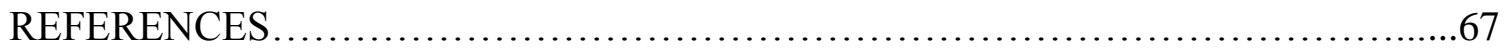

APPENDICES ............................................................. 82

Abbreviations....................................................... 82

Copyright Clearance................................................86

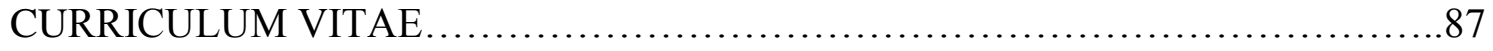




\section{LIST OF TABLES}

TABLE

PAGE

1. Antigenic identity of endothelial progenitor cells............................20

2. Demographic summary of the study participants stratified by median ET-1 .......27

3. Association between ET-1 levels and blood study variables......................28

4. Association between ET-1 and EPC levels.......................................

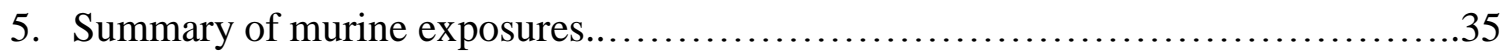




\section{LIST OF FIGURES}

FIGURE

PAGE

1. Schematic of vascular wall cell dependent production and receptor-mediated

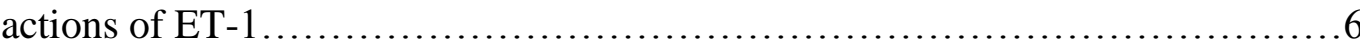

2. The versatile aerosol concentration enrichment system (VACES) .................23

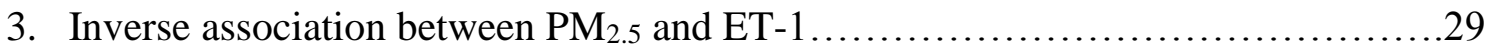

4. Association between $\mathrm{PM}_{2.5}$ and blood variables....................................31

5. No association between ET-1 and CD34 ${ }^{+} / 31^{+}$cells..............................33

6. Positive association between ET- 1 and $\mathrm{CD} 31^{+} / 34^{+} / 45^{+} / \mathrm{ACC} 133^{+}$cells..............34

7. Body weights of C57BL/6 mice before and after exposures.......................36

8. mRNA expression of C57BL/6 cardiopulmonary tissues after an acute, low

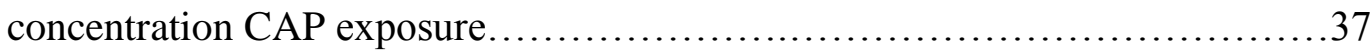

9. mRNA expression of C57BL/6 cardiopulmonary tissues after an acute, medium

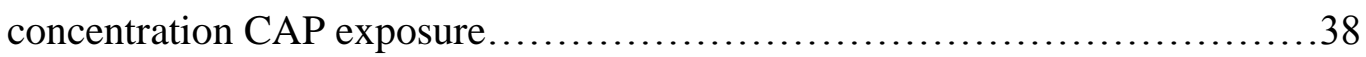

10. mRNA expression of ecSOD-Tg cardiopulmonary tissues after an acute, low

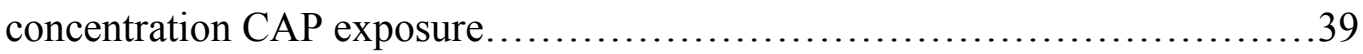

11. mRNA expression of C57BL/6 cardiopulmonary tissues after a chronic, medium concentration CAP exposure ....................................41

12. mRNA expression of ecSOD-Tg cardiopulmonary tissues after a chronic,

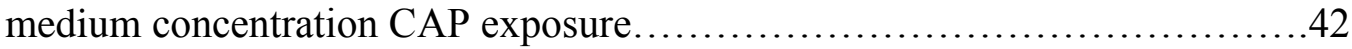


13. Comparison of mRNA expression of C57BL/6 cardiopulmonary tissues after acute low and medium concentration CAP exposures.........................43

14. Comparison of mRNA expression of C57BL/6 and ecSOD-Tg cardiopulmonary tissues after an acute, low concentration CAP exposure...................44

15. Comparison of mRNA expression of C57BL/6 cardiopulmonary tissues after acute and chronic medium concentration CAP exposures...................46

16. Comparison of mRNA expression of C57BL/6 and ecSOD-Tg cardiopulmonary tissues after a chronic, medium concentration CAP exposure 


\section{INTRODUCTION}

Air pollution is a complex mixture of gases, particulates, and other molecules that permeate the atmosphere, making exposure largely unavoidable in most indoor and outdoor settings. Outdoor, or ambient, pollution can be produced by exhaust from numerous sources, including motor vehicles, coal-fired power plants, industrial processes, agricultural dust, and smoke from biomass, structural, and wild fires. Incomplete fuel combustion from open fires (wood, coal, organic matter) and cooking stoves is the major source of indoor or household air pollution $(1,2)$. Sources of particulate matter (PM), such as cigarette smoke, can affect individuals in both indoor and outdoor locations. All sources of PM have the potential to impact human health, but while household pollution impacts individuals on a personal level, ambient pollution has the potential to influence global health. To address this issue, several countries have passed air quality laws designed to reduce air pollution through the regulation of a variety of specific air toxics. For example, in the United States, 187 air toxics, including acrolein, lead, and ozone $\left(\mathrm{O}_{3}\right)$, are regulated by the Clean Air Act passed in 1963 (3). Numerous other policies have been introduced to decrease annual pollution levels, and new technologies have been introduced that work to remove contaminants from smoke and other aerosols before these reach the atmosphere (4). These efforts led to a $49 \%$ decrease in aggregate emissions between 1980 and 2006 (5) and to an average $72 \%$ drop 
in emissions of the six most common pollutants: particles, ozone, lead, carbon monoxide, nitrogen dioxide, and sulfur dioxide (5).

Despite the concerted efforts, decreases in PM are not sufficiently effective enough to prevent pollution-induced impacts on human health. The World Health Organization (WHO) attributed 7 million premature fatalities in 2012 to exposure from ambient and indoor air pollution, which roughly equates to 1 in 8 global deaths (6). The WHO attributed the majority of these deaths to cardiovascular diseases (CVD), with 37\% and $33 \%$ due to stroke and ischemic heart disease, respectively. Other causes of death included respiratory conditions (24\%) and lung cancer (6\%) (6). In the United States, the Centers for Disease Control and Prevention (CDC) attributes an annual 600,000 American deaths to heart disease, emphasizing the significant burden of heart disease on a national level (7). Although air pollution has a low odds ratio for the increased risk of myocardial infarction (MI) (1.02; confidence interval 1.01-1.02), the $100 \%$ exposure rate significantly increases the percentage of MIs attributable to air pollution, with levels similar to physical exertion and alcohol (8). Although epidemiological studies well support an association between air pollution and CVD, this research is insufficient to elucidate the mechanisms responsible, and thus, more research is required in order to ultimately improve pollution-related health outcomes. Based on the health and financial burden of CVD, it is necessary from medical, legislative, and economic standpoints to continue working towards decreased air pollution emissions in an effort to collectively reduce morbidity and mortality and to reveal the biological mechanism(s) by which air pollution causes and/or exacerbates CVD.

AIR POLLUTION AND CARDIOVASCULAR DISEASE 
Over the past 20 years, a number of clinical and epidemiological studies have established the damaging effects of air pollution on human health. The majority of this damage is found in the pulmonary and cardiovascular systems, leading to an increased risk of heart disease or stroke. Many of these health effects are linked to different forms of air pollution, including ambient air pollution and diesel (DE) and gasoline engine exhausts (GEE). Ambient air pollution is composed of a gaseous suspension of aerosolized particles that typically have an aerodynamic diameter $<10 \mu \mathrm{m}(9,10)$; this range is classified into specific particle sizes: ultrafine $(<0.1 \mu \mathrm{m})$, fine $\left(\mathrm{PM}_{2.5}, 0.1-2.5\right.$ $\mu \mathrm{m})$, and coarse $\left(\mathrm{PM}_{10},>2.5-10 \mu \mathrm{m}\right)$. There is strong evidence linking increased levels of $\mathrm{PM}_{2.5}$ with increased cardiovascular effects $(9,11,12)$. A $10 \mu \mathrm{g} / \mathrm{m}^{3}$ increase in $\mathrm{PM}_{2.5}$ levels is associated with an increased risk of heart failure hospitalization (13) and with long-term all-cause mortality (14-18).

Additional studies of specific types of air pollutants further strengthen the link between exposure and cardiovascular events. $\mathrm{PM}_{2.5}$ exposure significantly increases left ventricular mass (19) and systolic (20-22) and mean ambulatory arterial (23) blood pressures. Changes in $\mathrm{PM}_{2.5}$ are associated with the onset of MIs (24) and increased intima media thickness progression $(25,26)$, with accelerated carotid intima media thickness (CIMT) progression of up to $5.5 \mu \mathrm{m}$ (per $10 \mathrm{ug} / \mathrm{m}^{3}$ ) per year (27). Similarly, exposure to diesel exhaust and traffic-related pollution increases arterial stiffness (28) and systolic blood pressure (29) and is associated with both increased mortality hazard ratio and increased risk of dying after hospital discharge (30). Collectively, these pathogenic changes (e.g., increased CIMT, increased blood pressure) suggest that an 
underlying vascular alteration or dysfunction is responsible, and thus, there is a need to explore mechanisms consistent with these vascular manifestations.

Brook et al. (12) propose three likely mechanisms by which air pollution may contribute to the development of CVD: 1) an imbalance in the autonomic nervous system; 2) translocation of particles, specifically ultrafine PM, into the circulation; and, 3) the development of systemic oxidative stress and inflammation within the vasculature. These hypothetical pathways are generally accepted (11, 23, 28, 31-36). A primary outcome of these mechanisms is the initiation of endothelium dysfunction, which appears central (perhaps as a result of or in combination with oxidative stress and inflammation) to further development of CVD. Evidence suggests a strong association between endothelium dysfunction and cardiovascular events, leading to high morbidity and mortality from CVD (37) as well as other disease states (38-43). Endothelium dysfunction is characterized by an imbalance between the dilator and constrictor forces in the vasculature. This is best exemplified by concurrent decreased formation and bioactivity of nitric oxide (NO, derived from endothelial nitric oxide synthase, eNOS) and increased levels or activity of the endothelium-derived vasoconstrictor peptide endothelin-1 (ET-1) (37).

THE ENDOTHELIN SYSTEM

Endothelin-1 (ET-1)

Research in the early 1980 s led to the chemical identification of the endotheliumderived relaxant factor NO that is recognized as one of the most important factors in regulating vascular smooth muscle tone $(44,45)$. Soon after, it became obvious that the 
endothelium also produces a vasoconstrictor to counteract NO's effect and maintain vascular homeostasis. Yanagisawa and colleagues isolated and sequenced the gene for a vasoconstrictive endothelin peptide (46); two more isoforms were later discovered, and the peptide sequenced by Yanagisawa was termed endothelin-1 (ET-1), with the subsequent peptides named endothelin-2 (ET-2) and -3 (ET-3) (47-52). A fourth isoform has since been discovered, but evidence suggests that this peptide serves solely as an intestinal smooth muscle constrictor $(50,53,54)$. Of these four, ET-1 is the predominant isoform, and it exerts the greatest vasoconstrictive effect $(50,52,55)$. ET-1 is a 21amino acid peptide formed by the cleavage of pro-ET-1 (aka big ET-1) by the endothelial cell-specific endothelin-converting enzyme, ECE-1, into the active form $(46,50,52,55$, 56) (Figure 1). As expected, the endothelium is the most common source of ET-1 production, but the peptide may also be produced by vascular smooth muscle cells, cardiomyocytes, macrophages, leukocytes, and fibroblasts $(48,55,57)$. A number of physical and chemical factors upregulate the expression of the ET-1 gene: reactive oxygen species (ROS) (58), angiotensin II (49, 55, 57-59), cytokines $(57,59)$, tumor necrosis factor-alpha $(\mathrm{TNF} \alpha)(55,58)$, interleukins $(55,58)$, insulin $(49,55)$, norepinephrine (55), transforming growth factor-beta (TGF $\beta)(49,55,58-60)$, thrombin $(49,55,57,58,61)$, and exposure to cold temperature (62). Despite the number of factors that have the potential to increase ET-1 production, the physiological range of plasma ET-1 levels in a healthy individual is both relatively low (pg/ml) and narrow, emphasizing the tight homeostatic regulation of this potent peptide $(48,58,59,63)$.

\section{ET-1 Receptors}

Once secreted, ET-1 binds to one of its two G-protein-coupled receptor types to 


\section{Figure 1}

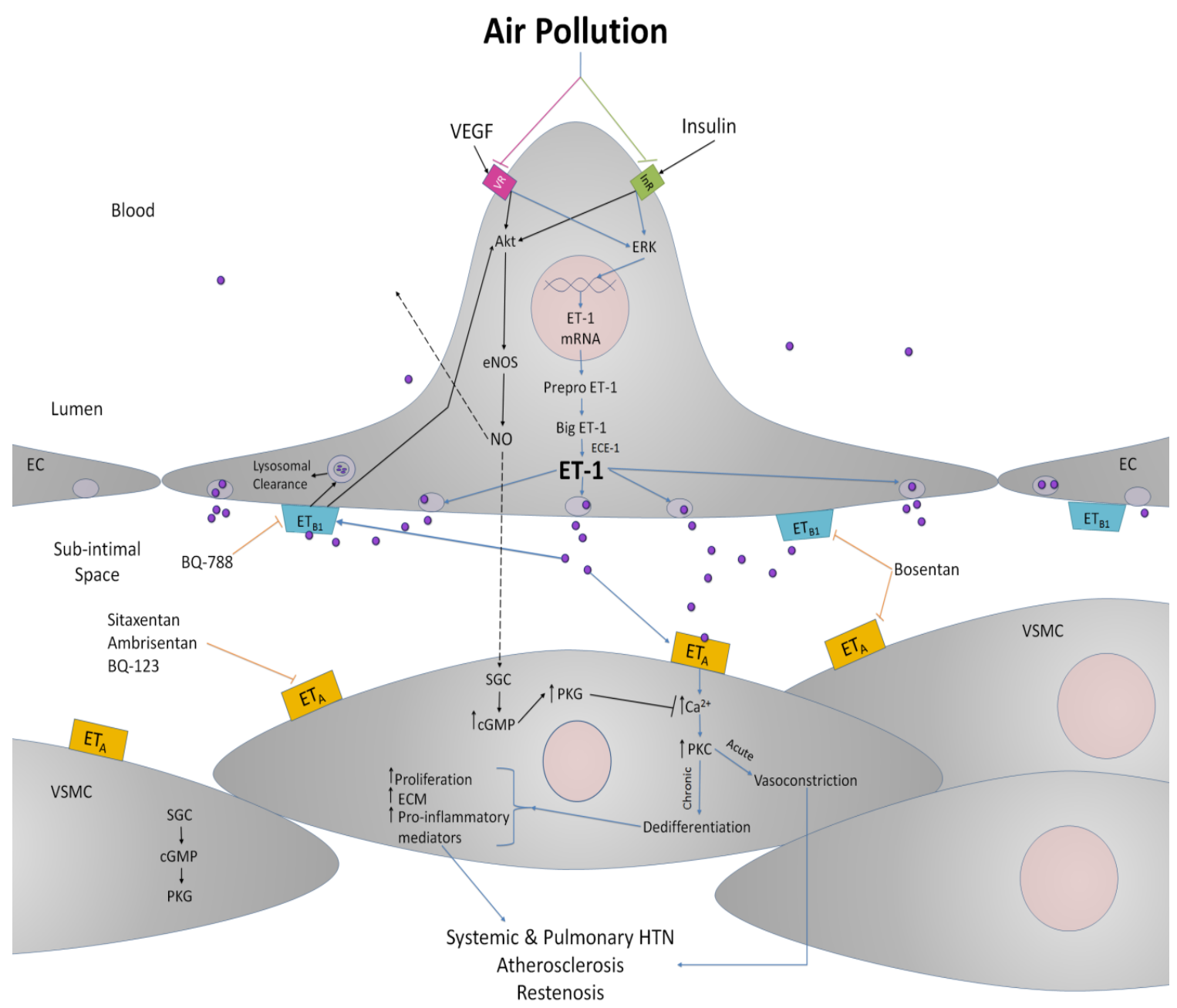

Figure 1: Schematic of vascular wall cell dependent production and receptor-mediated

actions of ET-1. ET-1 is produced through a series of precursors in response to

stimulating signals. Abluminally-released ET-1 binds to either the $\mathrm{ET}_{\mathrm{A}}$ or $\mathrm{ET}_{\mathrm{B}}$ receptor.

Binding to the $\mathrm{ET}_{\mathrm{A}}$ receptor causes vasoconstriction and may lead to increases in blood pressure. Chronic activation of this receptor can lead to hypertension or atherosclerosis.

Binding to the $\mathrm{ET}_{\mathrm{B}}$ receptor leads to clearance of ET-1 from the vasculature and to the production of nitric oxide. ET-1 and nitric oxide homeostatically balance with one another to maintain basal vascular tone. 
mediate its downstream effects $(57,64,65)$. The $\mathrm{ET}_{\mathrm{A}}$ receptor, found on vascular smooth muscle cells and cardiomyocytes, mediates a contractile response, while the $\mathrm{ET}_{\mathrm{B}}$ receptor, found on vascular endothelial, epithelial, endocrine, and nerve cells, generally causes the release of vasodilators and is also responsible for the rapid clearance of ET-1 from the vasculature $(57,64-67)$. Binding to the $\mathrm{ET}_{\mathrm{B}}$ receptor also stimulates the protein kinase B (Akt) pathway, leading to phosphorylation of eNOS and production of NO (57, 64). As expected, these receptors are distributed in high levels throughout the vasculature, and although the $\mathrm{ET}_{\mathrm{A}}$ receptor is found in higher levels in the heart, the $\mathrm{ET}_{\mathrm{B}}$ receptor has a greater distribution in the lungs and kidneys $(55,63,68,69)$. A subtype of the $\mathrm{ET}_{\mathrm{B}}$ receptor, $\mathrm{ET}_{\mathrm{B} 2}$, also causes vasoconstriction, but it is not found widely throughout the vasculature, and its activity is negligible in healthy individuals $(55,59$, 70). Upon binding to the $\mathrm{ET}_{\mathrm{A}}$ receptor, ET-1 produces a vasoconstrictive response that is 100-times more potent than norepinephrine, thus making it the most potent vasoconstrictor known $(52,71)$. ET-1-mediated vasoconstriction decreases forearm blood flow and causes a significant increase in blood pressure (72-76); prolonged ET-1induced constriction facilitates the development of hypertension $(21,77,78)$ and promotes atherosclerosis $(48,49,52,55,79-81)$. ET-1, however, under normal conditions, maintains vascular tone $(65,82)$ in balance with NO. Moreover, ET-1 is necessary for proper skeletal development of the head and neck (83-85) and the formation of the vasculature in and around the heart (86), as well as control of embryonic heart rate (87).

Physiology and Pathology of the Endothelin System 
Like all homeostatic mechanisms in the body, the interaction between ET-1 and NO must be in balance in order for the vascular system to function properly, and it is when these two factors become unbalanced that pathological states such as endothelium dysfunction can begin to develop. Although endothelium dysfunction is commonly assessed as a decrease in NO production, it can be caused by an increase in ET-1 production $(50,52,79)$. Nonetheless, it is important to consider that increased ET-1 activity could also be caused by decreased ET-1 clearance and/or by lower levels of NO production or stability (79). Decreased NO in the vasculature allows a greater effect of ET-1 independent of any change in ET-1 levels. Regardless of the cause, many studies, including a number of pharmacological trials, show ET-1-dependent activity initiates pleiotropic effects beyond only vasoconstriction. ET-1, working through a variety of pathways, generates ROS (88-90) such as superoxide $(48,79,81,89-91)$; activates macrophages, leading to increased production of pro-inflammatory mediators $(65,79-81$, 90, 92-94); induces extracellular matrix formation (95); and stimulates vascular smooth muscle cell proliferation $(48,59,81,88,95,96)$. Furthermore, increased ET-1 inhibits eNOS and blocks the production of NO $(79,96)$. These actions can disrupt the equilibrium within the vascular wall and initiate endothelium dysfunction $(12,32,81,90$, 97-100), and thereby, generally promote the development of CVD. Therefore, it is plausible and likely that altered ET-1 production and/or activity is one mechanism by which air pollution enhances the development of vascular dysfunction (40, 41, 76-79, 100).

The endothelin system is spread along 60,000 miles of vasculature in the body, so it is within reason that dysregulation of ET-1 could have effects in multiple organ 
systems and potentially augment the development of other diseases. As with CVD, the vasoconstrictive effect of ET-1 is the proposed major cause of these conditions. In the extremities, cold-temperature-induced increases in ET-1 contribute to the pathogenesis of Raynaud's phenomenon $(38,101)$, in which exaggerated vasoconstriction causes discomfort (ischemic pain) and discoloration of the affected areas. Likewise, ET-1related vascular dysfunction in the eye leads to intraocular inflammation; this plays an important part in the development of primary open-angle glaucoma (42). In the kidneys, ET-1 controls renal blood flow and the reabsorption of water and salt, as well as maintains acid-base balance $(55,58,79,102)$. If any of these factors are disrupted, it can result in the development of hypertensive neuropathy, glomerulonephritis, or proteinuria $(58,80)$. Within the pulmonary system, ET-1 is produced both by endothelial cells and by airway epithelial cells and cleared by the high levels of the $\mathrm{ET}_{\mathrm{B}}$ receptor found in the pulmonary tissue $(55,63,68,69)$. ET-1 influences the maintenance of airway tone, and so increased production or decreased clearance may lead to bronchial constriction $(55$, 103). Chronic bronchial constriction can promote asthma and chronic obstructive pulmonary disease (COPD) $(39,104-106)$. ET-1 also affects the arteries and veins in the lungs, and thus, elevated ET-1 can lead to the development of pulmonary hypertension, just as it can stimulate the development of systemic hypertension $(98,107,108)$. Thus, changes in ET-1 or its activity can be a link between exposure to air pollution and the development of a variety of pathogenic states through the induction of vasoconstriction and endothelium dysfunction as prevalently seen in CVD.

AIR POLLUTION AND ENDOTHELIN-1

\section{Human Studies}


Despite the wealth of evidence described above, few studies have examined the relationship between air pollution exposure and circulating levels of ET-1 in humans, and those studies that have been performed have produced conflicting results. In epidemiological studies, Calderon-Garciduenas and colleagues have repeatedly examined the effects of elevated levels of air pollution on children in Mexico City, which has been shown to significantly exceed the WHO's annual mean $\mathrm{PM}_{2.5}$ standard $(109,110)$. In a 2007 study, the group measured plasma ET-1 levels in healthy children $(n=81)$ from both Mexico City and Polotitlán, a control city. They observed that the cumulative $\mathrm{PM}_{2.5}$ level of the previous 7-days was associated with higher plasma ET-1 levels in the children of Mexico City (109). Similarly, there was a positive correlation between the number of hours a child spent outdoors and plasma ET-1 level (109). The authors suggested that the time spent outside increased each child's exposure to air pollution that, in turn, increased plasma ET-1. In a related study, clinically healthy children $(\mathrm{n}=28)$ from Mexico City and Polotitlán were used to investigate the effect of $\mathrm{PM}_{2.5}$ on markers of systemic inflammation and endothelial cell injury. Again, Mexico City children were shown to have significantly higher levels of ET-1 and various inflammatory markers positively associated with elevated levels of $\mathrm{PM}_{2.5}$ exposure (111). Controlled human exposures have been performed to substantiate the findings of these few epidemiological studies and to provide a better understanding as to whether air pollution alters ET-1. A small study exposed healthy adults $(\mathrm{n}=10)$ to diesel exhaust $\left(100 \mu \mathrm{g} / \mathrm{m}^{3}\right)$ and showed that $\mathrm{DE}$ significantly increases plasma ET-1 and matrix metalloproteinase-9 (MMP-9) compared with filtered air-exposed controls (112). Dysregulation of MMP-9 contributes to 
pathological changes in the vasculature, and MMP-9 levels are increased via $\mathrm{ET}_{\mathrm{A}}$ receptor activation (112).

Other studies, however, have found no change in the ET-1 system related to air pollution exposure or no alteration in the functional outcomes related to ET-1-induced vasoconstriction. Peretz et al. (113) exposed a mixed group of both healthy subjects and people with metabolic syndrome to 2 hours of DE. They reported an average $0.11-\mathrm{mm}$ greater vasoconstriction in the brachial artery in the DE exposure group regardless of health status. Likewise, plasma levels of ET-1 increased in both groups following DE exposure and to a greater degree within the healthy adults. The authors attributed this latter finding to the arterial stiffness associated with metabolic syndrome; the vessels in the diseased individuals are less responsive to the effects of DE due to decreased plasticity, whereas the vessels of the healthy individuals are capable of producing a normal vascular response, and thus, could mount a greater range of vasoconstriction. DE exposure, however, did not affect blood pressure or flow-mediated dilatation (FMD), the latter being a common indicator of endothelium function. Similarly, after a 2 hour exposure to concentrated ambient air particulate matter (CAP), healthy non-smokers had no change in either FMD or in blood pressure, although they did have a significant reduction in brachial artery diameter (114). Both Mills et al. (115) and Langrish et al. (116) exposed participants to higher levels of DE-derived $\mathrm{PM}_{2.5}$, which was expected to have a greater effect on the endothelium, but neither investigation demonstrated any change in the plasma levels of ET-1 or big ET-1. The varied results of these human exposure studies indicate that the effect of air pollution exposure on the ET-1 system is 
difficult to measure and may differ based on factors such as pollution type, the length and concentration of exposure, and each measurement protocol.

Other research has focused on the targets of ET-1 - the ET-1 receptors. For example, administration of the selective $\mathrm{ET}_{\mathrm{A}}$ receptor antagonist, $\mathrm{BQ}-123$, is used to explore the possibility of an increased secretion of ET-1 abluminally, which would not necessarily change ET-1 levels in the plasma $(49,116)$. Exposure to DE decreased the amount of vasodilation seen as a result of the BQ-123 infusion, yet previous research indicated that BQ-123-induced vasodilation was in part due to endothelial cell-derived NO release mediated by the $\mathrm{ET}_{\mathrm{B}}$ receptor (117). Thus, Langrish et al. (116) proposed that DE-elicited vasoconstriction results from decreased NO bioavailability and not increased ET-1. Because NO and ET-1 must be delicately balanced in order to properly maintain the tone of the vasculature, a decrease in NO likely produces a similar effect as an increase in ET-1, so this remains a difficult relationship to disentangle. Further use of ET receptor blockers and observation of the effects of direct ET-1 administration should allow for elucidation of which of these two factors more significantly influences alterations within the vasculature.

\section{Occupational Exposure}

Occupational exposures often result in unique forms of personal air pollution exposure. A few studies have examined the cardiovascular effects of occupational traffic pollutant exposure $(104,118)$. A large study of professional drivers $(n=1,922)$ revealed that bus drivers who had more than 10 years' experience, theoretically with more engine exhaust exposure, had a two-fold increased odds-ratio of myocardial infarction, even 
after adjustment for unfavorable lifestyle factors; taxi drivers also had an increased odds ratio, while there was no evidence of increased risk for truck drivers (118). In another study, air-quality monitors were used to measure personal and ambient exposure of North Carolina State Highway Patrol troopers during four successive 9-hour shifts (104). Although the report indicates lower in-vehicle $\mathrm{PM}_{2.5}$ levels compared with ambient $\mathrm{PM}_{2.5}$, higher levels of other pollutants, including carbon monoxide, nitrogen dioxide, and hydrocarbons, were present in the vehicle. Furthermore, they showed that for every $10 \mu \mathrm{g} / \mathrm{m}^{3}$ increase in $\mathrm{PM}_{2.5}$, the officers exhibited increased C-reactive protein (hsCRP), which serves as an indicator of inflammation, and increased next-morning heart rate variability (HRV). HRV, like ET-1, has been shown to be altered by increased $\mathrm{PM}_{2.5}$, which indicates a relationship, either direct or indirect, between these two factors (20).

Workers in other occupations are also prone to high-level exposures of pollution. In a study of sugarcane harvesters, higher levels of $\mathrm{PM}_{2.5}$ are measured during the harvest season (119). Sugarcane fields are cleared by burning, and workers are exposed to high amounts of smoke and pollutants during burning and subsequently in the harvesting of the burnt sugarcane. Both systolic and diastolic blood pressures are significantly increased in the workers during the harvest season compared with the non-harvest period (119). Welding is another profession wherein workers are exposed to higher amounts of air pollution (120). However, Jarvela et al. (121) determined that an $8 \mathrm{~h}$ dust and welding fume exposure (inhalable dust; $1.5-35 \mathrm{mg} / \mathrm{m}^{3}$ ) did not significantly change the workers' levels of plasma ET-1, yet exposure to welding fumes (alveolar particle fraction; 1.0-25.3 $\mathrm{mg} / \mathrm{m}^{3}$ ) significantly decreased ET-1 (122). The investigators hypothesized that this contradictory response could be due to the heterogeneous mix of the welding fumes, 
which included high levels of nitrogen oxides that could disrupt the homeostasis in the vasculature. Regardless, the study had insufficient evidence to accurately describe the mechanism of the response (122), and so further research is needed to determine the cause of this somewhat paradoxical result.

\section{Animal Studies}

Both environmental and controlled exposures in animals show a consistent trend between air pollution and alterations in ET-1 levels. Mice exposed to GEE or DE have significant increases in plasma ET-1 (123), ET-1 mRNA expression in the aorta (105, 123), and ET-1-induced vasoconstriction (124). Some studies also noted elevated plasma levels of MMPs $(105,112,123)$, which, as noted, are upregulated via activation of the $\mathrm{ET}_{\mathrm{A}}$ receptor (112). Similarly, air pollution exposures in rats induced effects consistent with those observed in exposed mice. For example, exposure of rats to DE enhances both the arterial vasoconstriction response to ET-1 (125) and the expression of ET-1 and ETA receptor mRNAs (126). A combination exposure of DE particles and ozone also increases the expression of the $\mathrm{ET}_{\mathrm{B}}$ receptor in the aorta (126). Similarly, CAP exposure in rats upregulates the mRNA expression of the $\mathrm{ET}_{\mathrm{A}}$ receptor in the heart (127), and inhalation of urban dust particles increases plasma ET-1 level and decreases the production of pulmonary $\mathrm{NO}(128)$. In rabbits, $\mathrm{PM}_{10}$ exposure significantly increases plasma ET-1 level (129). Thus, in a number of different animal models, well-designed exposure experiments provide evidence that a variety of air pollutants (e.g., PM, PM + $\mathrm{O}_{3}, \mathrm{DE}, \mathrm{GEE}$ ) are capable of increasing the level of plasma ET-1 and/or enhancing its receptors in the vasculature while decreasing NO status. These changes likely prime blood vessels for endothelium and vascular dysfunction. 
ENDOTHELIAL PROGENITOR CELLS (EPCS) AND ET-1

ET-1-induced changes to the endothelium are likely to lead to vascular injury.

Prime markers of this injury are endothelial progenitor cells (EPCs). EPCs are stem cells produced by the bone marrow in response to vascular injury. Once activated, these cells differentiate into new endothelial cells to replace damaged cells in the vasculature (130). Exposure to $\mathrm{PM}_{2.5}$ has been shown to deplete circulating levels of EPCs in humans (131) and mice (132), the latter study indicating a mechanism related to vascular endothelial growth factor (VEGF) resistance; both studies suggest lower EPCs reduce vascular repair. Similar EPC and VEGF resistance effects were found in mice exposed acutely to acrolein (133), although ET-1 was not measured. Studies with tyrosine kinase inhibitors have shown that inhibition of the VEGF receptor stimulates the extracellular signalregulated kinase (ERK) pathway, increasing the expression of prepro-ET-1 while also inhibiting the Akt pathway and decreasing NO production (134-137). These results strengthen the hypothesis that VEGF resistance is a key component in the mechanism through which air pollution influences ET-1 and, downstream, EPCs. A small number of studies have looked at ET-1 and EPCs in relation to ischemic stroke (130), diabetes (138), and cancer (139), but none of these studies have been specifically designed to relate ET-1 and EPCs with air pollution. Further research is needed to clarify the role of ET-1 in the release of EPCs from the bone marrow and the interaction between these two factors within in the vasculature.

\section{OXIDATIVE STRESS AND ET-1}

As previously mentioned, ET-1 gene expression has been shown to be upregulated by ROS (58). Studies utilizing xanthine oxidase and hydrogen peroxide have 
demonstrated the ability of ROS to increase the expression and/or production of both ET1 and its precursors in human umbilical vein endothelial cells (HUVEC) (140), vascular smooth muscle cells $(141,142)$, human mesangial cells (143), and diabetic rat glomeruli, both in vitro and in vivo (144). This increase in ET-1 explains the link between increased levels of oxidative stress (OS) and incidence of increased vasoconstriction (140, 142, 143). Furthermore, these increases have been linked to the development of disease states such as diabetes $(144,145)$, hypertension (140), atherosclerosis $(140,145)$, and ischemia/reperfusion injury $(143,145)$. In attempts to better understand the underlying mechanisms of these diseases, it was discovered that the use of antioxidants could be used to ameliorate symptoms; as expected, ROS scavengers decreased ROS levels, which in turn prevented increased production of ET-1, allowing the vasoactive factors to remain balanced and preventing negative downstream effects. In particular, superoxide dismutase (SOD) and catalase have been shown to significantly decrease ET-1 production (144). Mice either under- or over-expressing levels of SOD have been used to evaluate OS under a number of different conditions (146-149), but no studies to date have used these mice to examine the relationship between OS and ET-1 after air pollution exposure. As air pollution has been shown to increase levels of OS and alter components of the ET-1 system, such exploration would be relevant to assess the impact of increased antioxidant levels on the vascular impact of $\mathrm{PM}_{2.5}$ exposure. 


\section{OBJECTIVES AND HYPOTHESES}

This study was designed to examine the role of ET-1 as a mediator in the pathway between $\mathrm{PM}_{2.5}$ exposure and the development of endothelium dysfunction and vascular injury. A young healthy human cohort and a mouse model were used to evaluate changes in the ET-1 system under varying $\mathrm{PM}_{2.5}$ exposure conditions. These studies test the following hypotheses:

1. Exposure to $\mathrm{PM}_{2.5}$ will increase levels of the ET-1 system components in human plasma and various mouse tissues.

2. $\mathrm{PM}_{2.5}$-induced changes in EPC levels will be associated with concurrent changes in ET-1 levels.

3. PM-induced ROS contributes to cardiopulmonary dysfunction by altering the ET-1 system. Thus, upregulation (or overexpression) of extracellular SOD (ecSOD) selectively in the lungs will attenuate extracellular ROS and prevent ROS-dependent injury and systemic changes. 


\section{MATERIALS AND METHODS}

\section{HUMAN STUDY}

This study was designed as a case-crossover study. Young, healthy nonsmokers ( 8 males and 8 females) were recruited from the Provo, Utah area between January and March of 2009 (131). All study consent forms and research protocols were approved through the Institutional Review Board for human subjects at Brigham Young University and through the Institutional Review Board at the University of Louisville. Exclusion criteria included: (1) not 18-30 years of age; (2) active smoking; (3) unwilling to participate and/or sign the consent forms; (4) body weight of less than 110 pounds; (5) health problems that would preclude participation, including but not limited to lack of two healthy arms, any known chronic pulmonary or cardiac disease, current infectious illness, chronic renal failure, Parkinsonism, alcohol abuse, mental illness, bleeding disorders, current pregnancy, past or current history of hepatitis, AIDS, or HIV; and, (6) currently living, working, or attending school with exposure to environmental tobacco smoke. Patients who met the enrollment criteria answered a questionnaire to obtain demographic information and baseline characteristics.

Daily $\mathrm{PM}_{2.5}$ monitoring was conducted by the State of Utah Division of Air Quality at two sites located in the Utah Valley. 24-hour monitoring was conducted at both the North Provo site and the Lindon Elementary site according to the U.S. Environmental Protection Agency's federal reference method (150). Tapered element 
oscillating microbalance (TEOM) monitors were also used to measure real-time $\mathrm{PM}_{2.5}$ mass concentrations. Additional weather parameters were collected from the National Weather Service using data reported from the Salt Lake City International Airport.

The whole Utah Valley region, including Provo, Utah, is subject to winter temperature inversions that cause the development of a stagnant air mass over the valley floor. $\mathrm{PM}_{2.5}$ and other emissions become trapped, and residents are exposed to high levels of pollution (151). Blood collections were coordinated to occur before, during and after an inversion period. The subjects underwent four blood draws: one during a high pollution period $\left(\mathrm{PM}_{2.5}>40 \mu \mathrm{g} / \mathrm{m}^{3}\right)$, one during a moderate level $\left(\mathrm{PM}_{2.5} \approx 20\right.$ to $\left.40 \mu \mathrm{g} / \mathrm{m}^{3}\right)$, and two draws during low pollution $\left(\mathrm{PM}_{2.5}<10 \mu \mathrm{g} / \mathrm{m}^{3}\right)$; the draws during low pollution served to establish baseline levels. Blood was collected at Brigham Young University by venipuncture at approximately the same time on each collection day. Approximately 20 $\mathrm{mL}$ of blood was collected in three separate tubes: a Vacutainer® CPT Mononuclear Cell Preparation Tube (Becton Dickinson) for EPC analysis, a Vacutainer® Plus PST ${ }^{\mathrm{TM}}$ plasma separator tube for analysis of plasma components, and a Vacutainer ${ }^{\circledR}$ whole blood ACD tube for platelet-monocyte aggregate analysis.

The analysis of serum components and EPC identification from these blood samples has been previously published, both as it was first described (152) and as it was modified by O'Toole et al. (131). In short, blood samples were collected and processed at Brigham Young University before being shipped overnight to the University of Louisville for analysis (131). EPCs and hematopoietic cell populations were characterized by 7-color flow cytometry using previously established markers (131). In all, six different cell types were identified and used for this study (Table 1). A Cobas 
Table 1

\begin{tabular}{|c|c|}
\hline Endothelial Progenitor Cell Population & Cell Differentiation Status \\
\hline Cell type-1 & $\mathrm{EPC} 31^{+} / 34^{+} / 45^{\mathrm{dim}}$ \\
\hline Cell type-2 & $\mathrm{EPC} 31^{+} / 34^{+} / 45^{+}$ \\
\hline Cell type-3 & $\mathrm{EPC} 31^{+} / 34^{+} / 45^{\mathrm{dim}} / \mathrm{AC} 133^{+}$ \\
\hline Cell type-4 & $\mathrm{EPC} 31^{+} / 34^{+} / 45^{+} / \mathrm{AC} 33^{+}$ \\
\hline Cell type-5 & $\mathrm{EPC} 31^{+} / \mathrm{AC} 33^{+}$ \\
\hline Cell type- 6 & $\mathrm{EPC} 31^{+} / 34^{+}$ \\
\hline
\end{tabular}

Table 1: Antigenic identity of endothelial progenitor cells. Six unique populations of endothelial progenitor cells were measured in blood samples of healthy young adults in response to $\mathrm{PM}_{2.5}$ exposure. 
Mira 5600 Autoanalyzer was used to measure fibrinogen, $\mathrm{C}$ reactive protein, cholesterol, high density lipoprotein, low density lipoprotein, triglycerides, albumin, and total plasma protein. ELISA kits were used to quantify serum amyloid A (Invitrogen), endothelin-1, interleukin 6 , interleukin $1 \beta$, VEGF, stromal cell-derived factor-1, and platelet factor 4 (R\&D Systems). Platelet-monocyte aggregates $\left(\mathrm{CD} 41^{+} / 45^{+}\right)$were measured using a double-positive gating FACS strategy.

Population demographics, environmental factors, and blood parameters between low $(\mathrm{ET}-1 \leq 0.6881 \mathrm{pg} / \mathrm{mL})$ and high $(\mathrm{ET}-1>0.6881 \mathrm{pg} / \mathrm{mL})$ levels of ET-1 were compared using one-way ANOVA and t-tests. Demographic variables that were found to be non-normally distributed were logarithmically transformed. Generalized linear modeling was used to determine an association between ET-1 and plasma components of interest, with adjustments for subject-specific fixed effects: gender, age, and $\mathrm{PM}_{2.5}$ (average of 24 hours before blood draw). EPC levels were log transformed for normality and normalized to the sample volume. Associations between ET-1 and EPC levels were assessed using linear regressions. Statistical significance was assumed at $p<0.05$. IBM SPSS Statistics Version 21.0 for Windows (Armonk, NY) and Microsoft Excel 2010 (Redmond, WA) were used for statistical analyses.

\section{ANIMAL STUDIES}

Because plasma levels of ET-1 may not reflect local changes in the ET-1 system, PM-induced changes in mouse tissues were also examined. All mice were maintained under standard laboratory conditions and treated humanely following protocols approved by the University of Louisville Institutional Animal Care and Use Committee. Male 
C57BL/6 mice and mice overexpressing lung-specific ecSOD (ecSOD-Tg) were exposed to either high-efficiency particulate air (HEPA)-filtered air or to $\mathrm{PM}_{2.5}$ concentrated from ambient downtown Louisville air for six hours a day for either 9 or 30 consecutive days. Ambient $\mathrm{PM}_{2.5}$ was concentrated (CAP) via a modified versatile aerosol concentration enrichment system (VACES) (153) located in the University of Louisville Inhalation Facility (Figure 2). $\mathrm{PM}_{2.5}$ was separated out of ambient air drawn in through an externally-mounted high volume exhaust pump via a cyclone generator. Particles were passed through a heated, humidified stainless steel chamber (approximately $28-30{ }^{\circ} \mathrm{C}$ ) coupled to a chiller (approximately $4^{\circ} \mathrm{C}$ ) where they were humidified and then concentrated using a virtual impactor. Immediately following, the particles were passed through a diffusion dryer, producing concentrated $\mathrm{PM}_{2.5}$ similar in dimension to the originally collected particles.

Charcoal- and HEPA-filtered room air was pumped through a second pump (GAST, Benton Harbor, MI) to further dry the particles, and a secondary exhaust pump facilitated the delivery of CAP to the stainless steel exposure chambers containing mice. HEPA-filtered air exposure was achieved in a similar fashion, without passing through the cyclone generator or the virtual impactor. Use of a DataRAM 4 (ThermoScientific) dual-wavelength nephelometric monitor allowed for real-time measurement of particle mass and median diameter; this ensured that the animals were being exposed to particulate matter only within the $\mathrm{PM}_{2.5}$ range.

Animals were euthanized at the end of the final six hour exposure period by sodium pentobarbital overdose. Blood was taken by cardiac puncture using EDTA as an 


\section{Figure 2}

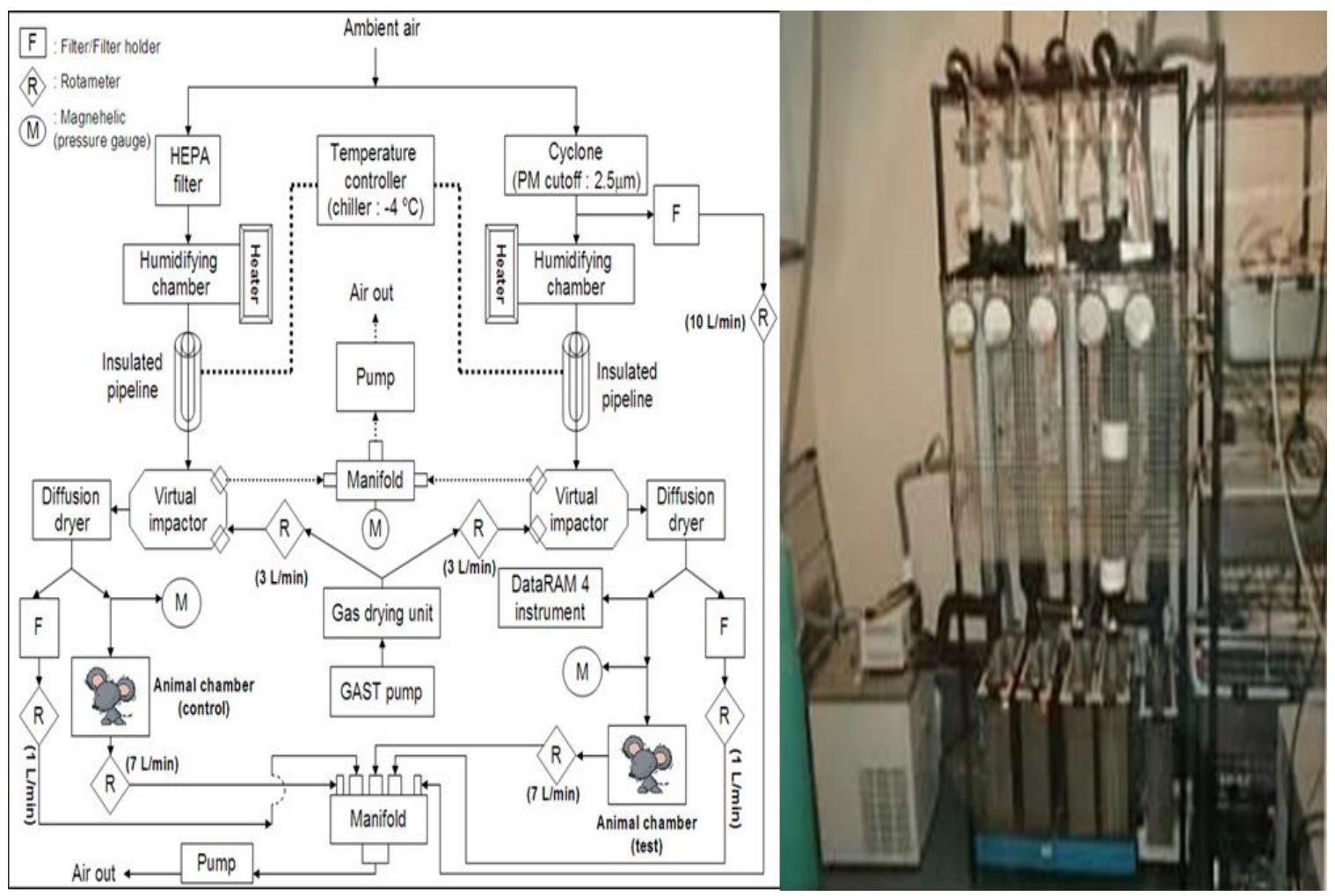

Figure 2: The versatile aerosol concentration enrichment system (VACES). The

VACES was used to concentrate ambient $\mathrm{PM}_{2.5}$ particles for in vivo murine exposure.

Ambient air was pulled into the system and used to separate and concentrate $\mathrm{PM}_{2.5}$, which was subsequently used in the exposure. High-efficiency particulate air (HEPA)filtered air was also used in the exposure to allow for an air control mouse population. 
anticoagulant and immediately centrifuged $\left(4.6 \mathrm{rpm}, 20 \mathrm{~min}, 4^{\circ} \mathrm{C}\right)$ to separate plasma. Additionally, heart, lungs, aorta, and perivascular adipose tissue (PVAT) were dissected, weighed, and immediately frozen in liquid nitrogen. All tissues were stored at $-80^{\circ} \mathrm{C}$ until time of analysis.

Total RNA was isolated from heart, lungs, aorta, and PVAT, $\mathrm{n}=5-8$ for each exposure group, using TRIzol (Invitrogen, Merelbeke, Belgium) and RNeasy MiniKit (Qiagen, Hilden, Germany) per manufacturer's instructions. The total RNA was eluted from miRNeasy minicolumns in $30 \mu \mathrm{L}$ of RNAse free water and the concentration determined using a NanoDrop 2000c spectrophotometer (ThermoScientific, Wilmington, DE). The resulting concentration was used in the synthesis of cDNA via iScript cDNA Synthesis Kit (Bio-Rad, Hercules, CA) per manufacturer's instructions. Briefly, $15 \mu \mathrm{L}$ of denatured RNA was mixed with $4 \mu \mathrm{L} 5 \mathrm{x}$ iScript reaction mix and $1 \mu \mathrm{L}$ iScript reverse transcriptase for a total volume of $20 \mu \mathrm{L}$. cDNA synthesis was performed in a MyCycler Thermal Cycler (Bio-Rad, Hercules, CA), and the total cDNA was either directly used for further analysis or stored at $-20^{\circ} \mathrm{C}$.

Total cDNA was diluted using RNAse free water immediately prior to use at a dilution of 1:5 for heart and lungs and 1:2.5 for PVAT. No dilution was used for aortic cDNA. Real-time quantitative PCR (qRT-PCR) was performed using iTaq universal SYBR Green supermix (Bio-Rad, Hercules, CA) per manufacturer's instructions. In short, $2 \mu \mathrm{L}$ diluted cDNA, $5.0 \mu \mathrm{L}$ iTaq $2 \mathrm{x}$ universal SYBR Green supermix, and $3 \mu \mathrm{L}$ of the primers of interest or of mouse ribosomal protein P0 (mRPPO), used as an internal control, were mixed and added to each well. Primers of interest consisted of mouse ET1, $\mathrm{ET}_{\mathrm{A}}$ receptor, and $\mathrm{ET}_{\mathrm{B}}$ receptor for all tissues as well as additional primers for markers 
of systemic perturbation in particular tissues, specifically osteopontin, calponin, and smooth muscle actin (SMA) in aorta and leptin in PVAT. qRT-PCR was run using protocols standard for Applied Biosystems 7900HT Fast Real-Time PCR System (Foster City, CA). Each sample was run in triplicate.

Sigma Plot 12.5 (San Jose, CA) and Microsoft Excel 2010 (Redmond, WA) were used for statistical analysis. The relative expression (RQ) of each sample was calculated using the threshold cycle (CT) value for each sample and the following equations:

$$
\begin{gathered}
\Delta C T=\text { Average of triplicate } C T_{\text {Target }}-\text { Average of triplicate } C T_{R P P O} \\
\Delta \triangle C T=\Delta C T_{C A P \text { Exposure Target }}-\Delta C T_{\text {Air Exposure Target }} \\
R Q=2^{-\Delta \Delta C T}
\end{gathered}
$$

RQ values were used to compare CAP exposure expression of the target compared to normalized air exposure expression. Rank sum tests were performed on the RQ values to find significant differences between groups based on duration and concentration of exposure or between murine models. Data expressed as mean \pm SD. Statistical significance assumed at $\mathrm{p}<0.05$. 


\section{RESULTS}

\section{HUMAN STUDY}

The human subject population for this study consisted of 8 males and 8 females between the ages of 18 and 26. A demographic summary of the study participants stratified by median ET-1 level is given in Table 2, with each collected blood sample being treated as an individual sample. Measured variables were grouped into common categories. There was no significant difference between the ET-1 groups and gender or age. All three environmental factors - temperature, relative humidity, and barometric pressure - were significantly different between the ET-1 groups, as were both stromal cell-derived factor -1 and red blood cell count. No differences in fibrinogen, plateletmonocyte aggregates, interleukin 6 , interleukin $1 \beta, \mathrm{VEGF}$, hsCRP, platelet factor 4, white blood cell count, cholesterol, high density lipoprotein, low density lipoprotein, triglycerides, albumin, or total plasma protein were observed (Table 2).

Analysis of the association between overall ET-1 levels and the blood parameters with adjustments for subject-specific fixed variables showed positive associations between ET-1 and platelet-monocyte aggregates, interleukin 6, albumin, and total plasma protein and a negative association with white blood cell count (Table 3). Comparison of ET-1 levels for each individual at the four blood draws with $\mathrm{PM}_{2.5}$ levels at each time point revealed an inverse association between the two factors (Figure 3). A similar outcome was seen when ET-1 levels were stratified, with the highest ET-1 levels found 


\section{Table 2}

\begin{tabular}{|c|c|c|c|c|}
\hline Demographic & \multicolumn{4}{|l|}{ Total } \\
\hline $\begin{array}{l}\text { Gender } \\
\text { Female } \\
\text { Male } \\
\text { Aqe (vears) }\end{array}$ & \multicolumn{4}{|l|}{$8(50 \%)$} \\
\hline Measurements: Variable - n (\%) or mean \pm SD & $\begin{array}{l}\text { Total } \\
\mathrm{n}=63\end{array}$ & $\begin{array}{l}\text { Low } \\
\mathrm{n}=31\end{array}$ & $\begin{array}{l}\text { High } \\
\mathrm{n}=32\end{array}$ & p-value \\
\hline \multicolumn{5}{|l|}{ Environmental Factors } \\
\hline Temperature $\left({ }^{\circ} \mathrm{F}\right)$ & $38 \pm 11$ & $31 \pm 7$ & $45 \pm 10$ & $<0.001^{*}$ \\
\hline Relative Humidity (\%) & $56 \pm 11$ & $61 \pm 8$ & $52 \pm 12$ & $0.002^{*}$ \\
\hline Barometric Pressure (inHg) & $30.0 \pm 0.3$ & $30.2 \pm 0.2$ & $30.0 \pm 0.3$ & $<0.001^{*}$ \\
\hline \multicolumn{5}{|l|}{ Blood Parameters } \\
\hline $\begin{array}{l}\text { Thrombosis } \\
\text { Fibrinogen }(\mathrm{mg} / \mathrm{dL}) \\
\text { Platelet-monocyte aggregates }\end{array}$ & $\begin{aligned} 599 & \pm 979 \\
6 & \pm 3\end{aligned}$ & $\begin{aligned} 436 & \pm 175 \\
5 & \pm 3\end{aligned}$ & $\begin{array}{l}757 \pm 1354 \\
\quad 6 \pm 3\end{array}$ & $\begin{array}{l}0.195 \\
0.195\end{array}$ \\
\hline Serum Amyloid A $(\mu \mathrm{g} / \mathrm{mL})$ & $153 \pm 303$ & $158 \pm 305$ & $149 \pm 306$ & 0.439 \\
\hline Interleukin 6 (pg/mL) & $0.92 \pm 0.9$ & $0.61 \pm 0.5$ & $1.23 \pm 1.1$ & 0.106 \\
\hline Interleukin $1 \beta(\mathrm{pg} / \mathrm{mL})$ & $5 \pm 2$ & $5 \pm 1$ & $5 \pm 2$ & 0.694 \\
\hline VascularEndothelial Growth Factor $(\mathrm{pg} / \mathrm{mL})$ & $113 \pm 26$ & $114 \pm 28$ & $112 \pm 25$ & 0.799 \\
\hline Stromal Cell-Derived Factor-1 $(\mathrm{pg} / \mathrm{mL})$ & $2643 \pm 382$ & $2745 \pm 396$ & $2545 \pm 346$ & $0.045^{*}$ \\
\hline $\begin{array}{l}\text { Inflammation } \\
\text { hsCRP (mg/L) }\end{array}$ & $0.12 \pm 0.2$ & $0.09 \pm 0.1$ & $0.15 \pm 0.2$ & 0.388 \\
\hline Platelet Factor $4(\mathrm{pg} / \mathrm{mL})$ & $1032 \pm 403$ & $1045 \pm 239$ & $1014 \pm 569$ & 0.335 \\
\hline White Blood Cells $(M / \mu L)$ & $7 \pm 2$ & $7 \pm 2$ & $6 \pm 2$ & 0.066 \\
\hline 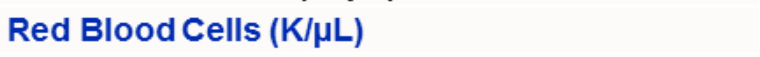 & $4.8 \pm 0.5$ & $5.0 \pm 0.5$ & $4.7 \pm 0.5$ & $0.050^{*}$ \\
\hline $\begin{array}{l}\text { Lipids } \\
\text { Cholesterol (mg/dL) } \\
\text { High Density Lipoprotein (mg/dL) } \\
\text { Low Density Lipoprotein (mg/dL) }\end{array}$ & $\begin{array}{c}163 \pm 33 \\
52 \pm 9 \\
82 \pm 23\end{array}$ & $\begin{array}{c}161 \pm 35 \\
52 \pm 9 \\
80 \pm 25\end{array}$ & $\begin{array}{c}164 \pm 31 \\
52 \pm 9 \\
84 \pm 23\end{array}$ & $\begin{array}{l}0.606 \\
0.922 \\
0.529\end{array}$ \\
\hline Triglycerides (mg/dL) & $74 \pm 38$ & $80 \pm 47$ & $67 \pm 27$ & 0.173 \\
\hline Albumin (g/dL) & $4.9 \pm 0.5$ & $4.7 \pm 0.5$ & $5.0 \pm 0.5$ & 0.084 \\
\hline Total Plasma Protein (g/dL) & $7.5 \pm 0.9$ & $7.3 \pm 1.0$ & $7.6 \pm 0.8$ & 0.113 \\
\hline
\end{tabular}

Table 2: Demographic summary of the study participants stratified by median ET-1.

Low ET-1 $\leq 0.6881 \mathrm{pg} / \mathrm{mL}$, high ET-1 $>0.6881 \mathrm{pg} / \mathrm{mL}$. Platelet-monocyte aggregates are given as the $\%$ total of cells $\mathrm{CD} 41^{+} / 45^{+}$. For vascular endothelial growth factor and platelet factor $4, \mathrm{n}=32$. * indicates significance at the $\mathrm{p}<0.05$ level. 


\section{Table 3}

\begin{tabular}{|l|c|c|c|c|}
\hline Variable & Cardiovascular Indicator & $\boldsymbol{\beta}$ & $\mathbf{p}$-value & $\begin{array}{r}\mathbf{9 5 \%} \text { Confidence } \\
\text { Interval }\end{array}$ \\
\hline Platelet-monocyte Aggregates & Thrombosis & 0.254 & $0.026^{*}$ & $0.033-0.475$ \\
\hline Interleukin 6 & Inflammation & 1.255 & $0.039^{*}$ & $0.063-2.447$ \\
\hline White Blood Cells & Inflammation & -0.359 & $0.040^{*}$ & $-0.701--0.016$ \\
\hline Albumin & Blood Pressure & 1.627 & $0.008^{*}$ & $0.425-2.830$ \\
\hline Total Plasma Protein & $\begin{array}{c}\text { Blood Pressure } \\
\text { Thrombosis }\end{array}$ & 1.153 & $0.004^{*}$ & $0.360-1.946$ \\
\hline
\end{tabular}

Table 3: Association between ET-1 levels and blood study variables. Generalized linear models were used to compare ET-1 and plasma components of interest. Models were adjusted for gender, age, and $\mathrm{PM}_{2.5}$ (average of 24 hours before blood draw). Plateletmonocyte aggregates, interleukin 6 , albumin, and total plasma proteins were all positively correlated with high ET-1. * indicates significance at the $\mathrm{p}<0.05$ level. 


\section{Figure 3}

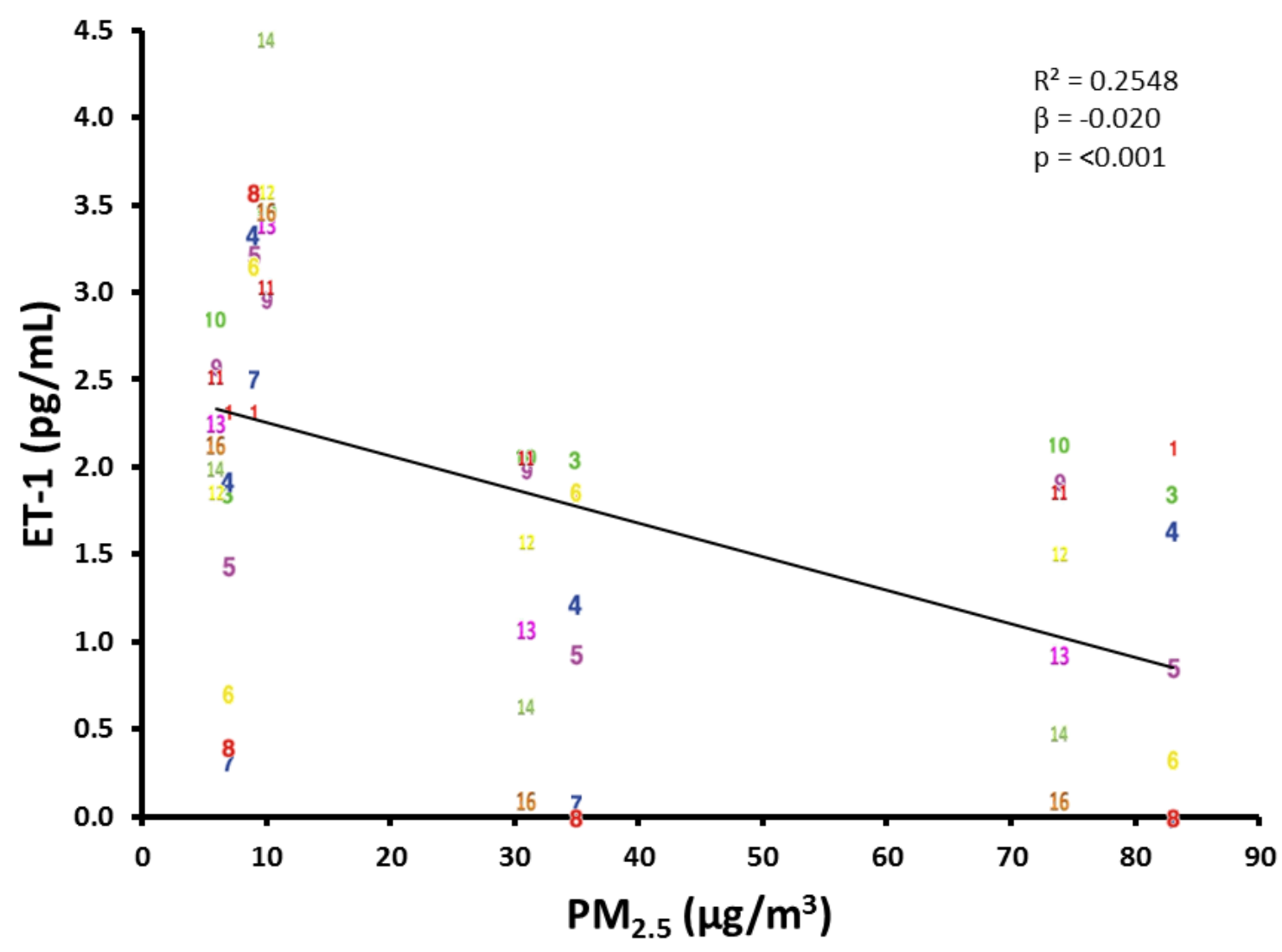

Figure 3: Inverse association between PM2.5 and ET-1. Previous 24 hour $\mathrm{PM}_{2.5}$ levels were regressed against ET-1 using a generalized linear model. Colored numbers represent study subjects at each individual blood draw. Data indicate a significant inverse association between the two factors, with the highest ET-1 levels measured in blood samples collected at the lowest $\mathrm{PM}_{2.5}$ exposures. 
after the lowest $\mathrm{PM}_{2.5}$ exposures (Figure $4 \mathrm{~A}$ ). $\mathrm{PM}_{2.5}$ was also compared to plasma components with a significant association with ET-1 (Figure 4B-F). ET-1 levels were additionally compared to previously measured levels for six unique EPC populations (Table 4). The majority of these populations showed no association, as represented by the most abundant EPC population in Figure 5, but a strongly positive association was seen between ET-1 and EPC-4 (CD31 $\left.1 / 34^{+} / 45^{+} / \mathrm{ACC} 133^{+}\right)$(Figure 6).

\section{ANIMAL STUDIES}

A summary of the murine exposures is given in Table 5. The concentration of each exposure was calculated and used to classify each exposure as low or medium (Table 5). The exposures in December 2014 and April 2015 had similar concentrations (21 $\mu \mathrm{g} / \mathrm{m}^{3}$ and $18 \mu \mathrm{g} / \mathrm{m}^{3}$, respectively) and were combined to increase sample size. The body weight of each mouse was measured before and after exposure; mice had normal body weights and did not show any visible signs of distress in response to exposure (Figure 7). Comparisons of the calculated RQ values between the air and CAP exposed mice for each exposure were made to examine the effect of exposure on the gene expression of the ET-1 system and of other systemic markers. An acute, low $\mathrm{PM}_{2.5}$ exposure showed no effect in the tissues in C57BL/6 mice (Figure 8A-D). A higher concentration exposure of the same duration, however, resulted in significant changes in expression of the ET-1 receptors in the heart (Figure 9A-D). In ecSOD-Tg mice, the same acute, low $\mathrm{PM}_{2.5}$ exposure had no significant effect in the heart (Figure 10A) or the PVAT (Figure 10D), but led to strongly significant increases in the gene expression of the clearance receptor in the lungs (Figure 10B) and in smooth muscle actin in the aorta 


\section{Figure 4}
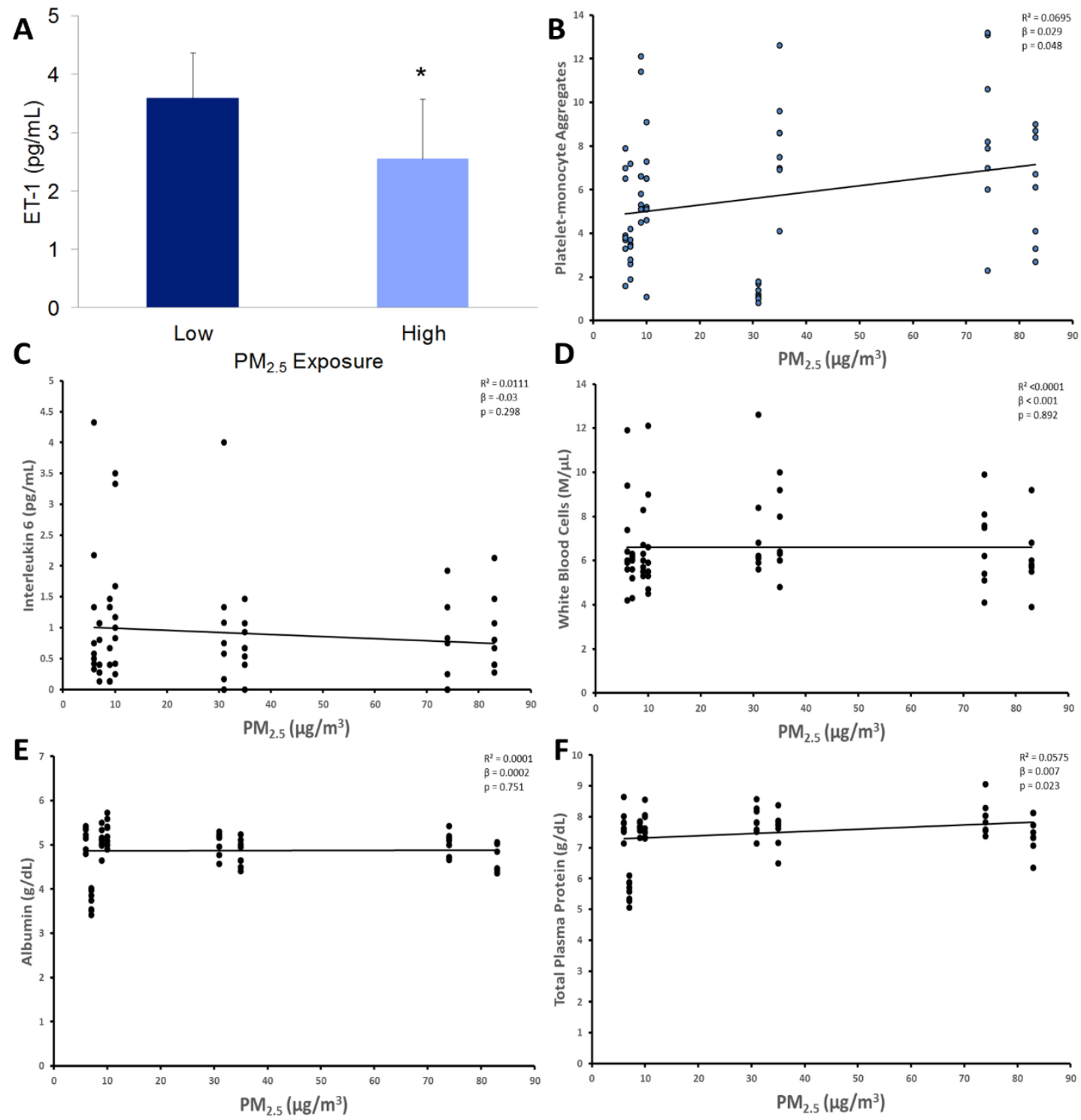

Figure 4: Association between PM2.5 and blood variables. Associations between $\mathrm{PM}_{2.5}$ and ET-1 (A), platelet-monocyte aggregates (B), interleukin 6 (C), white blood cells (D), albumin $(\mathrm{E})$, and total plasma protein $(\mathrm{F}) . \quad$ Mean \pm SEM ET-1 levels for low $\left(\mathrm{PM}_{2.5}<15\right.$ $\left.\mu \mathrm{g} / \mathrm{m}^{3}\right)$ and high $\left(\mathrm{PM}_{2.5}>15 \mu \mathrm{g} / \mathrm{m}^{3}\right)$. Stratified ET-1 levels indicate a significant inverse association with $\mathrm{PM}_{2.5}$, with various associations between $\mathrm{PM}_{2.5}$ and the other variables, indicating varying downstream outcomes. * indicates significance at $\mathrm{p}<0.05$. 


\begin{tabular}{llll}
\hline EPC Population & $\mathbf{R}^{2}$ & $\boldsymbol{\beta}$ & $\mathbf{p}$-value \\
\hline Cell type-1 & 0.018 & 0.471 & 0.299 \\
Cell type-2 & 0.052 & 0.870 & 0.072 \\
Cell type-3 & 0.005 & 0.159 & 0.597 \\
Cell type-4 & 0.074 & 0.826 & $0.034^{*}$ \\
Cell type-5 & 0.010 & -0.179 & 0.440 \\
Cell type-6 & 0.034 & 0.640 & 0.149 \\
\hline
\end{tabular}

Table 4: Association between ET-1 and EPC levels. Estimation regression was used to compare ET-1 and circulating EPC levels for six cell populations. * indicates significance at the $\mathrm{p}<0.05$ level. 


\section{Figure 5}

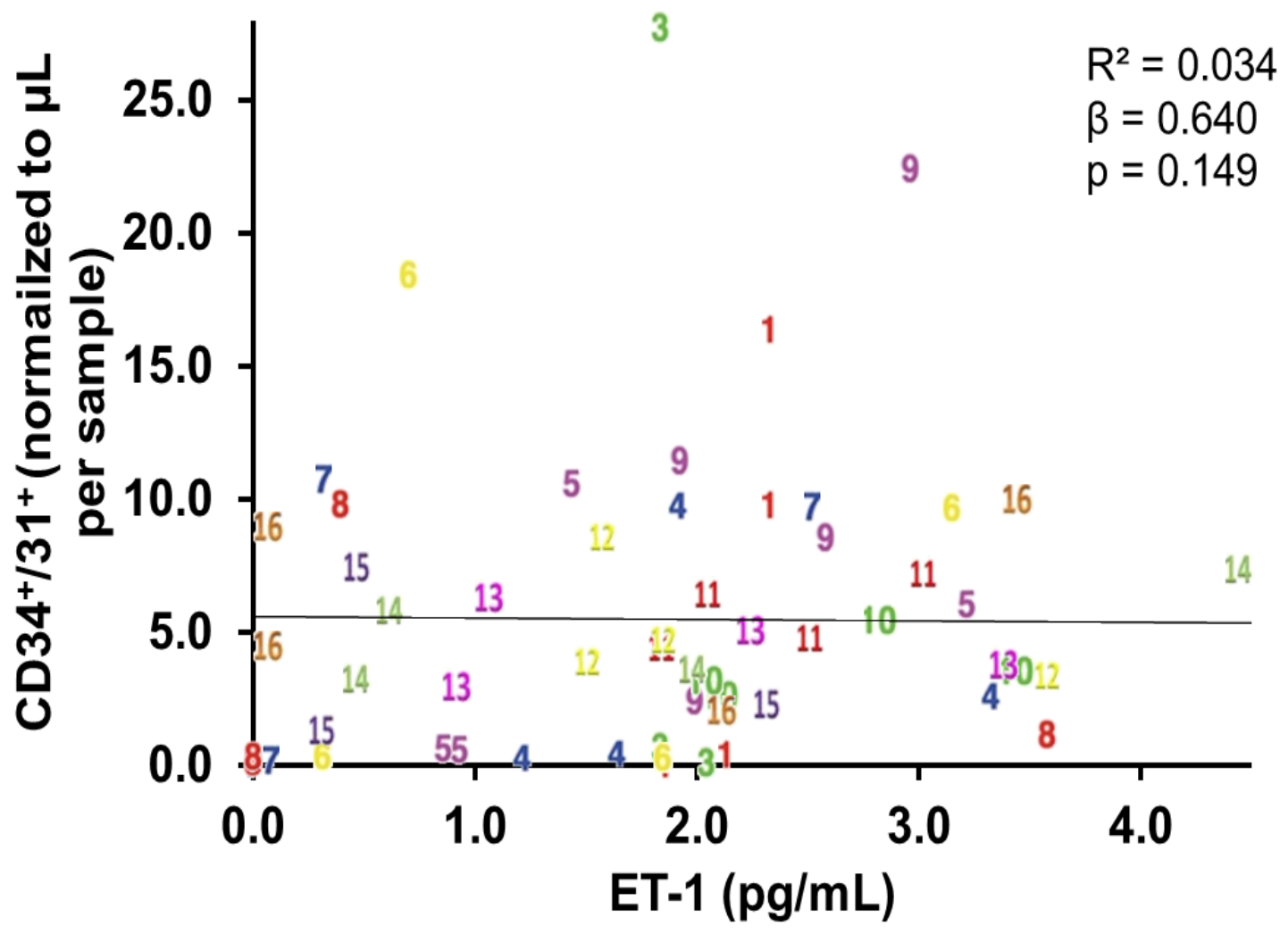

Figure 5: No association between ET-1 and CD34+/31+ cells. ET-1 levels measured in each blood draw for each individual were regressed against levels of EPC-6, the most abundant cell population measured in the study subjects, in each blood draw for each individual. Regression indicates that there is no association between overall ET-1 and CD $34^{+} / 31^{+}$cells. 


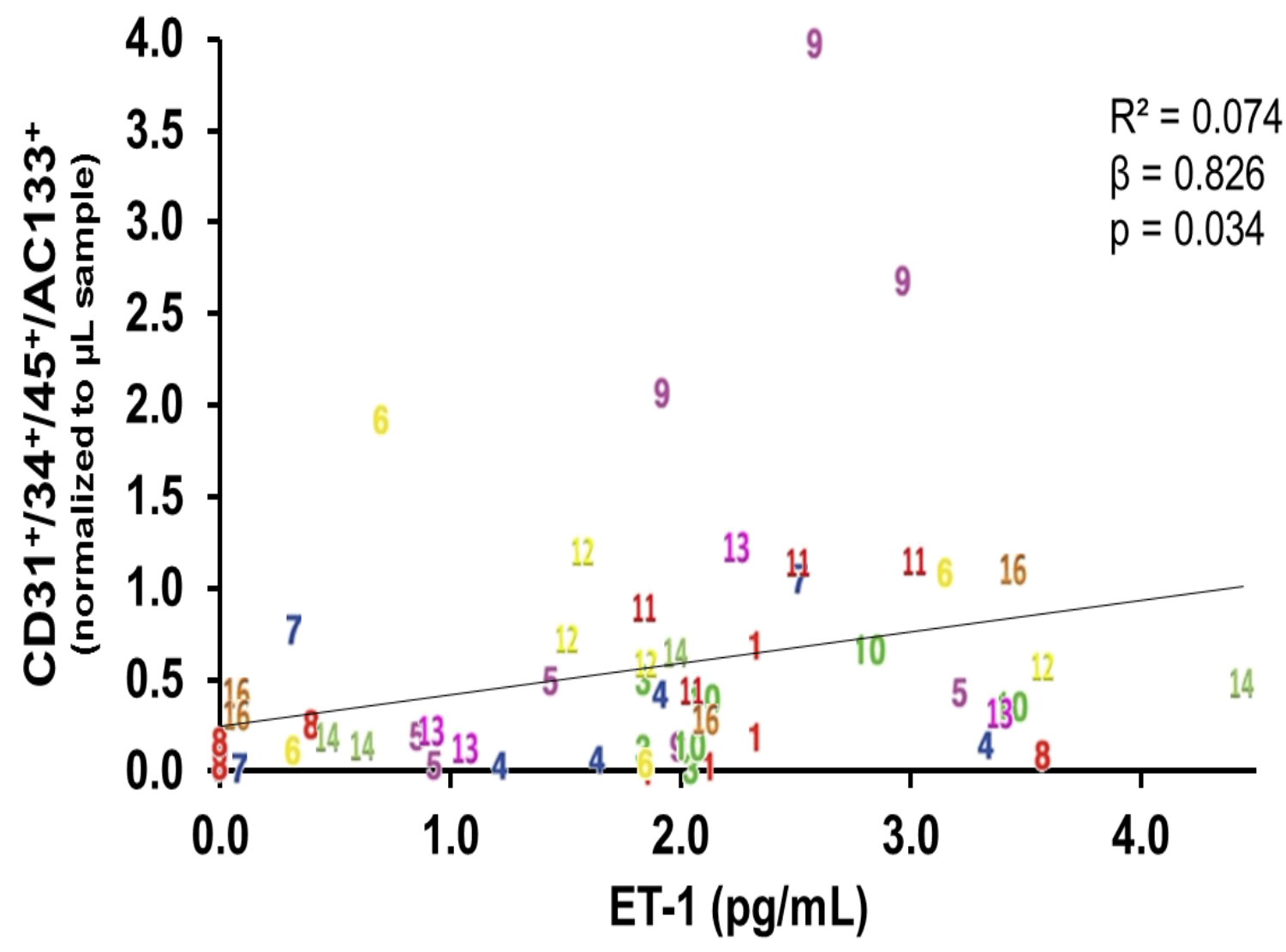

Figure 6: Positive association between ET-1 and CD31 ${ }^{+} / 34^{+} / 45^{+} / \mathrm{ACC} 133^{+}$cells. ET-1 levels measured in each blood draw for each individual were regressed against levels of EPC-4 in each blood draw for each individual. Regression indicates a significantly positive association between overall ET- 1 and $\mathrm{CD} 31^{+} / 34^{+} / 45^{+} / \mathrm{ACC} 133^{+}$cells. 


\section{Table 5}

\begin{tabular}{|c|c|c|c|c|}
\hline Exposure Dates & Duration & $\begin{array}{c}\mathrm{PM}_{2.5} \text { Concentration } \\
\left(\mu \mathrm{g} / \mathrm{m}^{3}\right)\end{array}$ & Murine Model(s) & Sample Size \\
\hline December 2014 & 9 days & 21 (Low) & $\begin{array}{l}\text { C57BL/6 } \\
\text { ecSOD-Tg }\end{array}$ & $\begin{array}{l}\text { Air }=5, \mathrm{CAP}=5 \\
\text { Air }=6, \mathrm{CAP}=6\end{array}$ \\
\hline January 2015 & 9 days & 56 (Medium) & C57BL/6 & Air $=8, C A P=8$ \\
\hline February 2015 & 30 days & 49 (Medium) & $\begin{array}{l}\text { C57BL/6 } \\
\text { ecSOD-Tg }\end{array}$ & $\begin{array}{l}\text { Air }=6, C A P=5 \\
\text { Air }=6, C A P=6\end{array}$ \\
\hline April 2015 & 9 days & 18 (Low) & C57BL/6 & Air $=5, C A P=5$ \\
\hline
\end{tabular}

Table 5: Summary of murine exposures. Each exposure lasted six hours per day for the duration noted. 


\section{Figure 7}

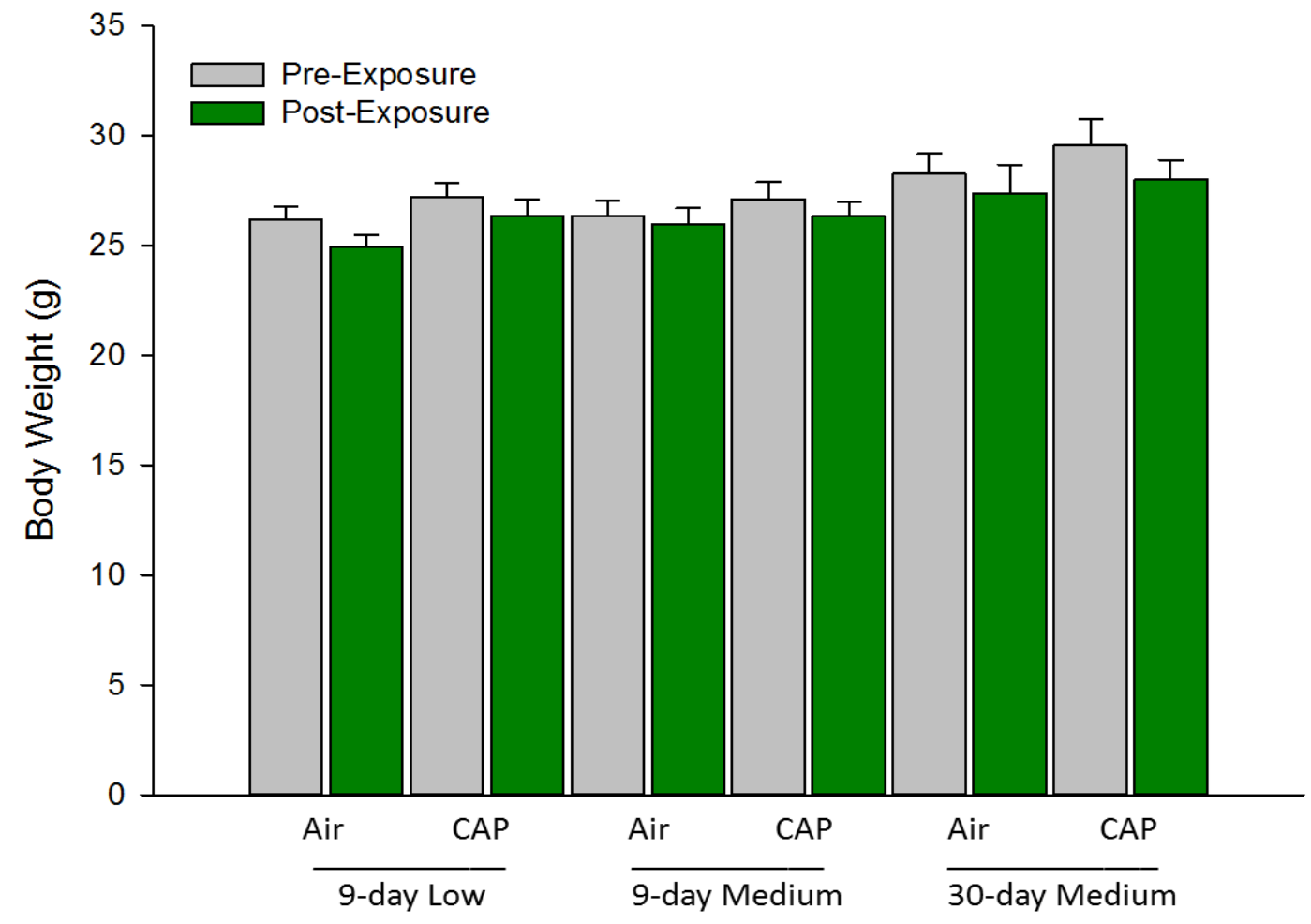

Figure 7: Body weight of C57BL/6 mice before and after exposures. Mean \pm SE body weights for C57BL/6 mice exposed to CAP at varying concentrations and durations. Comparison of the body weights before and after exposure showed no significant difference, with all mice showing normal body weights at each time point. 


\section{Figure 8}
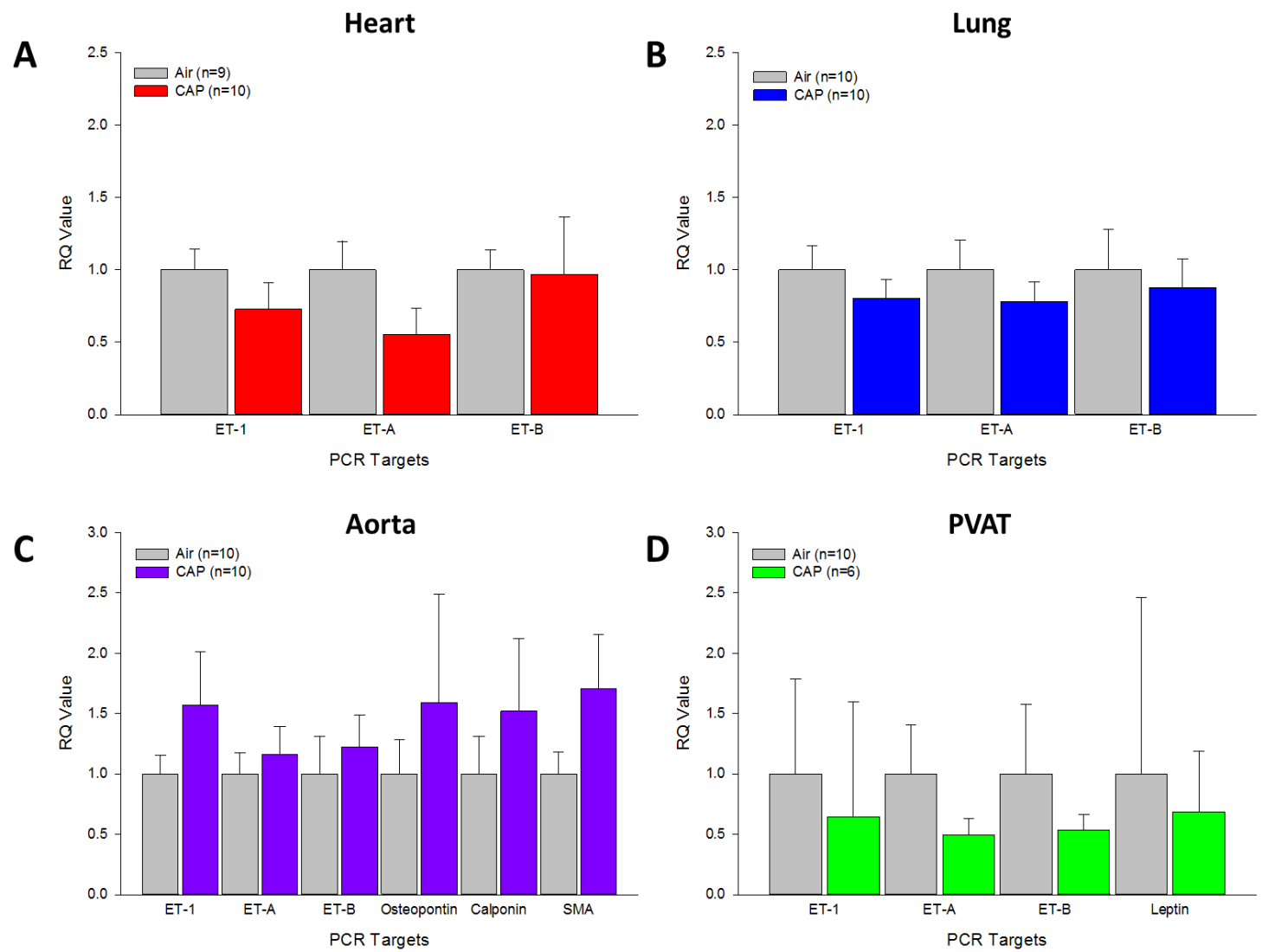

Figure 8: mRNA expression of C57BL/6 cardiopulmonary tissues after an acute, low

concentration CAP exposure. Mean + SD gene expression of the ET-1 system and other markers of interest in heart (A), lung (B), aorta (C), and PVAT (D) tissue after nine days of CAP exposure. Acute exposure to low concentration CAP did not cause any significant changes in the tissues of C57BL/6 mice. 


\section{Figure 9}

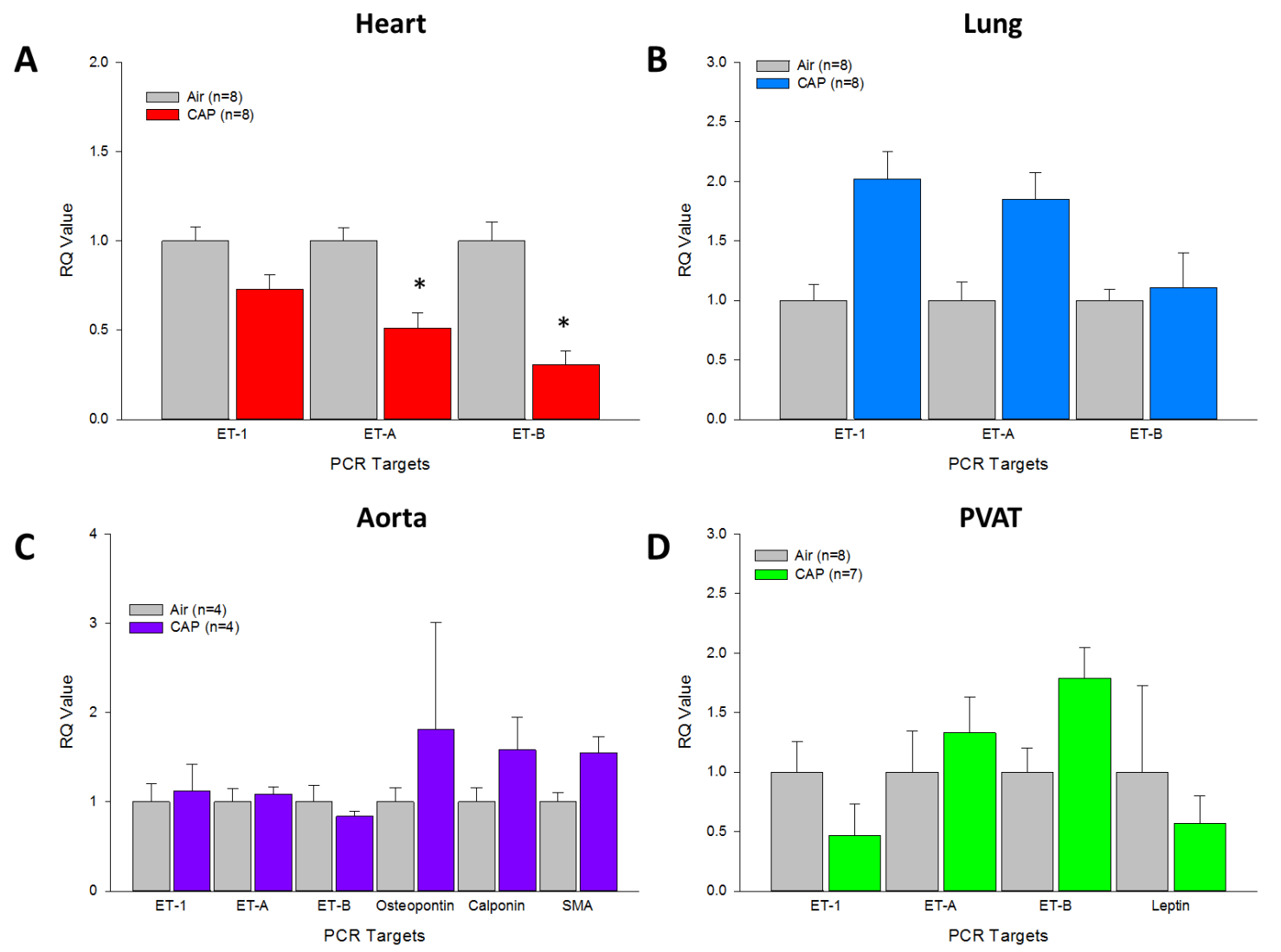

Figure 9: $m R N A$ expression of C57BL/6 cardiopulmonary tissues after an acute, medium concentration CAP exposure. Mean + SD gene expression of the ET-1 system and other markers of interest in heart (A), lung (B), aorta (C), and PVAT (D) tissue after nine days of CAP exposure. Acute exposure to medium concentration CAP significantly decreased gene expression of the ET-1 receptors in the heart of C57BL/6 mice. * indicates significance at $\mathrm{p}<0.05$. 


\section{Figure 10}

A

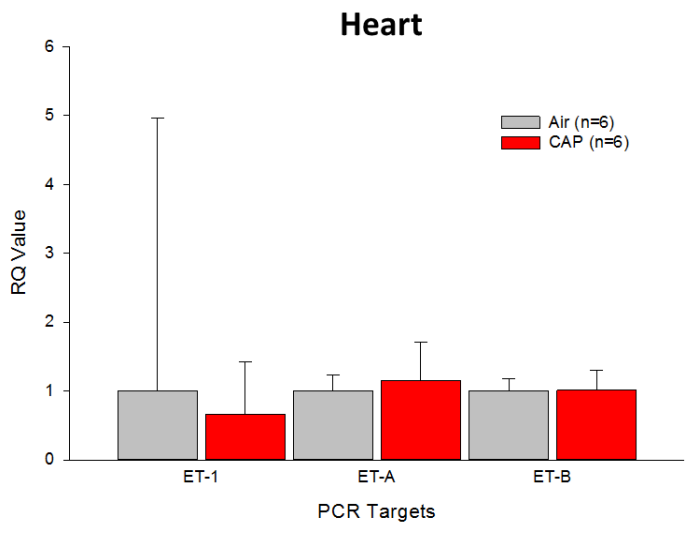

C

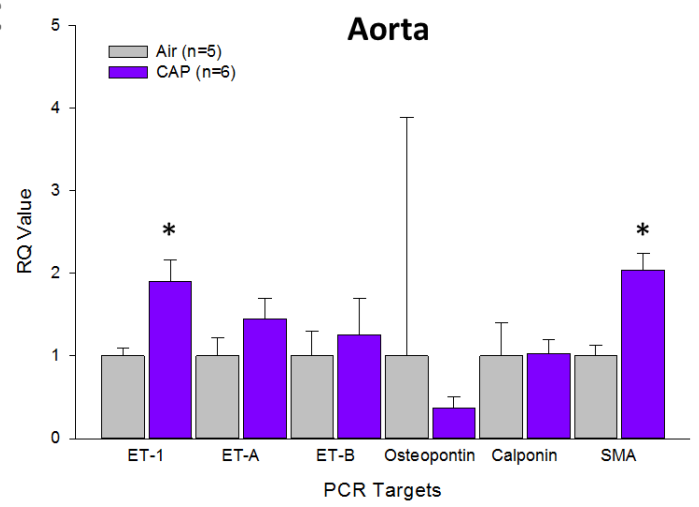

B

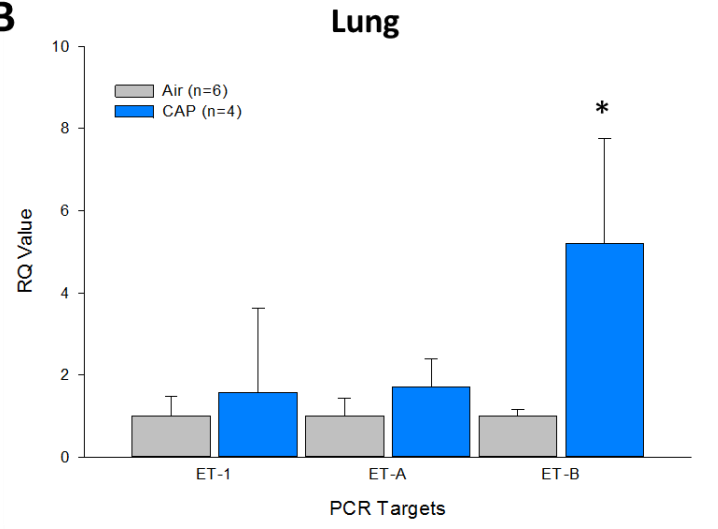

D

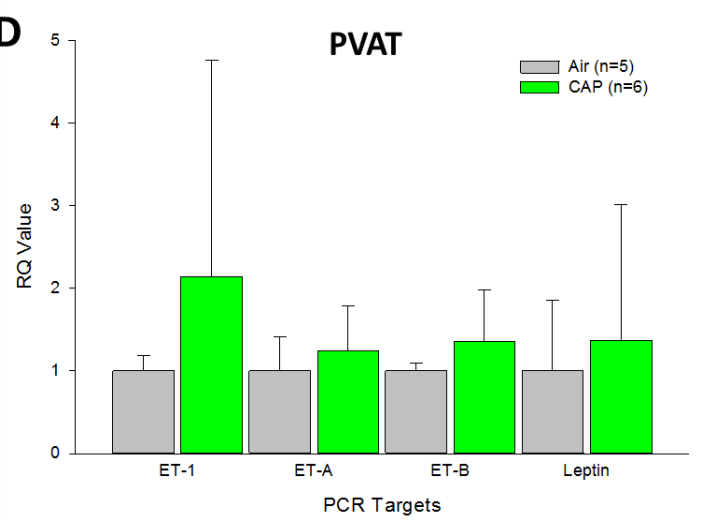

Figure 10: mRNA expression of ecSOD-Tg cardiopulmonary tissues after an acute, low concentration CAP exposure. Mean + SD gene expression of the ET-1 system and other markers of interest in heart (A), lung (B), aorta (C), and PVAT (D) tissue after nine days of CAP exposure. Acute exposure to low concentration CAP significantly increased gene expression of the ET-B receptor in the lungs and within ET-1 and smooth muscle actin in the aorta of ecSOD-Tg mice. * indicates significance at $\mathrm{p}<0.05$. 
(Figure 10C). Chronic exposure to C57BL/6 mice at a middling $\mathrm{PM}_{2.5}$ concentration caused strongly significant changes in the gene expression of the receptors in both the heart (Figure 11A) and lungs (Figure 11B) and in smooth muscle actin in the aorta (Figure 11C). Although expression of both ET-1 and leptin genes was increased in PVAT, these increases were not significant (Figure 11D). Conversely, gene expression of the receptors in both the heart and lungs in the ecSOD-Tg mice in this exposure were not significantly changed, although there was a trend towards an decrease in the $\mathrm{ET}_{\mathrm{B}}$ receptor in the heart (Figure 12A) and in the lungs (Figure 12B). There was also a strong but nonsignificant decrease in smooth muscle actin gene expression in the aorta (Figure 12C) and a similarly strong but nonsignificant increase in ET-1 gene expression in the PVAT (Figure 12D).

Comparisons were also made between the exposures of varying concentrations and durations to examine the specific effects of these characteristics on gene expression in the cardiopulmonary system. Looking at acute low versus medium exposures in C57BL/6 mice, the higher concentration exposure more significantly increased both ET-1 and the $\mathrm{ET}_{\mathrm{A}}$ receptor gene expression in the lungs (Figure 13B) compared to the lower exposure. There was also a greater increase in gene expression in both receptor types in the PVAT with higher $\mathrm{PM}_{2.5}$ (Figure 13D). Neither the heart (Figure 13A) nor the aorta (Figure 13C) were more affected by the higher concentration.

A comparison of the gene expressions between the C57BL/6 and ecSOD-Tg mice from the same acute, low $\mathrm{PM}_{2.5}$ exposure revealed differences only in the lungs (Figure 14B) and the aorta (Figure 14C), with significant changes in $\mathrm{ET}_{\mathrm{B}}$ in both tissues and in 


\section{Figure 11}

A

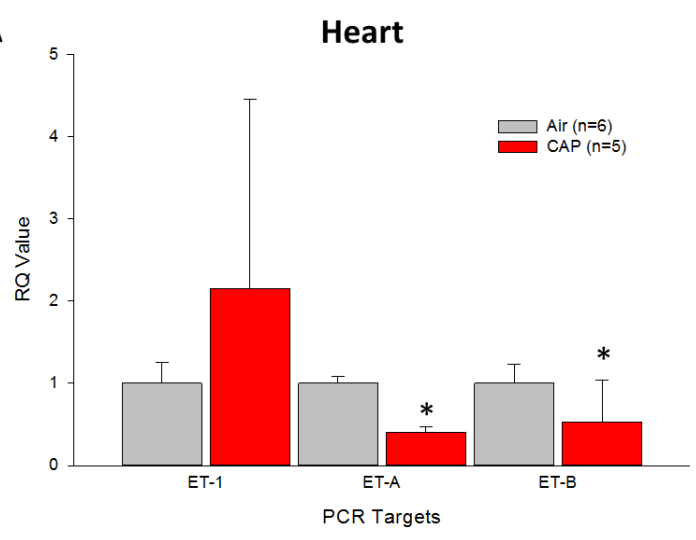

C

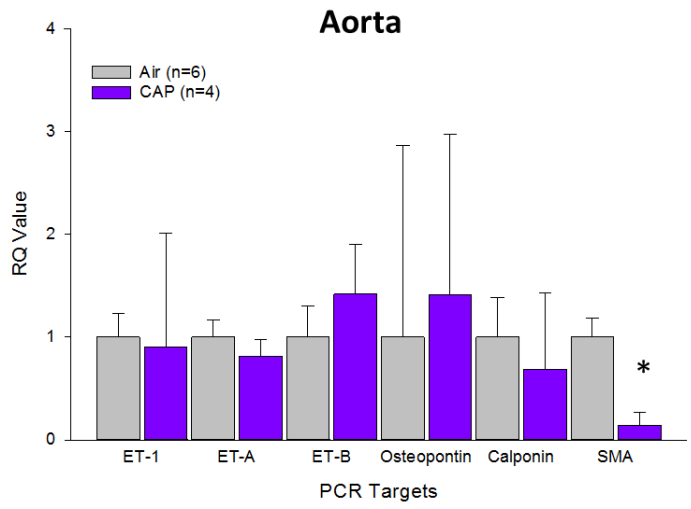

B

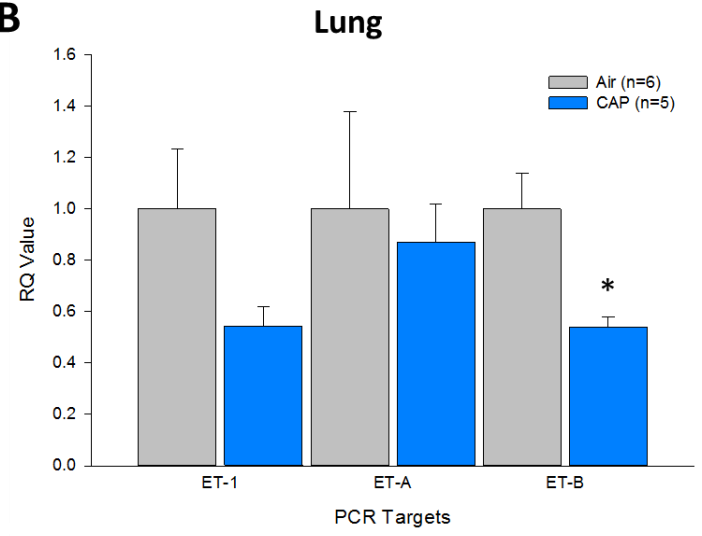

D

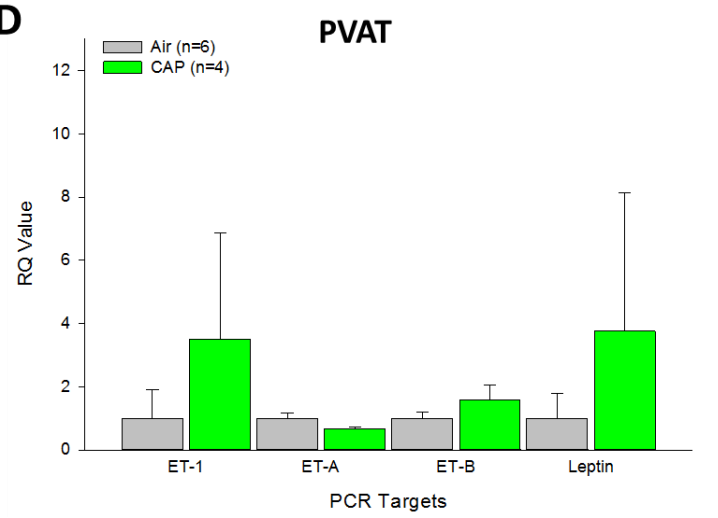

Figure 11: mRNA expression of C57BL/6 cardiopulmonary tissues after a chronic, medium concentration CAP exposure. Mean + SD gene expression of the ET-1 system and other markers of interest in heart (A), lung (B), aorta (C), and PVAT (D) tissue after 30 days of CAP exposure. Chronic exposure to medium concentration CAP significantly reduced gene expression within the ET-1 system of the heart and lungs and within markers of systemic disturbance in the aorta of C57BL/6 mice. * indicates significance at $\mathrm{p}<0.05$. 


\section{Figure 12}

A

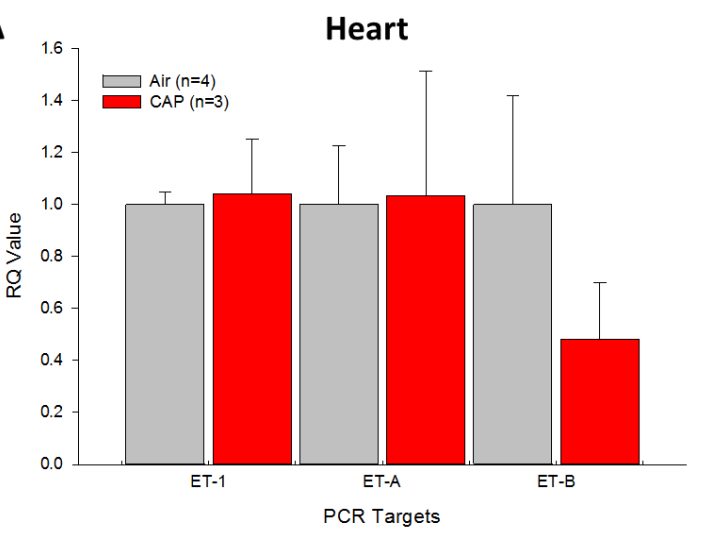

C

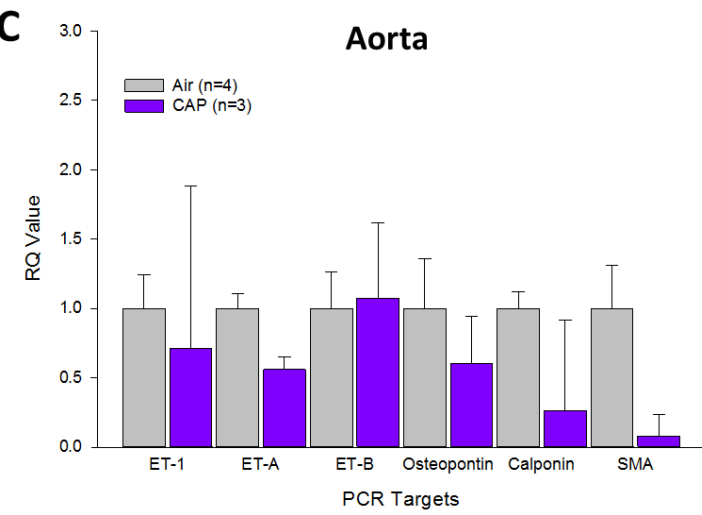

B Lung

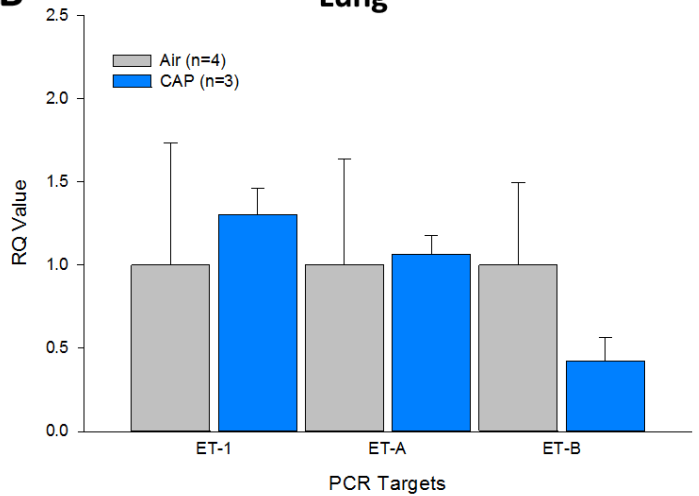

D $\left.{ }^{10}\right]$ Air (n=4) PVAT

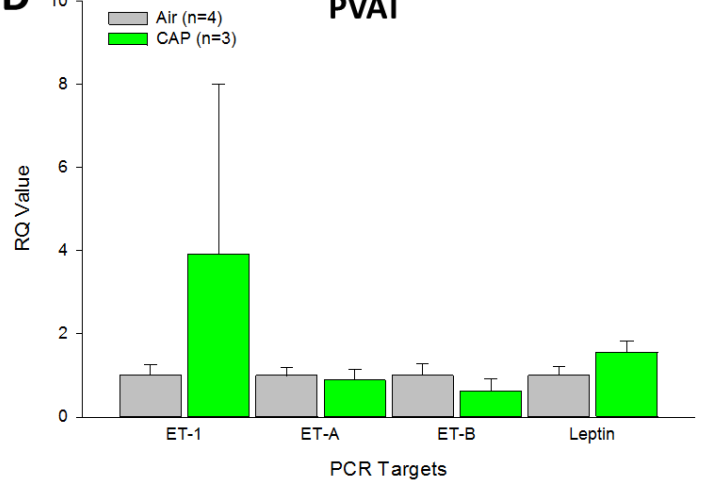

Figure 12: mRNA expression of ecSOD-Tg cardiopulmonary tissues after a chronic, medium concentration CAP exposure. Mean + SD gene expression of the ET-1 system and other markers of interest in heart (A), lung (B), aorta (C), and PVAT (D) tissue after 30 days of CAP exposure. Chronic exposure to medium concentration CAP did not cause any significant changes in the tissues of ecSOD-Tg mice. 


\section{Figure 13}
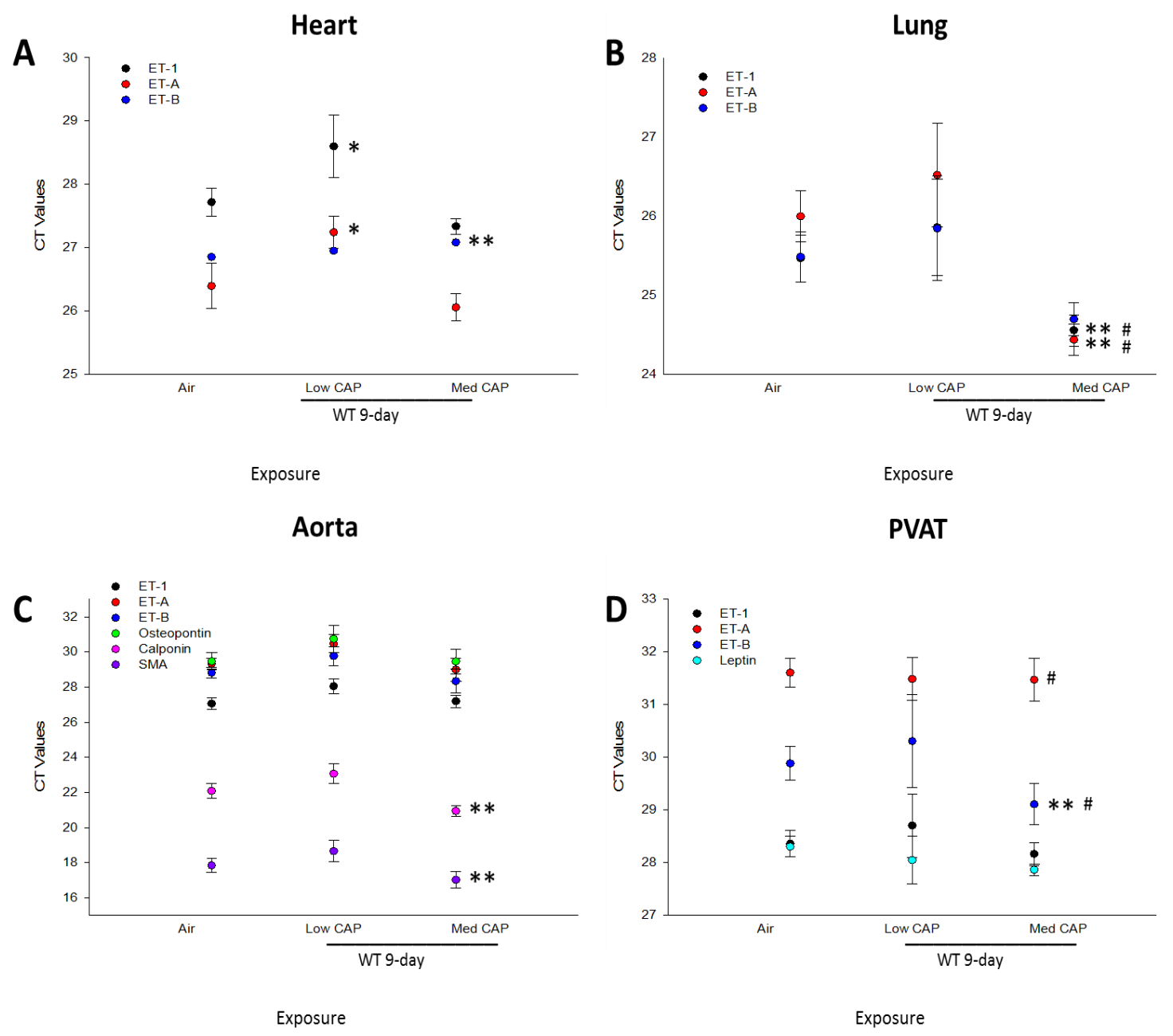

Figure 13: Comparison of mRNA expression of C57BL/6 cardiopulmonary tissues after acute low and medium concentration CAP exposures. Comparison of mean \pm SD gene expression of the ET-1 system and other markers of interest in heart (A), lung (B), aorta (C), and PVAT (D) tissue after nine days of varying CAP exposure. Medium concentration CAP exposure significantly increased gene expression of the ET-1 system in the lungs and PVAT in comparison to a low concentration CAP exposure in acutely exposed C57BL/6 mice. * indicates $\mathrm{p}<0.05$ compared to air. $* *$ indicates $\mathrm{p}<0.05$ compared to air. \# indicates $\mathrm{p}<0.05$ compared between CAP exposures. 


\section{Figure 14}
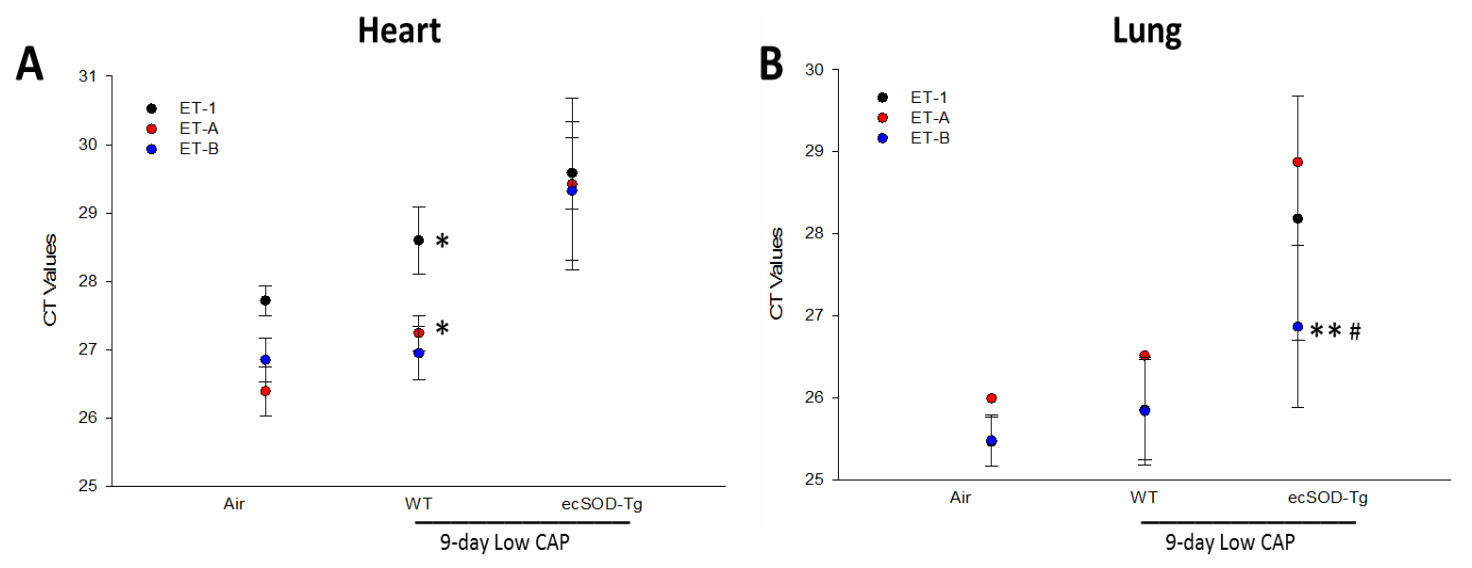

Exposure

Exposure

Aorta

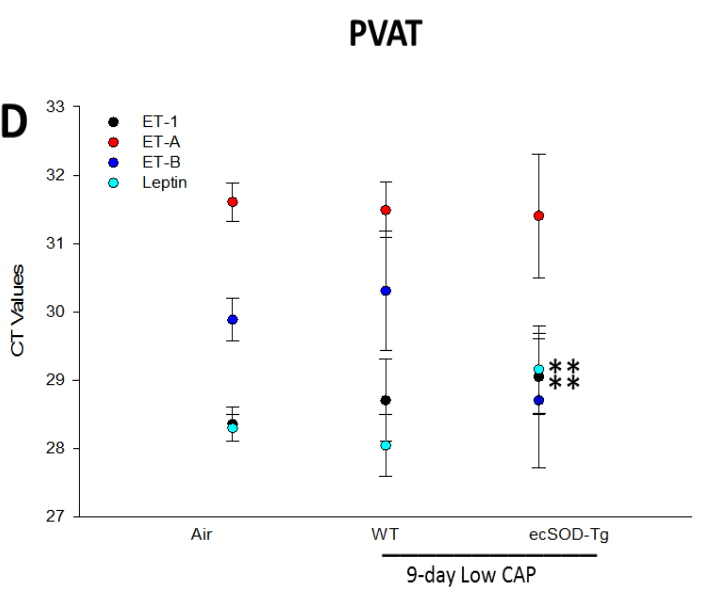

Exposure

Exposure

Figure 14: Comparison of $\mathrm{mRNA}$ expression of C57BL/6 and ecSOD-Tg

cardiopulmonary tissues after an acute, low concentration CAP exposure. Comparison of mean \pm SD gene expression of the ET-1 system and other markers of interest in heart (A), lung (B), aorta (C), and PVAT (D) tissue after nine days of CAP exposure. An ecSOD-Tg background significantly altered gene expression of the ET-1 system in the lungs and aorta in comparison to C57BL/6 mice in the same acute low concentration CAP exposure. * indicates $\mathrm{p}<0.05$ compared to air. $* *$ indicates $\mathrm{p}<0.05$ compared to air. \# indicates $\mathrm{p}<0.05$ compared between CAP exposures. 
also in ET-1 in the aorta. The heart (Figure 14A) and PVAT (Figure 14D) showed no significant difference between the two exposures. Duration of exposure had a significant impact in all the tissues at a similar medium $\mathrm{PM}_{2.5}$ concentration. After 30 days of exposure, $\mathrm{C} 57 \mathrm{BL} / 6$ mice had significant changes in the gene expression of $\mathrm{ET}_{\mathrm{A}}$ in the heart (Figure 15A), of both receptors in the PVAT (Figure 15D), of all ET-1 system genes in the lungs (Figure 15B), and of smooth muscle actin in the aorta (Figure 15C) compared to the levels after a 9-day exposure. Gene expression in these tissues were all more significantly decreased with the chronic exposure compared to the acute exposure.

Compared to C57BL/6 mice, ecSOD-Tg mice showed significantly increased gene expression of pulmonary ET- 1 and the $\mathrm{ET}_{\mathrm{A}}$ receptor after the same chronic, medium $\mathrm{PM}_{2.5}$ exposure (Figure 16B). No differences were seen between the two mouse models in the heart (Figure 16A), aorta (Figure 16C), or the PVAT (Figure 16D). 


\section{Figure 15}
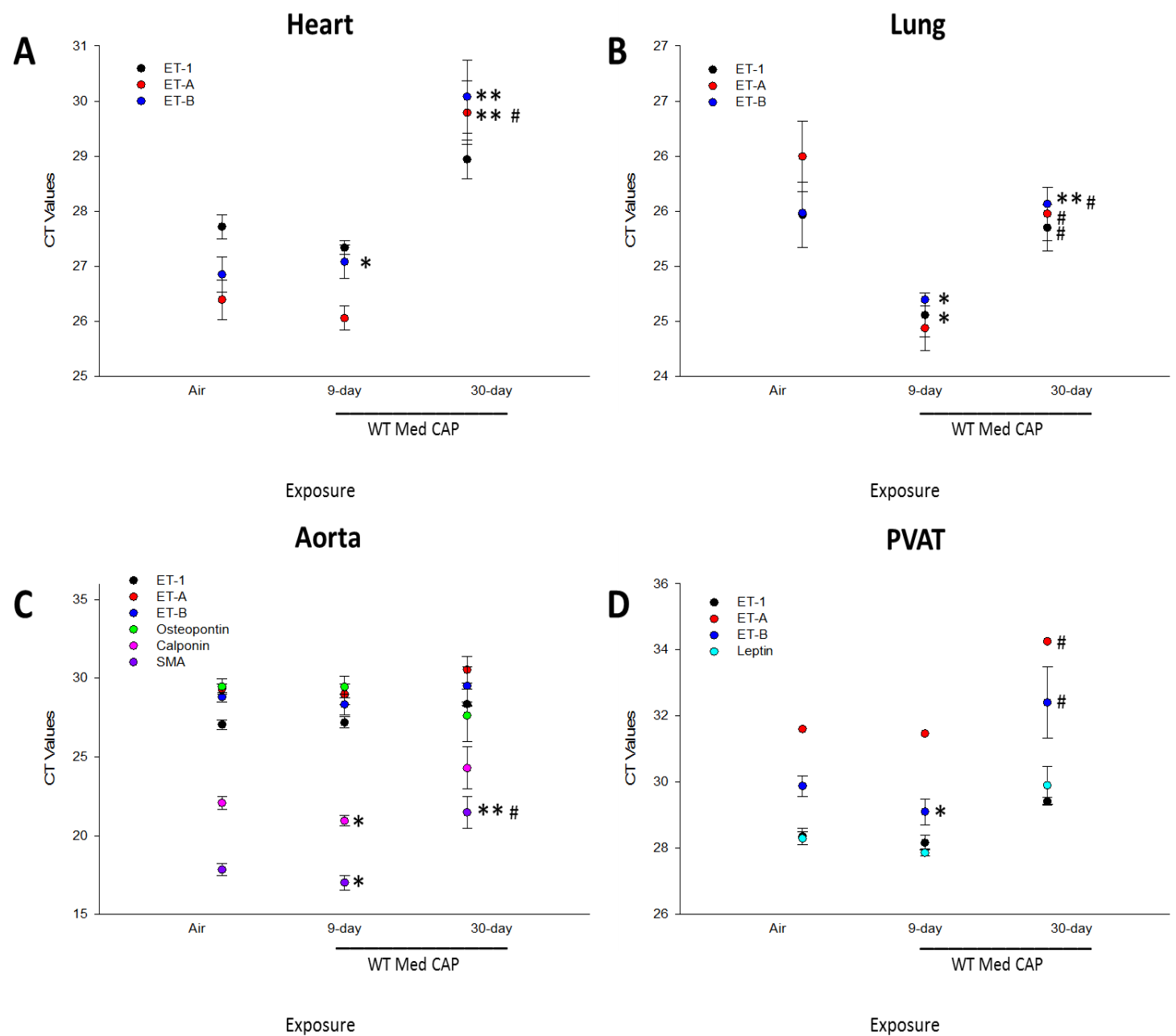

Figure 15: Comparison of $m R N A$ expression of C57BL/6 cardiopulmonary tissues after acute and chronic medium concentration CAP exposures. Comparison of mean \pm SD gene expression of the ET-1 system and other markers of interest in heart (A), lung (B), aorta (C), and PVAT (D) tissue after varying durations of medium CAP exposure. Chronic exposure significantly decreased gene expression of the ET-1 system and other markers in all tissues of C57BL/6 mice compared to an acute exposure of a similar medium CAP concentration. * indicates $\mathrm{p}<0.05$ compared to air. ** indicates $\mathrm{p}<0.05$ compared to air. \# indicates $\mathrm{p}<0.05$ compared between CAP exposures. 


\section{Figure 16}

Heart Lung
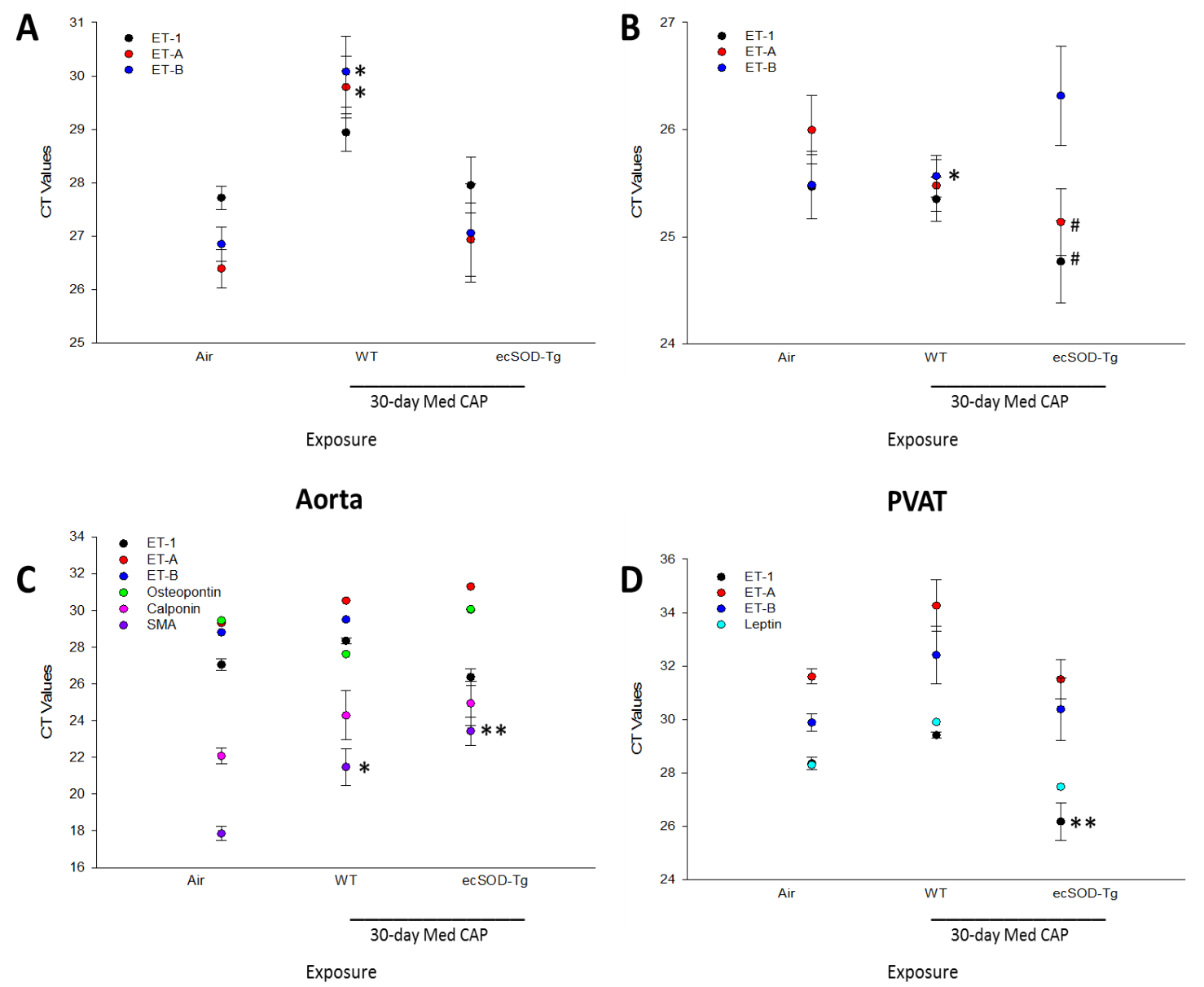

Figure 16: Comparison of $\mathrm{mRNA}$ expression of C57BL/6 and ecSOD-Tg

cardiopulmonary tissues after a chronic, medium concentration CAP exposure.

Comparison of mean \pm SD gene expression of the ET-1 system and other markers of interest in heart (A), lung (B), aorta (C), and PVAT (D) tissue after 30 days of CAP exposure. ecSOD-Tg mice had significantly increased gene expression of the ET-1 system in the lungs in comparison to $\mathrm{C} 57 \mathrm{BL} / 6$ mice in the same exposure. * indicates $\mathrm{p}$ $<0.05$ compared to air. * indicates $\mathrm{p}<0.05$ compared to air. $* *$ indicates $\mathrm{p}<0.05$ compared to air. \# indicates $\mathrm{p}<0.05$ compared between CAP exposures. 


\section{DISCUSSION AND CONCLUSIONS}

\section{HUMAN STUDY}

We conducted a case-crossover assessment of the association between $\mathrm{PM}_{2.5}$ exposure, ET-1, and EPC levels in a young, healthy cohort. We found that higher ET-1 levels were found on days with higher environmental temperature but lower relative humidity and barometric pressure. In an adjusted analysis of ET-1 and measured blood parameters, we found that platelet-monocyte aggregates, interleukin 6, albumin, and total plasma protein were positively associated with ET-1 levels, while white blood cell count was negatively associated with ET-1 levels.

Although not many studies have been performed relating ET-1 levels with these environmental factors, Kruse et al. (154) report seasonal variation in ET-1 levels, with the highest concentrations measured in July and the lowest in January. Although this study also examined the effects of relative humidity on ET-1 and other plasma parameters, there was no significant variation of relative humidity between the seasons and no association seen with ET-1 (154). Other studies have reported an inverse relationship between temperature and blood pressure, which can be altered by changes in the ET-1 system $(72-76,155,156)$. However, these studies were performed in older (154) or diseased (156) cohorts or using indoor temperature measurements rather than ambient temperature (155), which may explain the different results. As in our study, studies in healthy school children relating blood pressure and ambient temperature saw increases in 
blood pressure in colder months, with these changes likely related to changes in ET-1 $(157,158)$. Nevertheless, all of these studies, regardless of outcome, examined temperature over a period of several months spanning multiple seasons, whereas our study only occurred between January and March of 2009, as inversions only occur within the winter months. A longer study unrelated to $\mathrm{PM}_{2.5}$ would likely allow for a better understanding of the relationship between ET-1 and environmental factors.

The development of inflammation within the vasculature has been proposed as one mechanism through which air pollution may contribute to the development of CVD (12). ET-1 has been shown to be involved in the regulation of a number of inflammatory mediators $(55,81,94,95,104,111,138,159,160)$ and is known to contribute to downstream inflammation via the development of endothelium dysfunction (42). We found a significant positive association between ET-1 level and interleukin 6, which is a cardiovascular indicator of inflammation. We did not, however, see any association with hsCRP, which is the most common indicator of inflammation and which has been shown to be increased with $\mathrm{PM}_{2.5}$ exposure (104). Multiple studies have reported a relationship between hsCRP and ET- 1 levels (111, 138, 161-164). Jung et al. (138) found a significant correlation between ET-1 and hsCRP levels in patients with type 2 diabetes mellitus microalbuminuria, and Calderon-Garciduenas and colleagues (111) reported a similar association in a young, clinically healthy cohort from Mexico City. Our lack of an association may be due to the periodic nature of the Utah inversions; the positive associations found in the other cohorts may be linked to the pervasive high $\mathrm{PM}_{2.5}$ exposure of the study subjects, while our subjects were only subjected to abnormally high 
levels for a short period. Additional studies of cohorts exposed to high levels of $\mathrm{PM}_{2.5}$ for varying durations are needed to clarify this discrepancy.

White blood cell count is used as another marker of inflammatory status. White blood cell accumulation and transformation play a significant role in the development of endothelial dysfunction $(12,32)$ and the subsequent development of atherosclerosis $(12$, 32, 81, 165, 166). Diehl et al. (165) report a positive association between increased white blood cell count and vasoconstrictive activity of ET-1, which contradicts our finding of a negative association between ET-1 level and white blood cell count. This difference could be due to the type of ET-1 assessment; our results were based on endogenous measurements of ET-1, while Diehl's finding were based on changes in forearm blood flow in response to intra-brachial infusion of ET-1. Furthermore, the individuals that participated in our study were much younger than the ones enrolled in Diehl's study (1826 years old versus 53-57 years old, respectively) and were healthier in terms of BMI status. The subject characteristics of the older cohort show that all of the participants would be considered overweight based on the CDC's definition of standard weight status categories (165), and white blood cell count has been shown to be increased in overweight and obese individuals $(167,168)$. Thus, confounding factors such as weight and age could be contributing to the variation in results seen here. Expanding the study in Utah to include a greater diversity of individuals may enable us to relate ET-1 with white blood cell count more conclusively.

Regressions between the blood parameters and $\mathrm{PM}_{2.5}$ in an initial study of this cohort found significantly positive correlations with platelet-monocyte aggregates, high density lipoprotein cholesterol, total plasma protein, and nonalbumin protein (131). In 
looking at ET-1 and these parameters, positive associations were seen between ET-1 and platelet-monocyte aggregates, albumin, and total plasma protein, indicating that these factors may be influenced by $\mathrm{PM}_{2.5}$ exposure, changes in ET-1 levels, or perhaps both.

Platelet-monocyte aggregates are used as clinical indicators of thrombosis, while albumin is used as an indicator of blood pressure. Total plasma protein can provide information on both of these measures. ET-1 is a potent vasoconstrictor and plays an important role in the regulation of the vasculature. Imbalances in ET-1 and/or its counterpart, NO, initially causes endothelium dysfunction, which, as discussed above, is one of the underlying causes for a number of CVDs. It has been shown that increased blood pressure (71-76) and, chronically, the development of hypertension $(21,77,78)$ can result from increases in ET-1 related to endothelium dysfunction. Similarly, endothelium dysfunction has been associated with thrombosis $(90,96,169-171)$, specifically through decreased levels of bioactive NO $(169,170)$. Bioactive NO plays a role in inhibiting the activation of platelets, and thus its loss allows for increased platelet activation and aggregation, possibly leading to the development of thrombosis $(169,170)$. The development of endothelium dysfunction explains the positive associations between ET-1 and markers of both blood pressure and thrombosis seen in our study. There is a clear relationship between ET-1 and endothelium dysfunction, and even small changes in ET-1 could lead to downstream adverse cardiovascular effects triggered by changes in blood pressure, thrombotic factors, or a number of other elements within the vasculature. Future research should seek to establish associations between ET-1 and other commonly used clinical indicators of CVD that could allow for earlier detection of endothelial dysfunction. 
Endothelium dysfunction is theorized to be one of the initiating events in the development of CVD in response to air pollution exposure. Exposure to many types of air pollutants has been linked to different cardiovascular and pulmonary diseases, and detailed studies have linked specific pollutants to different health outcomes. Human studies have established significant cardiovascular effects in relation to DE and trafficrelated pollutants (28-30, 104, 113, 115-118), $\mathrm{PM}_{2.5}(19-27,111,112), \mathrm{CAP}(114)$, and occupation-specific air pollutants (119-122). A number of these studies have examined ET-1 in relation to exposure in hopes of clarifying the role between the two, but the subsequent results are conflicting. Some studies report increases in ET-1 levels (109, 111-113) with or without changes in functional measurements, while others report no change $(115,116)$ or even a decrease $(121)$ in levels. As previously described, Brook et al. (114), Mills et al. (115), and Langrish et al. (116) all failed to find significant changes in ET-1 or in commonly-used indicators of endothelium dysfunction in relation to controlled exposures, while Jarvela (121) found a decrease in ET-1 with exposure to welding fumes.

Our results, like Jarvela (121), found an inverse association between ET-1 and $\mathrm{PM}_{2.5}$ levels, with the lowest ET-1 levels corresponding to higher previous 24 hour $\mathrm{PM}_{2.5}$ levels for almost all subjects. These contradictory outcomes could have a number of explanations, including differences in pollution type, exposure length and concentration, and collection methods; small variations in the composition of $\mathrm{PM}_{2.5}$ could lead to varying changes in the vasculature and subsequently to varying health outcomes. Likewise, heterogeneous mixtures of pollutants could result in differences in results between studies. Jarvela (121) attributed the decrease in ET-1 to increased levels of 
nitric oxides within the welding fumes that could have an inhibitory impact on the production of ET-1 via its homeostatic balance with nitric oxide, as has been shown with direct exposure to nitric oxide gas in both endothelial cells $(172,173)$ and humans $(174)$. On the other hand, combustion-derived metals such as vanadium that have been found in high levels in ambient urban air pollution (41) have been shown to increase vasoconstriction, both generally $(175,176)$ and in relation to increased ET-1 $(177,178)$; this fits data seen in studies with combustion-related pollutant exposures (111-113). Thus, the particular composition of the exposure could significantly impact the outcomes of air pollution exposure in relation to ET-1.

Furthermore, because ET-1 is largely released abluminally, plasma levels may not accurately reflect the amount of ET-1 produced in response to air pollution exposures, and thus studies utilizing plasma measurements may vary due to basic collection and measurements methods. Future studies, therefore, should seek to standardize exposure protocols in terms of analyzing the composition of exposure pollutants and in regards to the collection and measurement of samples. This would allow for assessments of changes in ET-1 between truly comparable studies and would hopefully allow for a more accurate evaluation of the role of ET-1 in response to air pollution exposures.

High levels of $\mathrm{PM}_{2.5}$ exposure have been shown to decrease circulating EPC levels in humans, as shown in the original analysis of this study (131). EPC levels are known to decrease with increasing CVD risk and progression $(131,132,179,180)$, and as $\mathrm{PM}_{2.5}$ exposure increases the risk of developing CVD, it can be construed that changes in EPC levels can result from $\mathrm{PM}_{2.5}$ exposure and lead to downstream vascular injury. Few studies have looked at the relationship between ET-1 and EPCs $(130,138,139,181)$, and 
none have looked in a healthy human cohort as in our study. We found no association between ET-1 and the majority of the EPC populations assessed. However, there was a significant positive association between ET-1 and EPC-4 $\left(\mathrm{CD} 31^{+} / 34^{+} / 45^{+} / \mathrm{ACC} 33^{+}\right)$. This particular population also had the strongest statistical correlation seen in the negative association between $\mathrm{PM}_{2.5}$ and circulating EPC levels (131), and the exclusivity of an association with ET-1 levels may indicate a unique role of this EPC population in vascular injury and changes in relation to $\mathrm{PM}_{2.5}$ exposure. This assessment may also indicate a role of ET-1 in regulating the levels of specific EPC populations, and it may also suggest a potential feedback or reciprocal relationship between ET-1 and select EPCs. Further investigation is required to determine what is contributing to this association between ET-1 and EPC-4 and what role in particular ET-1 may have on the regulation of this population. Future studies should examine a larger population of EPCs and assess their relationship to ET-1 to determine if there are any other associations between the populations and the vasoconstrictor.

In summary, this human study shows that ET-1 is associated with a number of vascular markers related to cardiovascular outcomes, particularly those related to inflammation, thrombosis, blood pressure, and overall vascular injury. Changes in these markers are used clinically to indicate the development of CVD, and they inherently reflect changes in the functioning of the vascular endothelium. ET-1 has been shown to be upregulated in a number of disease states related to endothelium dysfunction, and although exposure to air pollutants such as $\mathrm{PM}_{2.5}$ are hypothesized to induce CVD via the development of endothelium dysfunction, research has indicated mixed results in terms of the relationship between ET-1 and $\mathrm{PM}_{2.5}$. A likely explanation for this discrepancy is the 
varying exposure types and the differences in collection and measurement methods. The inverse association between ET-1 and $\mathrm{PM}_{2.5}$ seen here may indicate decreased production of ET-1 in relation to exposure or could signify an increased clearance of the peptide from the vasculature. ET-1's lack of association with five of the six measured EPC populations would seem to indicate no relationship between the two markers, but the positive association specifically with EPC-4 $\left(\mathrm{CD} 31^{+} / 34^{+} / 45^{+} / \mathrm{ACC} 133^{+}\right)$reveals a unique link that may imply regulation of this cell type by ET-1. Future direction should assess changes in a larger, more diverse cohort through a variety of $\mathrm{PM}_{2.5}$ levels to better assess the relationship between ET-1, vascular changes, and pollution exposure. A better understanding of this relationship could allow for the use of ET-1 as a diagnostic tool and could help develop therapeutics to diminish the impact of alterations in the ET-1 system on cardiovascular health.

\section{ANIMAL STUDIES}

We performed $\mathrm{PM}_{2.5}$ exposures in two murine models to assess the effect of $\mathrm{PM}_{2.5}$ exposure on the gene expression of the ET-1 system in the cardiopulmonary tissues. Our results showed significant changes in the expression of specific components of the ET-1 system with CAP exposure. These changes varied between the tissues and were largely associated with the specific concentration and/or duration of the exposure. There were also significant differences seen between the tissues based on the mouse model.

Few studies have examined changes in the murine ET-1 system in relation to air pollution exposure. Increases in aortic ET-1 mRNA expression have been noted in response to both GEE and DE $(31,105,123)$, and greater ET-1-induced vasoconstriction 
has been measured after exposure to DE (124). Changes in ET-1 receptor levels have not been well assessed in murine models, and there has been little assessment of the ET-1 system in relation to exposures of different durations and concentrations. Our study showed changes in the gene expression of various components of the system between air and CAP exposure regardless of exposure duration or concentration or mouse model. Although not all of these changes were significant, the potency of ET-1's vasoconstrictive effect and its role in maintaining vascular homeostasis means that even small changes in the levels of the peptide or its receptors could have a significant impact on proper endothelial function and on downstream cardiovascular and pulmonary injury.

Despite the changes seen within individual exposures, comparisons in C57BL/6 mice between corresponding exposures revealed that an acute CAP exposure with a higher $\mathrm{PM}_{2.5}$ concentration did not have significantly more of an impact on gene expression of the ET-1 system in the tissues overall than did a similarly acute exposure of a lower concentration. On the other hand, although significant changes were seen in response to the acute, higher concentration exposure, an exposure similar in concentration but longer in duration ( 9 days vs. 30 days, respectively) showed greater overall decreases in the ET-1 system gene expression in each tissue examined. This may indicate that duration of exposure plays a greater impact on the integrity of the vasculature of the cardiopulmonary tissues than does the concentration of the exposure. Although it is well known that even short periods of exposure to high levels of air pollution can have many negative health impacts $(8,131,182,183)$, acute but chronic exposures may have a more important role in the development of chronic conditions (12, $32,182,184,185)$. Additional studies are needed to measure the protein levels of these 
markers in response to exposure, which would give us a true assessment of changes in the ET-1 system and in other systemic markers that could lead to changes in vascular function. Furthermore, future studies should continue to utilize varying concentrations and durations of exposure to produce dose- and duration-response curves that allow for a better understanding of both short-term effects of high level exposures and the cumulative effect of repeated exposures.

The use of ecSOD-Tg mice in our exposure studies explored the potential benefit of overexpression of the antioxidant enzyme ecSOD as a protective mechanism against $\mathrm{PM}_{2.5}$ exposure. ecSOD plays a significant role in scavenging superoxide anions, whose presence has been linked to a number of disease states (146, 186-189). Increased levels of ecSOD have been shown to be protective in both cardiac (188) and pulmonary (149, 190) tissues. Our study indicates that, in the lungs, this protective effect may be due to increased levels of the $\mathrm{ET}_{\mathrm{B}}$ receptor. After an acute, low $\mathrm{PM}_{2.5}$ exposure, the gene expression of the $\mathrm{ET}_{\mathrm{B}}$ receptor was significantly increased. As the $\mathrm{ET}_{\mathrm{B}}$ receptor is responsible for clearance of ET-1 from the vasculature $(57,64-67)$, the evidence suggests that any $\mathrm{PM}_{2.5}$-induced ET-1 production is likely quickly rendered ineffective due to rapid binding and removal. As there was no concurrently significant increase in the gene expression of the $\mathrm{ET}_{\mathrm{A}}$ receptor, there is no indication that there would be increased activation of the downstream vasoconstriction pathway, so there would seem to be no increased risk of the cardiopulmonary diseases associated with $\mathrm{PM}_{2.5}$ exposure. In fact, since ET-1 would be having a decreased vasoconstrictive response to exposure, there may actually be a decreased risk with a short term, low concentration exposure. However, this increase in $\mathrm{ET}_{\mathrm{B}}$ gene expression was not seen after a chronic, higher dose 
exposure, indicating that this protective effect may be lost either over time or at higher concentrations of exposure. Future exposures at varying concentrations and duration using ecSOD-Tg mice would help clarify the nature of this seemingly protective increase in the $\mathrm{ET}_{\mathrm{B}}$ receptor.

Similarly, the impact of exposure on smooth muscle actin in the aorta was dramatically different between the two exposure durations, although not all these changes were significant. Smooth muscle actin is a marker of differentiated smooth muscle cells (191, 192), and it plays a major role in the contraction of smooth muscle cells (191-194). Lack of this contractile ability can lead to vascular stiffness, which can lead to conditions including hypertension and atherosclerosis $(192,195)$, as well as to dysregulated airway reactivity $(196,197)$. Exposure to certain types of air pollutants has been shown to increase vascular stiffness (28), although similar exposures have been shown to increase airway contractibility $(39,104-106)$. Our study, however, only examined smooth muscle actin expression in the aorta and thus could only assess the vascular changes. After 9 days, gene expression of aortic smooth muscle actin was significantly increased, but expression was then significantly decreased after 30 days. Based on the combined results, it can be hypothesized that the duration of the exposure has a greater impact on the expression of smooth muscle actin than does the concentration of the exposure or the strain of mouse. These results fit functional data in our lab (149) that short term $\mathrm{PM}_{2.5}$ exposure increases aortic contractility, similar to the hyperreactivity seen in the airways during asthma attacks $(39,196,197)$. This is perhaps related to the measured increase in smooth muscle actin expression and a logical increase in downstream aortic contractility. Likewise, the decreased gene expression in smooth muscle actin seen after 30 days may 
be expected to cause aortic hypocontractility, which has also been demonstrated in functional studies in our lab (149). These dramatic changes in contractile ability are perhaps the result of changes in the contractile apparatus of the vascular smooth muscle cells themselves as a result of air pollution exposure. Furthermore, as smooth muscle actin is a marker of differentiated smooth muscle cells, its decrease likely indicates that smooth muscle cells are becoming dedifferentiated, which is a sign of endothelium dysfunction and is one of the earliest signs of atherosclerosis $(191,198,199)$. Additional studies will focus on study of these early gene and phenotypic changes and correlated functional alterations in hopes of identifying possible interventions to deter the beginnings of atherosclerotic development.

The results seen in the PVAT may also indicate the beginning of a chronic disease. In both C57BL/6 and ecSOD-Tg mice, ET-1 and leptin showed increased gene expression with specific exposures. Leptin is a hormonal indicator of the body's fed status; that is, leptin is secreted by adipose tissue and serves as a signal to decrease appetite and increase energy expenditure (200-202). Paradoxically, although leptin is meant to suppress one's appetite, significantly increased levels are consistently measured in obese individuals (200-204). This condition has been termed leptin resistance, in which the body fails to respond to increased leptin levels and continues to signal for more energy despite an already obese weight status (200-202). Levels of ET-1 have also been noted to be increased in obese individuals $(205,206)$, with increased endothelium dysfunction (207) and enhanced ET-1-dependent vasoconstriction $(207,208)$ seen in this group compared to normal weight counterparts. Thus, taken together, these increases of both ET-1 and leptin seen in this study seem to denote that $\mathrm{PM}_{2.5}$ exposure is contributing 
to the development of leptin resistance. And in fact, several epidemiological studies have linked exposure to air pollutants to increases in BMI (209-211). The results of this study may also support the hypothesis that leptin stimulates ET-1 release (212-214), which could help explain the increased incidence of cardiopulmonary conditions seen in obese individuals (215-220). Future studies should work towards a better understanding of the possible relationship between leptin, ET-1, and $\mathrm{PM}_{2.5}$ in hopes of providing relevant data that could be used to better understand and possibly impede the ever-growing obesity epidemic.

\section{CONCLUSIONS}

Taken together, the results of our human study show that young, healthy individuals exposed to air pollution experience changes in the vasculature that can potentially lead to downstream cardiovascular problems. ET-1 was associated with environmental factors as well as a number of markers of thrombosis, inflammation, and blood pressure, implicating ET-1 as a likely mediator in the mechanism through which $\mathrm{PM}_{2.5}$ causes CVD. Surprisingly, ET-1 levels were seen to significantly decrease with increasing $\mathrm{PM}_{2.5}$ concentration. While most studies report an increase in ET-1 with exposure, exposures of varying compositions and durations have shown a fair amount of variability in the changes induced in the ET-1 system. Thus, although we did not see an increase in ET-1 with high $\mathrm{PM}_{2.5}$ exposure as we had expected, the significantly inverse association between the two factors indicates that ET-1 production is altered by exposure to air pollution. Combined with the positive association between ET-1 and EPC-4 $\left(\mathrm{CD} 31^{+} / 34^{+} / 45^{+} / \mathrm{ACC} 133^{+}\right)$and the strongly inverse association between EPC-4 levels 
and $\mathrm{PM}_{2.5}$, the data likely indicates that ET-1 is, in fact, a mediator between air pollution exposure and the development of CVD.

There are a number of both strengths and limitations within this study. Although our study population was small, the population possessed few confounding health factors that could possibly have affected the results. Our population may therefore not have reflected the general population, but the lack of confounding health factors allowed for a more accurate assessment of the relationship between ET-1, PM 2.5 , and EPCs. In terms of EPC measurement, flow cytometry is one of the quickest and most accurate methods for measuring circulating levels of EPCs, as it utilizes antigenic markers (CD31 ${ }^{+}, \mathrm{CD}_{3} 4^{+}$, $\mathrm{CD} 45^{+/ \mathrm{dim}}, \mathrm{AC} 133^{+/-}$) highly specific to EPCs to make the counts. There is some potential bias in the measurement of the EPCs via the gating of the cells, as the process may appear rather arbitrary and may vary between investigators. Therefore, a single investigator both directed and verified the gating of the EPCs to minimize the potential for different gating strategies. Furthermore, as ET-1 is largely released abluminally from the circulation, measuring ET-1 in the plasma may not accurately reflect changes at a more local level. Plasma is, however, the easiest and most common sample used to measure ET-1 in humans, and we therefore assessed ET-1 in the plasma as well to allow for comparison to similar studies.

Future human studies should work towards increasing the sample size of the cohort in any single year. A longitudinal study of past participants who still meet the enrollment criteria should also be performed to assess how the body adapts or fails to adapt to this repeated seasonal exposures. It would also be interesting to assess ET-1, EPCs, and the other blood parameters in this cohort during different seasons to better 
study the influence of temperature and other environmental factors on the relationship between air pollution exposure and CVD. Additional EPC populations should also be examined; our lab currently has fifteen EPC populations that have been used to assess changes in the vasculature, and it would be important to see if there is an association between ET-1 and any of these other populations. It would also be beneficial to examine the association between ET-1 and the equivalent of EPCs in murine models. Mice represent a relevant and available model of human physiology but allow for a wider range of treatments and mechanistic studies than human subjects. Using mice, therefore, to study ET-1 and EPCs would allow for the use of interventions that could possibly shed more light on the relationship between these markers on a more mechanistic level.

The results of our animal studies overall reveal that exposure to $\mathrm{PM}_{2.5}$ causes significant changes in the gene expression of the ET-1 system of the cardiopulmonary tissues. These changes were dependent on the varying exposure durations and concentrations and with varying genetic backgrounds of the models. The ET-1 system in C57BL/6 mice showed a number of both significant increases and decreases in gene expression depending on the tissue and the specific exposure, but a greater response was seen in the chronic exposures regardless of the concentration level. This finding supports evidence showing that chronic air pollution exposures, whether at low or high levels, can cause vascular changes and lead to the development of chronic health conditions, cardiopulmonary or otherwise. Our findings in the tissues of ecSOD-Tg mice support our hypothesis that that the upregulation of this antioxidant enzyme prevents ROS-related changes, at least after an acute, low-dose exposure. The significant increase in the gene expression of the $\mathrm{ET}_{\mathrm{B}}$ receptor seen in the ecSOD-Tg lungs may serve as a protective 
mechanism by which $\mathrm{PM}_{2.5}$-induced increases in ET-1 levels are mitigated by increased clearance. However, this protective effect was not seen in a chronic, higher-dose exposure, so it would seem that, given that the increase in $\mathrm{ET}_{\mathrm{B}}$ is a protective effect conferred by the increase in the ecSOD enzyme, the overexpression of pulmonary ecSOD is not able to prevent ROS-related injury perpetually. Nonetheless, the indication of any sort of protective effect could play a significant role in the understanding of the mechanism through which air pollution causes downstream cardiopulmonary diseases. Furthermore, the changes in smooth muscle actin gene expression in the aorta and in ET1 and leptin in the PVAT seem to be early indicators of the development of chronic diseases: atherosclerosis and obesity, respectively. ET-1 has been hypothesized to play a role in both of these conditions, and our studies in these murine models seem to indicate that air pollution exposure may be contributing to the changes in the ET- 1 system that subsequently contribute to disease development.

Our results, however, must be viewed in light of both the strengths and weaknesses of the study overall. In terms of the exposures themselves, we have no control over ambient $\mathrm{PM}_{2.5}$ levels and thus we cannot control the concentration of any given exposure. We are also limited in the number of mice we can expose during any single experiment; together, these two factors have the potential to reduce the sample size for the groups at varying exposure concentrations and durations. Exposures are thus run with as many mice as possible and as often as possible to increase the likelihood of conducting exposures at varying concentrations. When two or more exposures have the same duration and a very similar overall concentration, we have combined the samples into a single exposure level in order to increase sample size. 
In regards to assessing changes within the ET-1 system in response to exposure, qRT-PCR was used to measure the gene expression of ET-1 and its two receptors, as well as other relevant markers, in each of the tissues. qRT-PCR is problematic in that it measures gene expression and not the actual gene product, and changes in expression may not be reflected in actual production. Also, there is always the possibility of genomic contamination in RNA prepared from the tissues, and with dilution of the cDNA samples in preparation for qRT-PCR, any contamination will give a larger signal and lead to falsely increased CT values. Furthermore, as tissues are composed of a variety of cell types, we cannot attribute any specific cell type for the changes seen in the ET-1 system.

Future studies in murine models will focus primarily on addressing the limitations of the current study. Continuing exposures will allow for both increased sample size and a wider range of exposure concentrations and durations. Gathering data over a wider range of conditions will allow us to more accurately measure changes in the ET-1 system related to specific levels of $\mathrm{PM}_{2.5}$ or to particular time points; such results could help provide more detailed information on changes in the cardiovascular and respiratory systems related to air pollution exposure and could potentially contribute to larger undertakings seeking to decrease the incidence of pollution-related CVD. Protein measurement of the ET-1 system, as well as functional data in exposed mice, would additionally provide more concrete evidence for the role of ET-1 in the interplay between air pollution exposure and disease development. Additionally, measurement of EPC levels in exposed mice would provide evidence of vascular injury, and these levels could then be associated with plasma levels of ET-1, as was done in the human study. The use of pharmacological interventions such as ET receptor inhibitors could also help clarify 
ET-1's role in the overall mechanism of exposure as well as the role of ET-1 in the regulation of EPCs.

It would also be beneficial to assess ET-1 changes in female mice to determine how sex plays a role in the impact of air pollution on CVD and pulmonary conditions. The vast majority of pollution exposure studies use only male models, which fails to take into account that heart disease is the leading cause of death for females in the United States (221) and that women have been found to be more susceptible to certain cardiopulmonary conditions than men (222). Pulmonary hypertension, for example, has a female-male ratio of 2.7:1 (222), and development and exacerbation of the disease has been linked to air pollution exposure $(223,224)$. Accordingly, exposure studies in females are needed to explain this phenomenon and to help curtail the growing incidence of CVD and pulmonary disease.

In summary, these studies examine an important mediator in the mechanism through which air pollution exposure causes CVD. Our human data reveal a significant association between ET-1 and markers of change and injury in the vasculature and between ET-1 and $\mathrm{PM}_{2.5}$, thus providing evidence that $\mathrm{PM}_{2.5}$-induced changes in ET-1 can have a significant effect on the health of the vascular endothelium. Our exposures in C57BL/6 mice showed that expression of ET-1 system genes can be significantly altered by a variety of exposure conditions, although chronic exposures seem to have a greater impact and may, thus, have a more negative impact on overall health. Our interventional study utilizing mice with pulmonary overexpression of the antioxidant enzyme ecSOD revealed a potentially novel protective effect in the lungs via increased gene expression of the ET-1 clearance receptor, $\mathrm{ET}_{\mathrm{B}}$. Although this increase was lost with increasing 
concentration and duration of exposure, the initial change still shows that decreasing $\mathrm{PM}_{2.5}$-induced ROS has the capability of preventing downstream injury. Overall results of this investigation provide insights into the role of ET-1 in the vasculature in response to $\mathrm{PM}_{2.5}$ exposure as well as its relationship with clinical indicators of vascular changes. The results presented here could be used to drive future investigations into the link between air pollution exposure and CVD, pulmonary diseases, and other chronic conditions and could also be used as a basis for potential interventional therapies for diseases caused or exacerbated by environmental exposure. 


\section{REFERENCES}

1. Health Topics: Air Pollution. 2014. Available from: www.who.int. Accessed June 17, 2014.

2. Finch, J. and Conklin, D.J. (2016). Air Pollution-Induced Vascular Dysfunction: Potential Role of Endothelin-1 (ET-1) System. Cardiovasc Toxicol 16: 260-275.

3. Latest Findings of National Air Quality: Status and Trends Through 2006. 2008. Available from: www.epa.gov. Accessed June 17, 2014.

4. Rubin, E.S. (2013). Climate Change, Technology Innovation, and the Future of Coal. Cornerstone 1: 37-43.

5. Progress Cleaning the Air and Improving People's Health. 2014. Available from: www.epa.gov. Accessed June 17, 2014.

6. 7 Million Premature Deaths Annually Linked to Air Pollution. 2014. Available from: www.who.int. Accessed June 17, 2014.

7. Heart Disease Facts. 2014. Available from: www.cdc.gov. Accessed July 16, 2014.

8. Nawrot, T.S., Perez, L., Künzli, N., Munters, E. and Nemery, B. Public health importance of triggers of myocardial infarction: a comparative risk assessment. The Lancet 377: 732-740.

9. Brook, R.D., Franklin, B., Cascio, W., Hong, Y., Howard, G., Lipsett, M., Luepker, R., Mittleman, M., Samet, J., Smith, S.C., Jr., Tager, I., Expert Panel on, P. and Prevention Science of the American Heart, A. (2004). Air pollution and cardiovascular disease: a statement for healthcare professionals from the Expert Panel on Population and Prevention Science of the American Heart Association. Circulation 109: 2655-2671.

10. Bhatnagar, A. (2006). Environmental cardiology: studying mechanistic links between pollution and heart disease. Circulation research 99: 692-705.

11. Pope lii, C.A. and Dockery, D.W. (2006). Health Effects of Fine Particulate Air Pollution: Lines that Connect. Journal of the Air \& Waste Management Association (Air \& Waste Management Association) 56: 709-742.

12. Brook, R.D., Rajagopalan, S., Pope, C.A., 3rd, Brook, J.R., Bhatnagar, A., Diez-Roux, A.V., Holguin, F., Hong, Y., Luepker, R.V., Mittleman, M.A., Peters, A., Siscovick, D., Smith, S.C., Jr., Whitsel, L., Kaufman, J.D., American Heart Association Council on, E., Prevention, C.o.t.K.i.C.D., Council on Nutrition, P.A. and Metabolism. (2010). Particulate matter air pollution and cardiovascular disease: An update to the scientific statement from the American Heart Association. Circulation 121: 2331-2378.

13. Shah, A.S., Langrish, J.P., Nair, H., McAllister, D.A., Hunter, A.L., Donaldson, K., Newby, D.E. and Mills, N.L. (2013). Global association of air pollution and heart failure: a systematic review and meta-analysis. Lancet 382: 1039-1048.

14. Dockery, D.W., Pope, C.A., Xu, X., Spengler, J.D., Ware, J.H., Fay, M.E., Ferris, B.G. and Speizer, F.E. (1993). An Association between Air Pollution and Mortality in Six U.S. Cities. New England Journal of Medicine 329: 1753-1759.

15. Pope, C.A., 3rd, Burnett, R.T., Thurston, G.D., Thun, M.J., Calle, E.E., Krewski, D. and Godleski, J.J. (2004). Cardiovascular mortality and long-term exposure to particulate air 
pollution: epidemiological evidence of general pathophysiological pathways of disease. Circulation 109: 71-77.

16. Laden, F., Schwartz, J., Speizer, F.E. and Dockery, D.W. (2006). Reduction in fine particulate air pollution and mortality: Extended follow-up of the Harvard Six Cities study. American journal of respiratory and critical care medicine 173: 667-672.

17. Puett, R.C., Hart, J.E., Yanosky, J.D., Paciorek, C., Schwartz, J., Suh, H., Speizer, F.E. and Laden, F. (2009). Chronic Fine and Coarse Particulate Exposure, Mortality, and Coronary Heart Disease in the Nurses' Health Study. Environmental health perspectives 117: 1697-1701.

18. Lepeule, J., Laden, F., Dockery, D. and Schwartz, J. (2012). Chronic exposure to fine particles and mortality: an extended follow-up of the Harvard Six Cities study from 1974 to 2009. Environmental health perspectives 120: 965-970.

19. Van Hee, V.C., Adar, S.D., Szpiro, A.A., Barr, R.G., Bluemke, D.A., Diez Roux, A.V., Gill, E.A., Sheppard, L. and Kaufman, J.D. (2009). Exposure to traffic and left ventricular mass and function: the Multi-Ethnic Study of Atherosclerosis. American journal of respiratory and critical care medicine 179: 827-834.

20. Ibald-Mulli, A., Stieber, J., Wichmann, H., Koenig, W. and Peters, A. (2001). Effects of air pollution on blood pressure: a population-based approach. American Journal of Public Health 91: 571-577.

21. Auchincloss, A.H., Diez Roux, A.V., Dvonch, J.T., Brown, P.L., Barr, R.G., Daviglus, M.L., Goff, D.C., Kaufman, J.D. and O'Neill, M.S. (2008). Associations between recent exposure to ambient fine particulate matter and blood pressure in the Multi-ethnic Study of Atherosclerosis (MESA). Environmental health perspectives 116: 486-491.

22. Dvonch, J.T., Kannan, S., Schulz, A.J., Keeler, G.J., Mentz, G., House, J., Benjamin, A., Max, P., Bard, R.L. and Brook, R.D. (2009). Acute effects of ambient particulate matter on blood pressure: differential effects across urban communities. Hypertension 53: 853-859.

23. Langrish, J.P., Li, X., Wang, S., Lee, M.M.Y., Barnes, G.D., Miller, M.R., Cassee, F.R., Boon, N.A., Donaldson, K., Li, J., Li, L., Mills, N.L., Newby, D.E. and Jiang, L. (2012). Reducing Personal Exposure to Particulate Air Pollution Improves Cardiovascular Health in Patients with Coronary Heart Disease. Environmental health perspectives 120: 367-372.

24. Peters, A., Dockery, D.W., Muller, J.E. and Mittleman, M.A. (2001). Increased Particulate Air Pollution and the Triggering of Myocardial Infarction. Circulation 103: 2810-2815.

25. Adar, S.D., Sheppard, L., Vedal, S., Polak, J.F., Sampson, P.D., Diez Roux, A.V., Budoff, M., Jacobs, D.R., Jr., Barr, R.G., Watson, K. and Kaufman, J.D. (2013). Fine particulate air pollution and the progression of carotid intima-medial thickness: a prospective cohort study from the multi-ethnic study of atherosclerosis and air pollution. PLoS medicine 10: e1001430.

26. Wilker, E.H., Mittleman, M.A., Coull, B.A., Gryparis, A., Bots, M.L., Schwartz, J. and Sparrow, D. (2013). Long-term Exposure to Black Carbon and Carotid Intima-Media Thickness: The Normative Aging Study. Environmental health perspectives 121: 1061-1067.

27. Künzli, N., Jerrett, M., Garcia-Esteban, R., Basagaña, X., Beckermann, B., Gilliland, F., Medina, M., Peters, J., Hodis, H.N. and Mack, W.J. (2010). Ambient Air Pollution and the Progression of Atherosclerosis in Adults. PloS one 5: 1-10.

28. Lundback, M., Mills, N.L., Lucking, A., Barath, S., Donaldson, K., Newby, D.E., Sandstrom, T. and Blomberg, A. (2009). Experimental exposure to diesel exhaust increases arterial stiffness in man. Particle and fibre toxicology 6: 7.

29. Cosselman, K.E., Krishnan, R.M., Oron, A.P., Jansen, K., Peretz, A., Sullivan, J.H., Larson, T.V. and Kaufman, J.D. (2012). Blood pressure response to controlled diesel exhaust exposure in human subjects. Hypertension 59: 943-948. 
30. Medina-Ramon, M., Goldberg, R., Melly, S., Mittleman, M.A. and Schwartz, J. (2008). Residential exposure to traffic-related air pollution and survival after heart failure.

Environmental health perspectives 116: 481-485.

31. McDonald, J.D., Reed, M.D., Campen, M.J., Barrett, E.G., Seagrave, J. and Mauderly, J.L. (2007). Health effects of inhaled gasoline engine emissions. Inhalation toxicology 19 Suppl 1: 107-116.

32. Brook, R.D. and Rajagopalan, S. (2009). Particulate matter, air pollution, and blood pressure. Journal of the American Society of Hypertension : JASH 3: 332-350.

33. Peters, A. (2009). Air quality and cardiovascular health: smoke and pollution matter. Circulation 120: 924-927.

34. Sun, Q., Hong, X. and Wold, L.E. (2010). Cardiovascular effects of ambient particulate air pollution exposure. Circulation 121: 2755-2765.

35. Meng, Q., Richmond-Bryant, J., Lu, S.-E., Buckley, B., Welsh, W.J., Whitsel, E.A., Hanna, A., Yeatts, K.B., Warren, J., Herring, A.H. and Xiu, A. (2013). Cardiovascular Outcomes and the Physical and Chemical Properties of Metal lons Found in Particulate Matter Air Pollution: A QICAR Study. Environmental health perspectives 121: 558-564.

36. Uzoigwe, J.C., Prum, T., Bresnahan, E. and Garelnabi, M. (2013). The Emerging Role of Outdoor and Indoor Air Pollution in Cardiovascular Disease. North American Journal of Medical Sciences 5: 445-453.

37. Lerman, A. and Zeiher, A.M. (2005). Endothelial Function: Cardiac Events. Circulation 111: 363-368.

38. Leppert, J., Ringqvist, A., Karlberg, B.E. and Ringqvist, I. (1998). Whole-body cooling increases plasma endothelin-1 levels in women with primary Raynaud's phenomenon. Clinical physiology (Oxford, England) 18: 420-425.

39. Spiropoulos, K., Trakada, G., Nikolaou, E., Prodromakis, E., Efremidis, G., Pouli, A. and Koniavitou, A. (2003). Endothelin-1 levels in the pathophysiology of chronic obstructive pulmonary disease and bronchial asthma. Respiratory Medicine 97: 983-989.

40. O'Neill, M.S., Veves, A., Zanobetti, A., Sarnat, J.A., Gold, D.R., Economides, P.A., Horton, E.S. and Schwartz, J. (2005). Diabetes enhances vulnerability to particulate air pollutionassociated impairment in vascular reactivity and endothelial function. Circulation 111: 29132920.

41. Calderon-Garciduenas, L., Franco-Lira, M., Torres-Jardon, R., Henriquez-Roldan, C., Barragan-Mejia, G., Valencia-Salazar, G., Gonzalez-Maciel, A., Reynoso-Robles, R., VillarrealCalderon, R. and Reed, W. (2007). Pediatric respiratory and systemic effects of chronic air pollution exposure: nose, lung, heart, and brain pathology. Toxicologic pathology 35: 154-162. 42. Cellini, M., Strobbe, E., Gizzi, C., Balducci, N., Toschi, P.G. and Campos, E.C. (2012). Endothelin-1 plasma levels and vascular endothelial dysfunction in primary open angle glaucoma. Life sciences 91: 699-702.

43. Toda, N. and Okamura, T. (2013). Obesity impairs vasodilatation and blood flow increase mediated by endothelial nitric oxide: An overview. Journal of Clinical Pharmacology 53: 12281239.

44. Furchgott, R.F. and Zawadzki, J.V. (1980). The obligatory role of endothelial cells in the relaxation of arterial smooth muscle by acetylcholine. Nature 288: 373-376.

45. Palmer, R.M., Ferrige, A.G. and Moncada, S. (1987). Nitric oxide release accounts for the biological activity of endothelium-derived relaxing factor. Nature 327: 524-526.

46. Yanagisawa, M., Kurihara, H., Kimura, S., Tomobe, Y., Kobayashi, M., Mitsui, Y., Yazaki, Y., Goto, K. and Masaki, T. (1988). A novel potent vasoconstrictor peptide produced by vascular endothelial cells. Nature 332: 411-415. 
47. Battistini, B., D'Orleans-Juste, P. and Sirois, P. (1993). Endothelins: circulating plasma levels and presence in other biologic fluids. Laboratory investigation; a journal of technical methods and pathology 68: 600-628.

48. Rubanyi, G.M. and Polokoff, M.A. (1994). Endothelins: molecular biology, biochemistry, pharmacology, physiology, and pathophysiology. Pharmacological reviews 46: 325-415.

49. Levin, E.R. (1995). Endothelins. New England Journal of Medicine 333: 356-363.

50. Luscher, T.F. and Barton, M. (2000). Endothelins and Endothelin Receptor Antagonists : Therapeutic Considerations for a Novel Class of Cardiovascular Drugs. Circulation 102: 24342440.

51. Fagan, K.A., McMurtry, I.F. and Rodman, D.M. (2001). Role of endothelin-1 in lung disease. Respiratory research 2: 90-101.

52. Barton, M. and Yanagisawa, M. (2008). Endothelin: 20 years from discovery to therapy. Canadian journal of physiology and pharmacology 86: 485-498.

53. Saida, K., Mitsui, Y. and Ishida, N. (1989). A novel peptide, vasoactive intestinal contractor, of a new (endothelin) peptide family. Molecular cloning, expression, and biological activity. The Journal of biological chemistry 264: 14613-14616.

54. Cunningham, M.E., Huribal, M., Bala, R.J. and McMillen, M.A. (1997). Endothelin-1 and endothelin-4 stimulate monocyte production of cytokines. Critical care medicine 25: 958-964.

55. Kedzierski, R.M. and Yanagisawa, M. (2001). Endothelin system: the double-edged sword in health and disease. Annual review of pharmacology and toxicology 41: 851-876.

56. Howard, P.G., Plumpton, C. and Davenport, A.P. (1992). Anatomical localization and pharmacological activity of mature endothelins and their precursors in human vascular tissue. Journal of hypertension 10: 1379-1386.

57. Ohkita, M., Tawa, M., Kitada, K. and Matsumura, Y. (2012). Pathophysiological Roles of Endothelin Receptors in Cardiovascular Diseases. Journal of Pharmacological Sciences 119: 302313.

58. Dhaun, N., Webb, D.J. and Kluth, D.C. (2012). Endothelin-1 and the kidney--beyond BP. British journal of pharmacology 167: 720-731.

59. Brunner, F., Bras-Silva, C., Cerdeira, A.S. and Leite-Moreira, A.F. (2006). Cardiovascular endothelins: essential regulators of cardiovascular homeostasis. Pharmacol Ther 111: 508-531. 60. Kurihara, H., Yoshizumi, M., Sugiyama, T., Takaku, F., Yanagisawa, M., Masaki, T., Hamaoki, M., Kato, H. and Yazaki, Y. (1989). Transforming growth factor-beta stimulates the expression of endothelin mRNA by vascular endothelial cells. Biochemical and biophysical research communications 159: 1435-1440.

61. Emori, T., Y, H., Imai, T., Ohta, K., Kanno, K., Equchi, S. and Marumo, F. (1992). Cellular mechanism of thrombin on endothelin-1 biosynthesis and release in bovine endothelial cell. Biochemical Pharmacology 44: 2409-2411.

62. Chen, G.F. and Sun, Z. (2006). Effects of chronic cold exposure on the endothelin system. J Appl Physiol 100: 1719-1726.

63. Mazzuca, M.Q. and Khalil, R.A. (2012). Vascular endothelin receptor type B: Structure, function and dysregulation in vascular disease. Biochemical Pharmacology 84: 147-162.

64. Bremnes, T., Paasche, J.D., Mehlum, A., Sandberg, C., Bremnes, B. and Attramadal, H. (2000). Regulation and intracellular trafficking pathways of the endothelin receptors. The Journal of biological chemistry 275: 17596-17604.

65. Ihling, C., Szombathy, T., Bohrmann, B., Brockhaus, M., Schaefer, H.E. and Loeffler, B.M. (2001). Coexpression of Endothelin-Converting Enzyme-1 and Endothelin-1 in Different Stages of Human Atherosclerosis. Circulation 104: 864-869. 
66. Vierhapper, H., Wagner, O., Nowotny, P. and Waldhausl, W. (1990). Effect of endothelin1 in man. Circulation 81: 1415-1418.

67. Thorin, E. and Clozel, M. (2010). The cardiovascular physiology and pharmacology of endothelin-1. Advances in pharmacology (San Diego, Calif.) 60: 1-26.

68. Battistini, B. and Dussault, P. (1998). Biosynthesis, distribution and metabolism of endothelins in the pulmonary system. Pulmonary pharmacology \& therapeutics 11: 79-88.

69. Kastin, A. (2013). Handbook of Biologically Active Peptides. Elsevier Science.

70. Moreland, S., McMullen, D.M., Delaney, C.L., Lee, V.G. and Hunt, J.T. (1992). Venous smooth muscle contains vasoconstrictor ETB-like receptors. Biochemical and biophysical research communications 184: 100-106.

71. Miyauchi, T., Tomobe, Y., Shiba, R., Ishikawa, T., Yanagisawa, M., Kimura, S., Sugishita, Y., Ito, I., Goto, K. and Masaki, T. (1990). Involvement of endothelin in the regulation of human vascular tonus. Potent vasoconstrictor effect and existence in endothelial cells. Circulation 81 : 1874-1880.

72. Haynes, W.G., Clarke, J.G., Cockcroft, J.R. and Webb, D.J. (1991). Pharmacology of endothelin-1 in vivo in humans. Journal of cardiovascular pharmacology 17 Suppl 7: S284-286.

73. Gasic, S., Wagner, O.F., Vierhapper, H., Nowotny, P. and Waldhausl, W. (1992). Regional hemodynamic effects and clearance of endothelin-1 in humans: renal and peripheral tissues may contribute to the overall disposal of the peptide. Journal of cardiovascular pharmacology 19: $176-180$.

74. Kiowski, W., Sutsch, G., Hunziker, P., Muller, P., Kim, J., Oechslin, E., Schmitt, R., Jones, R. and Bertel, O. (1995). Evidence for endothelin-1-mediated vasoconstriction in severe chronic heart failure. Lancet 346: 732-736.

75. Bohm, F., Johansson, B.L., Hedin, U., Alving, K. and Pernow, J. (2002). Enhanced vasoconstrictor effect of big endothelin-1 in patients with atherosclerosis: relation to conversion to endothelin-1. Atherosclerosis 160: 215-222.

76. Knuckles, T.L., Lund, A.K., Lucas, S.N. and Campen, M.J. (2008). Diesel exhaust exposure enhances venoconstriction via uncoupling of eNOS. Toxicology and applied pharmacology 230 : 346-351.

77. Kodavanti, U.P., Thomas, R.F., Ledbetter, A.D., Schladweiler, M.C., Bass, V., Krantz, Q.T., King, C., Nyska, A., Richards, J.E., Andrews, D. and Gilmour, M.I. (2013). Diesel exhaust induced pulmonary and cardiovascular impairment: the role of hypertension intervention. Toxicology and applied pharmacology 268: 232-240.

78. Nar, G., Soylu, K., Akcay, M., Gulel, O., Yuksel, S., Meric, M., Zengin, H., Erbay, A., Nar, R., Demircan, S. and Sahin, M. (2013). Evaluation of the relationship between arterial blood pressure, aortic stiffness and serum endothelin-1 levels in patients with essential hypertension. Clinical and experimental hypertension (New York, N.Y. : 1993) 35: 589-594.

79. Bohm, F. and Pernow, J. (2007). The importance of endothelin-1 for vascular dysfunction in cardiovascular disease. Cardiovascular research 76: 8-18.

80. Barton, M. (2008). Reversal of proteinuric renal disease and the emerging role of endothelin. Nature clinical practice. Nephrology 4: 490-501.

81. Pernow, J., Shemyakin, A. and Bohm, F. (2012). New perspectives on endothelin-1 in atherosclerosis and diabetes mellitus. Life sciences 91: 507-516.

82. Haynes, W.G. and Webb, D.J. (1994). Contribution of endogenous generation of endothelin-1 to basal vascular tone. Lancet 344: 852-854.

83. Kurihara, Y., Kurihara, H., Suzuki, H., Kodama, T., Maemura, K., Nagai, R., Oda, H., Kuwaki, T., Cao, W.H., Kamada, N. and et al. (1994). Elevated blood pressure and craniofacial abnormalities in mice deficient in endothelin-1. Nature 368: 703-710. 
84. Clouthier, D.E., Hosoda, K., Richardson, J.A., Williams, S.C., Yanagisawa, H., Kuwaki, T., Kumada, M., Hammer, R.E. and Yanagisawa, M. (1998). Cranial and cardiac neural crest defects in endothelin-A receptor-deficient mice. Development (Cambridge, England) 125: 813-824.

85. Clouthier, D.E., Williams, S.C., Yanagisawa, H., Wieduwilt, M., Richardson, J.A. and Yanagisawa, M. (2000). Signaling pathways crucial for craniofacial development revealed by endothelin-A receptor-deficient mice. Developmental biology 217: 10-24.

86. Yanagisawa, H., Hammer, R.E., Richardson, J.A., Williams, S.C., Clouthier, D.E. and Yanagisawa, M. (1998). Role of Endothelin-1/Endothelin-A receptor-mediated signaling pathway in the aortic arch patterning in mice. The Journal of clinical investigation 102: 22-33.

87. Karppinen, S., Rapila, R., Mäkikallio, K., Hänninen, S.L., Rysä, J., Vuolteenaho, O. and Tavi, P. (2014). Endothelin-1 signalling controls early embryonic heart rate in vitro and in vivo. Acta Physiologica 210: 369-380.

88. Dong, F., Zhang, X., Wold, L.E., Ren, Q., Zhang, Z. and Ren, J. (2005). Endothelin-1 enhances oxidative stress, cell proliferation and reduces apoptosis in human umbilical vein endothelial cells: role of ETB receptor, NADPH oxidase and caveolin-1. British journal of pharmacology 145: 323-333.

89. Loomis, E.D., Sullivan, J.C., Osmond, D.A., Pollock, D.M. and Pollock, J.S. (2005). Endothelin mediates superoxide production and vasoconstriction through activation of NADPH oxidase and uncoupled nitric-oxide synthase in the rat aorta. The Journal of pharmacology and experimental therapeutics 315: 1058-1064.

90. Feletou, M. and Vanhoutte, P.M. (2006). Endothelial dysfunction: a multifaceted disorder (The Wiggers Award Lecture). American journal of physiology. Heart and circulatory physiology 291: H985-1002.

91. Duerrschmidt, N., Wippich, N., Goettsch, W., Broemme, H.J. and Morawietz, H. (2000). Endothelin-1 induces NAD(P)H oxidase in human endothelial cells. Biochemical and biophysical research communications 269: 713-717.

92. Ehrenreich, H., Anderson, R.W., Fox, C.H., Rieckmann, P., Hoffman, G.S., Travis, W.D., Coligan, J.E., Kehrl, J.H. and Fauci, A.S. (1990). Endothelins, peptides with potent vasoactive properties, are produced by human macrophages. The Journal of experimental medicine 172: 1741-1748.

93. Fan, J., Unoki, H., Iwasa, S. and Watanabe, T. (2000). Role of endothelin-1 in atherosclerosis. Annals of the New York Academy of Sciences 902: 84-93; discussion 93-84.

94. Gray, G.A., Battistini, B. and Webb, D.J. (2000). Endothelins are potent vasoconstrictors, and much more besides. Trends in pharmacological sciences 21: 38-40.

95. Gossl, M. and Lerman, A. (2006). Endothelin: beyond a vasoconstrictor. Circulation 113: 1156-1158.

96. Ramzy, D., Rao, V., Tumiati, L.C., Xu, N., Sheshgiri, R., Miriuka, S., Delgado, D.H. and Ross, H.J. (2006). Elevated endothelin-1 levels impair nitric oxide homeostasis through a PKCdependent pathway. Circulation 114: I319-326.

97. Barton, M. (2000). Endothelial dysfunction and atherosclerosis: endothelin receptor antagonists as novel therapeutics. Current hypertension reports 2: 84-91.

98. Attinà, T., Camidge, R., Newby, D.E. and Webb, D.J. (2005). Endothelin antagonism in pulmonary hypertension, heart failure, and beyond. Heart 91: 825-831.

99. Battistini, B., Berthiaume, N., Kelland, N.F., Webb, D.J. and Kohan, D.E. (2006). Profile of past and current clinical trials involving endothelin receptor antagonists: the novel "-sentan" class of drug. Experimental biology and medicine (Maywood, N.J.) 231: 653-695.

100. Vita, J.A. (2011). Endothelial function. Circulation 124: e906-912. 
101. Sulli, A., Soldano, S., Pizzorni, C., Montagna, P., Secchi, M.E., Villaggio, B., Seriolo, B., Brizzolara, R. and Cutolo, M. (2009). Raynaud's phenomenon and plasma endothelin:

correlations with capillaroscopic patterns in systemic sclerosis. The Journal of rheumatology 36 : 1235-1239.

102. Evans, R.G., Bergstrom, G., Cotterill, E. and Anderson, W.P. (1998). Renal haemodynamic effects of endothelin-1 and the ETA/ETB antagonist TAK-044 in anaesthetized rabbits. Journal of hypertension 16: 1897-1905.

103. Migneault, A., Sauvageau, S., Villeneuve, L., Thorin, E., Fournier, A., Leblanc, N. and Dupuis, J. (2005). Chronically elevated endothelin levels reduce pulmonary vascular reactivity to nitric oxide. American journal of respiratory and critical care medicine 171: 506-513.

104. Riediker, M., Cascio, W.E., Griggs, T.R., Herbst, M.C., Bromberg, P.A., Neas, L., Williams, R.W. and Devlin, R.B. (2004). Particulate matter exposure in cars is associated with cardiovascular effects in healthy young men. American journal of respiratory and critical care medicine 169: 934-940.

105. Lund, A.K., Knuckles, T.L., Obot Akata, C., Shohet, R., McDonald, J.D., Gigliotti, A., Seagrave, J.C. and Campen, M.J. (2007). Gasoline exhaust emissions induce vascular remodeling pathways involved in atherosclerosis. Toxicological sciences : an official journal of the Society of Toxicology 95: 485-494.

106. Hocher, B., Schwarz, A., Fagan, K.A., Thone-Reineke, C., El-Hag, K., Kusserow, H., Elitok, S., Bauer, C., Neumayer, H.H., Rodman, D.M. and Theuring, F. (2000). Pulmonary fibrosis and chronic lung inflammation in ET-1 transgenic mice. American journal of respiratory cell and molecular biology 23: 19-26.

107. Channick, R.N., Simonneau, G., Sitbon, O., Robbins, I.M., Frost, A., Tapson, V.F., Badesch, D.B., Roux, S., Rainisio, M., Bodin, F. and Rubin, L.J. (2001). Effects of the dual endothelinreceptor antagonist bosentan in patients with pulmonary hypertension: a randomised placebocontrolled study. The Lancet 358: 1119-1123.

108. Leuchte, H.H., Meis, T., El-Nounou, M., Michalek, J. and Behr, J. (2008). Inhalation of endothelin receptor blockers in pulmonary hypertension. American journal of physiology. Lung cellular and molecular physiology 294: L772-777.

109. Calderon-Garciduenas, L., Vincent, R., Mora-Tiscareno, A., Franco-Lira, M., HenriquezRoldan, C., Barragan-Mejia, G., Garrido-Garcia, L., Camacho-Reyes, L., Valencia-Salazar, G., Paredes, R., Romero, L., Osnaya, H., Villarreal-Calderon, R., Torres-Jardon, R., Hazucha, M.J. and Reed, W. (2007). Elevated plasma endothelin-1 and pulmonary arterial pressure in children exposed to air pollution. Environmental health perspectives 115: 1248-1253.

110. Ambient (Outdoor) Air Pollution in Cities Database 2014. 2014. Available from: www.who.int. Accessed June 15, 2015.

111. Calderon-Garciduenas, L., Villarreal-Calderon, R., Valencia-Salazar, G., HenriquezRoldan, C., Gutierrez-Castrellon, P., Torres-Jardon, R., Osnaya-Brizuela, N., Romero, L., TorresJardon, R., Solt, A. and Reed, W. (2008). Systemic inflammation, endothelial dysfunction, and activation in clinically healthy children exposed to air pollutants. Inhalation toxicology 20: 499506.

112. Lund, A.K., Lucero, J., Lucas, S., Madden, M.C., McDonald, J.D., Seagrave, J.C., Knuckles, T.L. and Campen, M.J. (2009). Vehicular emissions induce vascular MMP-9 expression and activity associated with endothelin-1-mediated pathways. Arteriosclerosis, thrombosis, and vascular biology 29: 511-517.

113. Peretz, A., Sullivan, J.H., Leotta, D.F., Trenga, C.A., Sands, F.N., Allen, J., Carlsten, C., Wilkinson, C.W., Gill, E.A. and Kaufman, J.D. (2008). Diesel exhaust inhalation elicits acute vasoconstriction in vivo. Environmental health perspectives 116: 937-942. 
114. Brook, R.D. (2002). Inhalation of Fine Particulate Air Pollution and Ozone Causes Acute Arterial Vasoconstriction in Healthy Adults. Circulation 105: 1534-1536.

115. Mills, N.L., Tornqvist, H., Robinson, S.D., Gonzalez, M., Darnley, K., MacNee, W., Boon, N.A., Donaldson, K., Blomberg, A., Sandstrom, T. and Newby, D.E. (2005). Diesel exhaust inhalation causes vascular dysfunction and impaired endogenous fibrinolysis. Circulation 112: 3930-3936.

116. Langrish, J.P., Lundback, M., Mills, N.L., Johnston, N.R., Webb, D.J., Sandstrom, T., Blomberg, A. and Newby, D.E. (2009). Contribution of endothelin 1 to the vascular effects of diesel exhaust inhalation in humans. Hypertension 54: 910-915.

117. Verhaar, M.C., Strachan, F.E., Newby, D.E., Cruden, N.L., Koomans, H.A., Rabelink, T.J. and Webb, D.J. (1998). Endothelin-A receptor antagonist-mediated vasodilatation is attenuated by inhibition of nitric oxide synthesis and by endothelin-B receptor blockade. Circulation 97: 752-756.

118. Bigert, C., Gustavsson, P., Hallqvist, J., Hogstedt, C., Lewne, M., Plato, N., Reuterwall, C. and Scheele, P. (2003). Myocardial infarction among professional drivers. Epidemiology 14: 333339.

119. Barbosa, C.M., Terra-Filho, M., de Albuquerque, A.L., Di Giorgi, D., Grupi, C., Negrao, C.E., Rondon, M.U., Martinez, D.G., Marcourakis, T., dos Santos, F.A., Braga, A.L., Zanetta, D.M. and Santos Ude, P. (2012). Burnt sugarcane harvesting - cardiovascular effects on a group of healthy workers, Brazil. PloS one 7: e46142.

120. Fang, S.C., Cavallari, J.M., Eisen, E.A., Chen, J.C., Mittleman, M.A. and Christiani, D.C. (2009). Vascular function, inflammation, and variations in cardiac autonomic responses to particulate matter among welders. American journal of epidemiology 169: 848-856.

121. Jarvela, M., Kauppi, P., Tuomi, T., Luukkonen, R., Lindholm, H., Nieminen, R., Moilanen, E. and Hannu, T. (2013). Inflammatory response to acute exposure to welding fumes during the working day. International journal of occupational medicine and environmental health 26: 220229.

122. Scharrer, E., Hessel, H., Kronseder, A., Guth, W., Rolinski, B., Jorres, R.A., Radon, K., Schierl, R., Angerer, P. and Nowak, D. (2007). Heart rate variability, hemostatic and acute inflammatory blood parameters in healthy adults after short-term exposure to welding fume. International archives of occupational and environmental health 80: 265-272.

123. Campen, M.J., Lund, A.K., Doyle-Eisele, M.L., McDonald, J.D., Knuckles, T.L., Rohr, A.C., Knipping, E.M. and Mauderly, J.L. (2010). A comparison of vascular effects from complex and individual air pollutants indicates a role for monoxide gases and volatile hydrocarbons. Environmental health perspectives 118: 921-927.

124. Campen, M.J., Babu, N.S., Helms, G.A., Pett, S., Wernly, J., Mehran, R. and McDonald, J.D. (2005). Nonparticulate components of diesel exhaust promote constriction in coronary arteries from ApoE-/- mice. Toxicological sciences : an official journal of the Society of Toxicology 88: 95-102.

125. Cherng, T.W., Campen, M.J., Knuckles, T.L., Gonzalez Bosc, L. and Kanagy, N.L. (2009). Impairment of coronary endothelial cell ET(B) receptor function after short-term inhalation exposure to whole diesel emissions. American Journal of Physiology - Regulatory, Integrative and Comparative Physiology 297: R640-R647.

126. Kodavanti, U.P., Thomas, R., Ledbetter, A.D., Schladweiler, M.C., Shannahan, J.H., Wallenborn, J.G., Lund, A.K., Campen, M.J., Butler, E.O., Gottipolu, R.R., Nyska, A., Richards, J.E., Andrews, D., Jaskot, R.H., McKee, J., Kotha, S.R., Patel, R.B. and Parinandi, N.L. (2011). Vascular and cardiac impairments in rats inhaling ozone and diesel exhaust particles. Environmental health perspectives 119: 312-318. 
127. Ito, T., Suzuki, T., Tamura, K., Nezu, T., Honda, K. and Kobayashi, T. (2008). Examination of mRNA expression in rat hearts and lungs for analysis of effects of exposure to concentrated ambient particles on cardiovascular function. Toxicology 243: 271-283.

128. Bouthillier, L., Vincent, R., Goegan, P., Adamson, I.Y.R., Bjarnason, S., Stewart, M., Guénette, J., Potvin, M. and Kumarathasan, P. (1998). Acute Effects of Inhaled Urban Particles and Ozone. The American Journal of Pathology 153: 1873-1884.

129. Miyata, R., Hiraiwa, K., Cheng, J.C., Bai, N., Vincent, R., Francis, G.A., Sin, D.D. and Van Eeden, S.F. (2013). Statins attenuate the development of atherosclerosis and endothelial dysfunction induced by exposure to urban particulate matter (PM10). Toxicology and applied pharmacology 272: 1-11.

130. Paczkowska, E., Gołąb-Janowska, M., Bajer-Czajkowska, A., Machalińska, A., Ustianowski, P., Rybicka, M., Kłos, P., Dziedziejko, V., Safranow, K., Nowacki, P. and Machaliński, B. (2013). Increased circulating endothelial progenitor cells in patients with haemorrhagic and ischaemic stroke: The role of Endothelin-1. Journal of the Neurological Sciences 325: 90-99.

131. O'Toole, T.E., Hellmann, J., Wheat, L., Haberzettl, P., Lee, J., Conklin, D.J., Bhatnagar, A. and Pope, C.A., 3rd. (2010). Episodic exposure to fine particulate air pollution decreases circulating levels of endothelial progenitor cells. Circulation research 107: 200-203.

132. Haberzettl, P., Lee, J., Duggineni, D., McCracken, J., Bolanowski, D., O'Toole, T.E., Bhatnagar, A. and Conklin, D.J. (2012). Exposure to Ambient Air Fine Particulate Matter Prevents VEGF-Induced Mobilization of Endothelial Progenitor Cells from the Bone Marrow.

Environmental health perspectives 120: 848-856.

133. Wheat, L.A., Haberzettl, P., Hellmann, J., Baba, S.P., Bertke, M., Lee, J., McCracken, J., O'Toole, T.E., Bhatnagar, A. and Conklin, D.J. (2011). Acrolein Inhalation Prevents Vascular Endothelial Growth Factor-Induced Mobilization of Flk-1+/Sca-1+Cells in Mice. Arteriosclerosis, thrombosis, and vascular biology 31: 1598-1606.

134. Matsuura, A., Yamochi, W., Hirata, K.-i., Kawashima, S. and Yokoyama, M. (1998).

Stimulatory Interaction Between Vascular Endothelial Growth Factor and Endothelin-1 on Each Gene Expression. Hypertension 32: 89-95.

135. Grant, K., Loizidou, M. and Taylor, I. (2003). Endothelin-1: a multifunctional molecule in cancer. British Journal of Cancer 88: 163-166.

136. Lankhorst, S., Kappers, M.H.W., van Esch, J.H.M., Danser, A.H.J. and van den Meiracker, A.H. (2014). Hypertension During Vascular Endothelial Growth Factor Inhibition: Focus on Nitric Oxide, Endothelin-1, and Oxidative Stress. Antioxidants \& Redox Signaling 20: 135-145.

137. Star, G.P., Giovinazzo, M., Lamoureux, E. and Langleben, D. (2014). Effects of vascular endothelial growth factor on endothelin-1 production by human lung microvascular endothelial cells in vitro. Life sciences 118: 191-194.

138. Jung, C., Rafnsson, A., Brismar, K. and Pernow, J. (2013). Endothelial progenitor cells in relation to endothelin-1 and endothelin receptor blockade: a randomized, controlled trial. International journal of cardiology 168: 1017-1022.

139. Wu, M.H., Huang, C.Y., Lin, J.A., Wang, S.W., Peng, C.Y., Cheng, H.C. and Tang, C.H. (2014). Endothelin-1 promotes vascular endothelial growth factor-dependent angiogenesis in human chondrosarcoma cells. Oncogene 33: 1725-1735.

140. Kähler, J., Mendel, S., Weckmüller, J., Orzechowski, H.-D., Mittmann, C., Köster, R., Paul, M., Meinertz, T. and Münzel, T. (2000). Oxidative Stress Increases Synthesis of Big Endothelin-1 by Activation of the Endothelin-1 Promoter. Journal of Molecular and Cellular Cardiology 32: 1429-1437. 
141. Kahler, J., Ewert, A., Weckmuller, J., Stobbe, S., Mittmann, C., Koster, R., Paul, M., Meinertz, T. and Munzel, T. (2001). Oxidative stress increases endothelin-1 synthesis in human coronary artery smooth muscle cells. Journal of cardiovascular pharmacology 38: 49-57.

142. Ruef, J., Moser, M., Kubler, W. and Bode, C. (2001). Induction of endothelin-1 expression by oxidative stress in vascular smooth muscle cells. Cardiovascular pathology : the official journal of the Society for Cardiovascular Pathology 10: 311-315.

143. Hughes, A.K., Stricklett, P.K., Padilla, E. and Kohan, D.E. (1996). Effect of reactive oxygen species on endothelin-1 production by human mesangial cells. Kidney international 49: 181-189. 144. Chen, H.C., Guh, J.Y., Shin, S.J., Tsai, J.H. and Lai, Y.H. (2000). Reactive oxygen species enhances endothelin-1 production of diabetic rat glomeruli in vitro and in vivo. The Journal of laboratory and clinical medicine 135: 309-315.

145. Mates, J.M., Perez-Gomez, C. and Nunez de Castro, I. (1999). Antioxidant enzymes and human diseases. Clinical biochemistry 32: 595-603.

146. Jung, O., Marklund, S.L., Geiger, H., Pedrazzini, T., Busse, R. and Brandes, R.P. (2003). Extracellular superoxide dismutase is a major determinant of nitric oxide bioavailability: in vivo and ex vivo evidence from ecSOD-deficient mice. Circulation research 93: 622-629.

147. Break, T.J., Jun, S., Indramohan, M., Carr, K.D., Sieve, A.N., Dory, L. and Berg, R.E. (2012). Extracellular superoxide dismutase inhibits innate immune responses and clearance of an intracellular bacterial infection. Journal of immunology (Baltimore, Md. : 1950) 188: 3342-3350. 148. Yao, H., Arunachalam, G., Hwang, J.-w., Chung, S., Sundar, I.K., Kinnula, V.L., Crapo, J.D. and Rahman, I. (2010). Extracellular superoxide dismutase protects against pulmonary emphysema by attenuating oxidative fragmentation of ECM. Proceedings of the National Academy of Sciences of the United States of America 107: 15571-15576.

149. Haberzettl, P., O'Toole, T.E., Bhatnagar, A. and Conklin, D.J. (2016). Exposure to Fine Particulate Air Pollution Causes Vascular Insulin Resistance by Inducing Pulmonary Oxidative Stress. Environmental health perspectives.

150. US Environmental Protection Agency. (1997). Revised requirements for designation of reference and equivalent methods for PM2.5 and ambient air quality surveillance for particulate matter, Final Rule, (Agency, U.E.P., ed), Federal Register.

151. Pope, C.A., 3rd, Muhlestein, J.B., May, H.T., Renlund, D.G., Anderson, J.L. and Horne, B.D. (2006). Ischemic heart disease events triggered by short-term exposure to fine particulate air pollution. Circulation 114: 2443-2448.

152. Duda, D.G., Cohen, K.S., Scadden, D.T. and Jain, R.K. (2007). A protocol for phenotypic detection and enumeration of circulating endothelial cells and circulating progenitor cells in human blood. Nature protocols 2: 805-810.

153. Maciejczyk, P., Zhong, M., Li, Q., Xiong, J., Nadziejko, C. and Chen, L.C. (2005). Effects of subchronic exposures to concentrated ambient particles (CAPs) in mice. II. The design of a CAPs exposure system for biometric telemetry monitoring. Inhalation toxicology 17: 189-197.

154. Kruse, H.-J., Wieczorek, I., Hecker, H., Creutzig, A. and Schellong, S.M. (2002). Seasonal variation of endothelin-1, angiotensin II, and plasma catecholamines and their relation to outside temperature. Journal of Laboratory and Clinical Medicine 140: 236-241.

155. Prineas, R.J., Gillum, R.F., Horibe, H. and Hannan, P.J. (1980). The Minneapolis children's blood pressure study. Part 1: standards of measurement for children's blood pressure. Hypertension 2: I18-24.

156. Argilés, À., Mourad, G. and Mion, C. (1998). Seasonal Changes in Blood Pressure in Patients with End-Stage Renal Disease Treated with Hemodialysis. New England Journal of Medicine 339: 1364-1370. 
157. de Swiet, M., Fayers, P.M. and Shinebourne, E.A. (1984). Blood pressure in four and fiveyear-old children: the effects of environment and other factors in it's measurement--the Brompton study. Journal of hypertension 2: 501-505.

158. Jenner, D.A., English, D.R., Vandongen, R., Beilin, L.J., Armstrong, B.K. and Dunbar, D. (1987). Environmental temperature and blood pressure in 9-year-old Australian children. Journal of hypertension 5: 683-686.

159. Freeman, B.D., Machado, F.S., Tanowitz, H.B. and Desruisseaux, M.S. (2014). Endothelin1 and its role in the pathogenesis of infectious diseases. Life sciences 118: 110-119.

160. Kowalczyk, A., Kleniewska, P., Kolodziejczyk, M., Skibska, B. and Goraca, A. (2015). The Role of Endothelin-1 and Endothelin Receptor Antagonists in Inflammatory Response and Sepsis. Archivum Immunologiae et Therapiae Experimentalis 63: 41-52.

161. Ridker, P.M. and Group, o.b.o.t.J.S. (2003). Rosuvastatin in the Primary Prevention of Cardiovascular Disease Among Patients With Low Levels of Low-Density Lipoprotein Cholesterol and Elevated High-Sensitivity C-Reactive Protein: Rationale and Design of the JUPITER Trial. Circulation 108: 2292-2297.

162. Yeh, E.T.H. and Willerson, J.T. (2003). Coming of Age of C-Reactive Protein: Using Inflammation Markers in Cardiology. Circulation 107: 370-371.

163. Oh, J., Teoh, H. and Leiter, L.A. (2011). Should C-Reactive Protein Be a Target of Therapy? Diabetes care 34: S155-S160.

164. Javadzadeh, A., Ghorbanihaghjo, A., Adl, F.H., Andalib, D., Khojasteh-Jafari, H. and Ghabili, K. (2013). Calcium dobesilate reduces endothelin-1 and high-sensitivity C-reactive protein serum levels in patients with diabetic retinopathy. Molecular vision 19: 62-68.

165. Diehl, K.J., Weil, B.R., Greiner, J.J., Stauffer, B.L. and DeSouza, C.A. (2012). White blood cell count and endothelin-1 vasoconstrictor tone in middle-aged and older adults. Artery research 6: 65-70.

166. Flammer, A.J., Anderson, T., Celermajer, D.S., Creager, M.A., Deanfield, J., Ganz, P., Hamburg, N.M., Luscher, T.F., Shechter, M., Taddei, S., Vita, J.A. and Lerman, A. (2012). The assessment of endothelial function: from research into clinical practice. Circulation 126: 753767.

167. Kullo, I.J., Hensrud, D.D. and Allison, T.G. (2002). Comparison of numbers of circulating blood monocytes in men grouped by body mass index $(<25,25$ to $<30,>$ or $=30)$. The American journal of cardiology 89: 1441-1443.

168. Veronelli, A., Laneri, M., Ranieri, R., Koprivec, D., Vardaro, D., Paganelli, M., Folli, F. and Pontiroli, A.E. (2004). White Blood Cells in Obesity and Diabetes: Effects of weight loss and normalization of glucose metabolism. Diabetes care 27: 2501-2502.

169. Loscalzo, J. (2001). Nitric oxide insufficiency, platelet activation, and arterial thrombosis. Circulation research 88: 756-762.

170. Deanfield, J.E., Halcox, J.P. and Rabelink, T.J. (2007). Endothelial Function and Dysfunction: Testing and Clinical Relevance. Circulation 115: 1285-1295.

171. Jansson, P.A. (2007). Endothelial dysfunction in insulin resistance and type 2 diabetes. Journal of internal medicine 262: 173-183.

172. Smith, A.P., Demoncheaux, E.A. and Higenbottam, T.W. (2002). Nitric oxide gas decreases endothelin-1 mRNA in cultured pulmonary artery endothelial cells. Nitric oxide : biology and chemistry / official journal of the Nitric Oxide Society 6: 153-159.

173. Weng, Y.H., Kuo, C.Y., Chiu, Y.W., Kuo, M.L. and Liao, S.L. (2009). Alteration of nitric oxide gas on gene expression of endothelin-1 and endothelial nitric oxide synthase by a timeand dose-dependent manner in human endothelial cells. The Chinese journal of physiology 52: 59-64. 
174. Wagner, F.D., Buz, S., Knosalla, C., Hetzer, R. and Hocher, B. (2003). Modulation of Circulating Endothelin-1 and Big Endothelin by Nitric Oxide Inhalation Following Left Ventricular Assist Device Implantation. Circulation 108: II-278-II-284.

175. Li, Z., Carter, J.D., Dailey, L.A. and Huang, Y.C. (2005). Pollutant particles produce vasoconstriction and enhance MAPK signaling via angiotensin type I receptor. Environmental health perspectives 113: 1009-1014.

176. Jacobs, L., Buczynska, A., Walgraeve, C., Delcloo, A., Potgieter-Vermaak, S., Van Grieken, R., Demeestere, K., Dewulf, J., Van Langenhove, H., De Backer, H., Nemery, B. and Nawrot, T.S. (2012). Acute changes in pulse pressure in relation to constituents of particulate air pollution in elderly persons. Environmental research 117: 60-67.

177. Shi, S.J., Preuss, H.G., Abernethy, D.R., Li, X., Jarrell, S.T. and Andrawis, N.S. (1997). Elevated blood pressure in spontaneously hypertensive rats consuming a high sucrose diet is associated with elevated angiotensin II and is reversed by vanadium. Journal of hypertension 15 : 857-862.

178. Huang, Y.C. and Ghio, A.J. (2006). Vascular effects of ambient pollutant particles and metals. Current vascular pharmacology 4: 199-203.

179. Hill, J.M., Zalos, G., Halcox, J.P.J., Schenke, W.H., Waclawiw, M.A., Quyyumi, A.A. and Finkel, T. (2003). Circulating Endothelial Progenitor Cells, Vascular Function, and Cardiovascular Risk. New England Journal of Medicine 348: 593-600.

180. Fadini, G.P., Losordo, D. and Dimmeler, S. (2012). Critical re-evaluation of endothelial progenitor cell phenotypes for therapeutic and diagnostic use. Circulation research 110: 624637.

181. Freixa, X., Masotti, M., Palomo, M., Diaz-Ricart, M., Escolar, G., Guasch, E., Regueiro, A., Jiménez, M., Betriu, A. and Heras, M. (2011). Endothelin-1 levels predict endothelial progenitor cell mobilization after acute myocardial infarction. Microvascular Research 82: 177-181.

182. Brook, R.D. and Rajagopalan, S. (2012). Chronic Air Pollution Exposure and Endothelial DysfunctionWhat You Can't See-Can Harm You**. Journal of the American College of Cardiology 60: 2167-2169.

183. Bigazzi, A.Y., Figliozzi, M.A. and Clifton, K.J. (2015). Traffic Congestion and Air Pollution Exposure for Motorists: Comparing Exposure Duration and Intensity. International Journal of Sustainable Transportation 9: 443-456.

184. Chen, H., Goldberg, M.S. and Villeneuve, P.J. (2008). A systematic review of the relation between long-term exposure to ambient air pollution and chronic diseases. Reviews on environmental health 23: 243-297.

185. Pénard-Morand, C., Raherison, C., Charpin, D., Kopferschmitt, C., Lavaud, F., Caillaud, D. and Annesi-Maesano, I. (2010). Long-term exposure to close-proximity air pollution and asthma and allergies in urban children. European Respiratory Journal 36: 33-40.

186. Gongora, M.C., Qin, Z., Laude, K., Kim, H.W., McCann, L., Folz, J.R., Dikalov, S., Fukai, T. and Harrison, D.G. (2006). Role of extracellular superoxide dismutase in hypertension. Hypertension 48: 473-481.

187. Qin, Z., Reszka, K.J., Fukai, T. and Weintraub, N.L. (2008). Extracellular superoxide dismutase (ecSOD) in vascular biology: an update on exogenous gene transfer and endogenous regulators of ecSOD. Translational research : the journal of laboratory and clinical medicine 151: 68-78.

188. Obal, D., Dai, S., Keith, R., Dimova, N., Kingery, J., Zheng, Y.-T., Zweier, J., Velayutham, M., Prabhu, S.D., Li, Q., Conklin, D., Yang, D., Bhatnagar, A., Bolli, R. and Rokosh, G. (2012). Cardiomyocyte-restricted overexpression of extracellular superoxide dismutase increases nitric 
oxide bioavailability and reduces infarct size after ischemia/reperfusion. Basic research in cardiology 107: 305.

189. Rahal, A., Kumar, A., Singh, V., Yadav, B., Tiwari, R., Chakraborty, S. and Dhama, K. (2014). Oxidative Stress, Prooxidants, and Antioxidants: The Interplay. BioMed Research International 2014: 19.

190. Jun, S., Fattman, C.L., Kim, B.J., Jones, H. and Dory, L. (2011). Allele-specific effects of ecSOD on asbestos-induced fibroproliferative lung disease in mice. Free Radic Biol Med 50: 1288-1296.

191. Owens, G.K., Kumar, M.S. and Wamhoff, B.R. (2004). Molecular Regulation of Vascular Smooth Muscle Cell Differentiation in Development and Disease. Physiological Reviews 84: 767801.

192. Gomez, D. and Owens, G.K. (2012). Smooth muscle cell phenotypic switching in atherosclerosis. Cardiovascular research 95: 156-164.

193. Guo, D.-C., Pannu, H., Tran-Fadulu, V., Papke, C.L., Yu, R.K., Avidan, N., Bourgeois, S., Estrera, A.L., Safi, H.J., Sparks, E., Amor, D., Ades, L., McConnell, V., Willoughby, C.E., Abuelo, D., Willing, M., Lewis, R.A., Kim, D.H., Scherer, S., Tung, P.P., Ahn, C., Buja, L.M., Raman, C.S., Shete, S.S. and Milewicz, D.M. (2007). Mutations in smooth muscle [alpha]-actin (ACTA2) lead to thoracic aortic aneurysms and dissections. Nat Genet 39: 1488-1493.

194. Arnoldi, R., Hiltbrunner, A., Dugina, V., Tille, J.-C. and Chaponnier, C. (2013). Smooth muscle actin isoforms: A tug of war between contraction and compliance. European Journal of Cell Biology 92: 187-200.

195. Sehgel, N.L., Zhu, Y., Sun, Z., Trzeciakowski, J.P., Hong, Z., Hunter, W.C., Vatner, D.E., Meininger, G.A. and Vatner, S.F. (2013). Increased vascular smooth muscle cell stiffness: a novel mechanism for aortic stiffness in hypertension. American Journal of Physiology - Heart and Circulatory Physiology 305: H1281-H1287.

196. Bentley, J.K. and Hershenson, M.B. (2008). Airway Smooth Muscle Growth in Asthma: Proliferation, Hypertrophy, and Migration. Proceedings of the American Thoracic Society 5: 8996.

197. Berair, R., Hollins, F. and Brightling, C. (2013). Airway Smooth Muscle Hypercontractility in Asthma. Journal of Allergy 2013: 7.

198. Sobue, K., Hayashi, K.i. and Nishida, W. (1999). Expressional regulation of smooth muscle cell-specific genes in association with phenotypic modulation, in Muscle Physiology and Biochemistry (Imai, S., Ohtsuki, I. and Endo, M., eds), pp105-118, Springer US, Boston, MA. 199. Rzucidlo, E.M., Martin, K.A. and Powell, R.J. (2007). Regulation of vascular smooth muscle cell differentiation. Journal of Vascular Surgery 45: A25-A32.

200. Lee, J.H., Reed, D.R. and Price, R.A. (2001). Leptin resistance is associated with extreme obesity and aggregates in families. International journal of obesity and related metabolic disorders : journal of the International Association for the Study of Obesity 25: 1471-1473. 201. Myers, M.G., Leibel, R.L., Seeley, R.J. and Schwartz, M.W. (2010). Obesity and Leptin Resistance: Distinguishing Cause from Effect. Trends in endocrinology and metabolism: TEM 21: 643-651.

202. Yang, B., Li, M., Chen, B., Xu, Y. and Li, T.D. (2012). Deterioration of endothelial function and carotid intima-media thickness in Tibetan male adolescents exposed to second-hand smoke. Journal of the renin-angiotensin-aldosterone system : JRAAS 13: 413-419.

203. Münzberg, H. and Heymsfield, S.B. (2015). Leptin, Obesity, and Leptin Resistance, in Leptin: Regulation and Clinical Applications (Dagogo-Jack, M.D.S., ed), pp67-78, Springer International Publishing, Cham. 
204. Sáinz, N., Barrenetxe, J., Moreno-Aliaga, M.J. and Martínez, J.A. (2015). Leptin resistance and diet-induced obesity: central and peripheral actions of leptin. Metabolism 64: 35-46.

205. Ferri, C., Bellini, C., Desideri, G., Di Francesco, L., Baldoncini, R., Santucci, A. and De Mattia, G. (1995). Plasma Endothelin-1 Levels in Obese Hypertensive and Normotensive Men. Diabetes 44: 431-436.

206. Campia, U., Tesauro, M., Di Daniele, N. and Cardillo, C. (2014). The vascular endothelin system in obesity and type 2 diabetes: Pathophysiology and therapeutic implications. Life sciences 118: 149-155.

207. Weil, B.R., Westby, C.M., Van Guilder, G.P., Greiner, J.J., Stauffer, B.L. and DeSouza, C.A. (2011). Enhanced endothelin-1 system activity with overweight and obesity. American Journal of Physiology - Heart and Circulatory Physiology 301: H689-H695.

208. Cardillo, C., Campia, U., lantorno, M. and Panza, J.A. (2004). Enhanced vascular activity of endogenous endothelin-1 in obese hypertensive patients. Hypertension 43: 36-40.

209. Timperio, A., Salmon, J., Telford, A. and Crawford, D. (2005). Perceptions of local neighbourhood environments and their relationship to childhood overweight and obesity. International journal of obesity (2005) 29: 170-175.

210. Jerrett, M., McConnell, R., Chang, C.C., Wolch, J., Reynolds, K., Lurmann, F., Gilliland, F. and Berhane, K. (2010). Automobile traffic around the home and attained body mass index: a longitudinal cohort study of children aged 10-18 years. Preventive medicine 50 Suppl 1: S50-58. 211. McConnell, R., Shen, E., Gilliland, F.D., Jerrett, M., Wolch, J., Chang, C.C., Lurmann, F. and Berhane, K. (2015). A longitudinal cohort study of body mass index and childhood exposure to secondhand tobacco smoke and air pollution: the Southern California Children's Health Study. Environmental health perspectives 123: 360-366.

212. Quehenberger, P., Exner, M., Sunder-Plassmann, R., Ruzicka, K., Bieglmayer, C., Endler, G., Muellner, C., Speiser, W. and Wagner, O. (2002). Leptin induces endothelin-1 in endothelial cells in vitro. Circulation research 90: 711-718.

213. Xu, F.-P., Chen, M.-S., Wang, Y.-Z., Yi, Q., Lin, S.-B., Chen, A.F. and Luo, J.-D. (2004). Leptin Induces Hypertrophy via Endothelin-1-Reactive Oxygen Species Pathway in Cultured Neonatal Rat Cardiomyocytes. Circulation 110: 1269-1275.

214. Schinzari, F., Tesauro, M., Rovella, V., Di Daniele, N., Mores, N., Veneziani, A. and Cardillo, C. (2013). Leptin stimulates both endothelin-1 and nitric oxide activity in lean subjects but not in patients with obesity-related metabolic syndrome. The Journal of clinical endocrinology and metabolism 98: 1235-1241.

215. Eckel, R.H. and Committee, F.t.N. (1997). Obesity and Heart Disease: A Statement for Healthcare Professionals From the Nutrition Committee, American Heart Association. Circulation 96: 3248-3250.

216. Brietta, F., Sonia, M.C., Timothy, W., Leslie, S. and Lewis, S. (2015). Characterization of Patients with Obesity and Pulmonary Hypertension, in C58. CLINICAL PULMONARY VASCULAR DISEASE, ppA4815-A4815, American Thoracic Society.

217. Dawber, T.R., Moore, F.E. and Mann, G.V. (2015). II. Coronary Heart Disease in the Framingham Study. International Journal of Epidemiology 44: 1767-1780.

218. Lu, K.D., Manoukian, K., Radom-Aizik, S., Cooper, D.M. and Galant, S.P. (2015). Obesity, Asthma, and Exercise in Child and Adolescent Health. Pediatric exercise science.

219. Schatz, M., Zeiger, R.S., Yang, S.-J., Chen, W., Sajjan, S., Allen-Ramey, F. and Camargo Jr, C.A. (2015). Prospective Study on the Relationship of Obesity to Asthma Impairment and Risk. The Journal of Allergy and Clinical Immunology: In Practice 3: 560-565.e561.

220. Mozaffarian, D., Benjamin, E.J., Go, A.S., Arnett, D.K., Blaha, M.J., Cushman, M., Das, S.R., de Ferranti, S., Després, J.-P., Fullerton, H.J., Howard, V.J., Huffman, M.D., Isasi, C.R., 
Jiménez, M.C., Judd, S.E., Kissela, B.M., Lichtman, J.H., Lisabeth, L.D., Liu, S., Mackey, R.H., Magid, D.J., McGuire, D.K., Mohler, E.R., Moy, C.S., Muntner, P., Mussolino, M.E., Nasir, K., Neumar, R.W., Nichol, G., Palaniappan, L., Pandey, D.K., Reeves, M.J., Rodriguez, C.J., Rosamond, W., Sorlie, P.D., Stein, J., Towfighi, A., Turan, T.N., Virani, S.S., Woo, D., Yeh, R.W. and Turner, M.B. (2016). Executive Summary: Heart Disease and Stroke Statistics-2016 Update: A Report From the American Heart Association. Circulation 133: 447-454.

221. Mosca, L., Mochari-Greenberger, H., Dolor, R.J., Newby, L.K. and Robb, K.J. (2010). Twelve-Year Follow-Up of American Women's Awareness of Cardiovascular Disease Risk and Barriers to Heart Health. Circulation: Cardiovascular Quality and Outcomes 3: 120-127.

222. Pugh, M.E. and Hemnes, A.R. (2010). Pulmonary hypertension in women. Expert review of cardiovascular therapy 8: 1549-1558.

223. Grunig, G., Marsh, L.M., Esmaeil, N., Jackson, K., Gordon, T., Reibman, J., Kwapiszewska, G. and Park, S.-H. (2014). Perspective: ambient air pollution: inflammatory response and effects on the lung's vasculature. Pulmonary Circulation 4: 25-35.

224. Park, S.-H., Chen, W.-C., Esmaeil, N., Lucas, B., Marsh, L.M., Reibman, J. and Grunig, G. (2014). Interleukin 13- and interleukin 17A-induced pulmonary hypertension phenotype due to inhalation of antigen and fine particles from air pollution. Pulmonary Circulation 4: 654-668. 


\title{
APPENDICES
}

\author{
ABBREVIATIONS \\ Akt Protein kinase B \\ $\mathrm{Ca}^{2+} \quad$ Calcium \\ CAP Concentrated ambient air particulate matter \\ CDC Centers for Disease Control and Prevention \\ CIMT Carotid intima media thickness \\ cGMP Cyclic guanosine monophosphate \\ COPD Chronic obstructive pulmonary disease \\ CT Threshold cycle \\ CVD Cardiovascular disease \\ DE Diesel exhaust \\ EC Endothelial cell \\ ECE Endothelin-converting enzyme \\ ECM Extracellular matrix
}




\begin{tabular}{|c|c|}
\hline ecSOD & Extracellular superoxide dismutase \\
\hline ecSOD-Tg & Extracellular superoxide dismutase-transgenic \\
\hline eNOS & Endothelial nitric oxide synthase \\
\hline EPC & Endothelial progenitor cell \\
\hline ERK & Extracellular signal-regulated kinases \\
\hline ET-1 & Endothelin-1 \\
\hline ET-2 & Endothelin-2 \\
\hline ET-3 & Endothelin-3 \\
\hline $\mathrm{ET}_{\mathrm{A}}$ & Endothelin receptor A \\
\hline $\mathrm{ET}_{\mathrm{B}}$ & Endothelin receptor B \\
\hline $\mathrm{ET}_{\mathrm{B} 1}$ & Endothelin receptor B1 \\
\hline $\mathrm{ET}_{\mathrm{B} 2}$ & Endothelin receptor B2 \\
\hline FMD & Flow-mediated dilation \\
\hline GEE & Gasoline engine exhaust \\
\hline HEPA & High-efficiency particulate air \\
\hline HRV & Heart rate variability \\
\hline hsCRP & C-reactive protein \\
\hline
\end{tabular}




\begin{tabular}{|c|c|}
\hline HTN & Hypertension \\
\hline HUVEC & Human umbilical vein endothelial cells \\
\hline $\mathrm{IL}$ & Interleukin \\
\hline InR & Insulin receptor \\
\hline MI & Myocardial infarction \\
\hline MMP & Matrix metalloproteinase \\
\hline mRPP0 & Mouse ribosomal protein $\mathrm{P} 0$ \\
\hline NO & Nitric oxide \\
\hline $\mathrm{O}_{3}$ & Ozone \\
\hline OS & Oxidative stress \\
\hline $\mathrm{PKC}$ & Protein kinase $\mathrm{C}$ \\
\hline PKG & Protein kinase $\mathrm{G}$ \\
\hline PM & Particulate matter \\
\hline PVAT & Perivascular adipose tissue \\
\hline qRT-PCR & Real-time quantitative PCR \\
\hline ROS & Reactive oxygen species \\
\hline RO & Relative expression \\
\hline
\end{tabular}




\begin{tabular}{ll} 
SGC & Soluble guanylyl cyclase \\
SOD & Superoxide dismutase \\
SMA & Smooth muscle actin \\
TEOM & Tapered element oscillating microbalance \\
TGF $\beta$ & Transforming growth factor-beta \\
TNF $\alpha$ & Tumor necrosis factor- $\alpha$ \\
VEGF & Vascular endothelial growth factor \\
VR & VEGF receptor \\
VSMC & Vascular smooth muscle cell \\
WHO & World Health Organization \\
\hline
\end{tabular}




\section{COPYRIGHT CLEARANCE}

This Agreement between Jordan Finch ("You") and Springer ("Springer") consists of your license details and the terms and conditions provided by Springer and Copyright Clearance Center.

License Number $\quad 3717780345240$

License date Sep 28, 2015

Licensed Content Publisher Springer

Licensed Content Publication Cardiovascular Toxicology

Licensed Content Title

Air Pollution-Induced Vascular Dysfunction: Potential Role of Endothelin-1 (ET-1) System

Licensed Content Author

Jordan Finch

Licensed Content Date

Jan 1, 2015

Type of Use

Thesis/Dissertation

Portion

Full text

Number of copies

5

Author of this Springer article Yes and you are a contributor of the new work

Order reference number None

Air Pollution, Pulmonary Oxidative Stress, and the

Title of your thesis / dissertation Endothelin System in the Development of Cardiovascular Disease

Expected completion date July 2016

Estimated size(pages) $\quad 130$

Jordan Finch

580 S. Preston Street

Requestor Location

LOUIS VILLE, KY 40202

United States

Attn: Jordan B Finch

Billing Type

Invoice

Jordan B Finch

580 S. Preston Street

Billing Address

LOUISVILLE, KY 40202

United States

Attn: Jordan B Finch 
CURRICULUM VITAE

\author{
Jordan B. Finch \\ University of Louisville School of Medicine \\ Department of Pharmacology and Toxicology \\ Louisville, KY, 40202 \\ jbfinc01@louisville.edu
}

\title{
EDUCATION
}

2013-Present University of Louisville

M.S. Pharmacology \& Toxicology, In progress

2011-2013 Southern Illinois University Edwardsville

M.S. Biological Sciences

2007-2011 McKendree University

B.S. Biology, Minors in Chemistry and Biochemistry

\section{$\underline{\text { HONORS }}$}

2013-2015 University of Louisville Integrated Programs in Biomedical Science Graduate Research Fellowship

2013 Illinois State Academy of Science Poster Competition, First Place in Environmental Health

2012 Southern Illinois University Edwardsville Research Grant for Graduate Students

2011 McKendree University Honors Program

2011 McKendree University Magna Cum Laude 
2011 McKendree University Biology Department Top Student Award

2009-2011 McKendree University Dean's List

2009-2011 McKendree University Carrie Field Smith and Emma Lee Foree Walkup Smith Memorial Scholarship

2009-2011 McKendree University Edwin P. Baker Scholarship

2007-2011 McKendree University Founder's Scholarship

2007-2011 McKendree University Dance Team Scholarship

2007-2008 McKendree University President's List

\section{LEADERSHIP}

2009-2011 Sigma Zeta National Science \& Mathematics Honor Society Beta Chapter Vice President

2010-2011 McKendree University Dance Team Captain

\section{TEACHING RELATED EXPERIENCE}

2009-2011 McKendree University Academic Tutor: Biology, Anatomy and Physiology, Organic Chemistry, and Statistics

2009 Boy Scouts of America Ecology Teacher: Insect Study and Nature Merit Badges

\section{PROFESSIONAL SOCIETIES}

2013 Phi Kappa Phi Honor Society

2012-2013 Illinois State Academy of Science

2008-2011 Sigma Zeta National Science and Mathematics Honor Society

\section{PUBLICATIONS}

Finch, J. \& Conklin, D. (2016). Air Pollution-Induced Vascular Dysfunction:

Potential Role of Endothelin-1 (ET-1) System. Cardiovascular Toxicology, 16(3): 260-275. 


\section{Oral Presentations}

What to Do With a Dead Body: A Forensic Evaluation of Skeletal Remains. Sigma Zeta

National Science and Mathematics Honor Society 82nd National Convention, San Antonio, TX, 2011

\section{Poster Presentations}

Jordan Finch, Petra Haberzettl, Aruni Bhatnagar, Daniel J. Conklin. Air Pollution, Pulmonary Oxidative Stress, and the Endothelin System in the Development of Cardiovascular Disease. University of Louisville Graduate Student Council Research Conference, Louisville, KY, 2016

Jordan Finch, Petra Haberzettl, Aruni Bhatnagar, Daniel J. Conklin. Air Pollution, Pulmonary Oxidative Stress, and the Endothelin System in the Development of Cardiovascular Disease. University of Louisville Research!Louisville, Louisville, KY, 2015

Jordan Finch, Timothy E. O'Toole, James McCracken, Natasha DeJarnett, Aruni Bhatnagar, C. Arden Pope III, Daniel J. Conklin. Air Pollution and Biomarkers of Cardiovascular Injury -- Endothelin-1 and Endothelial Progenitor Cells in Humans. University of Louisville, Cardiovascular Innovation Institute Vascular Research Day, Louisville, KY 2015

Jordan Finch, Timothy E. O'Toole, James McCracken, Natasha DeJarnett, Aruni Bhatnagar, C. Arden Pope III, Daniel J. Conklin. Air Pollution and Biomarkers of Cardiovascular Injury -- Endothelin-1 and Endothelial Progenitor Cells in Humans. University of Louisville, Research!Louisville, Louisville, KY, 2014

Jordan Finch, Kurt Schulz, Richard Brugam, Zhi-Qing Lin, Luci Kohn. A Study in Lead: An Analysis of Human Lead Exposure in the Old Lead Belt of Southeastern Missouri. Illinois State Academy of Science 105th Annual Meeting, Jacksonville, IL, 2013

Abstracts

Natasha DeJarnett, Ray Yeager, Daniel Conklin, Timothy O’Toole, James McCracken, Wesley Abplanalp, Daniel Riggs, Ihab Hamzeh, Stephen Wagner, Atul Chugh, Andrew DeFilippis, Tiffany Ciszewski, Bradley Wyatt, Carrie Becher, Deirdre Hidgon, Jordan Finch, Imtiaz Ismail, David J. Tollerud, Shesh Rai, Jasmit Shah, Nagma Zafar, Stahya Krishmasamy, Sumanth Prabhu, Aruni Bhatnagar. Air Pollution and Tobacco Smoke Differentially Depress Circulating Angiogenic 
Cells in Humans. American Public Health Association Annual Meeting, Chicago, IL, 2015. 